\title{
\#USES
}

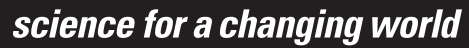

Prepared in cooperation with the Department of Interior South-Central Climate Science Center

\section{Historical and Projected Climate (1901-2050) and Hydrologic Response of Karst Aquifers, and Species Vulnerability in South-Central Texas and Western South Dakota}
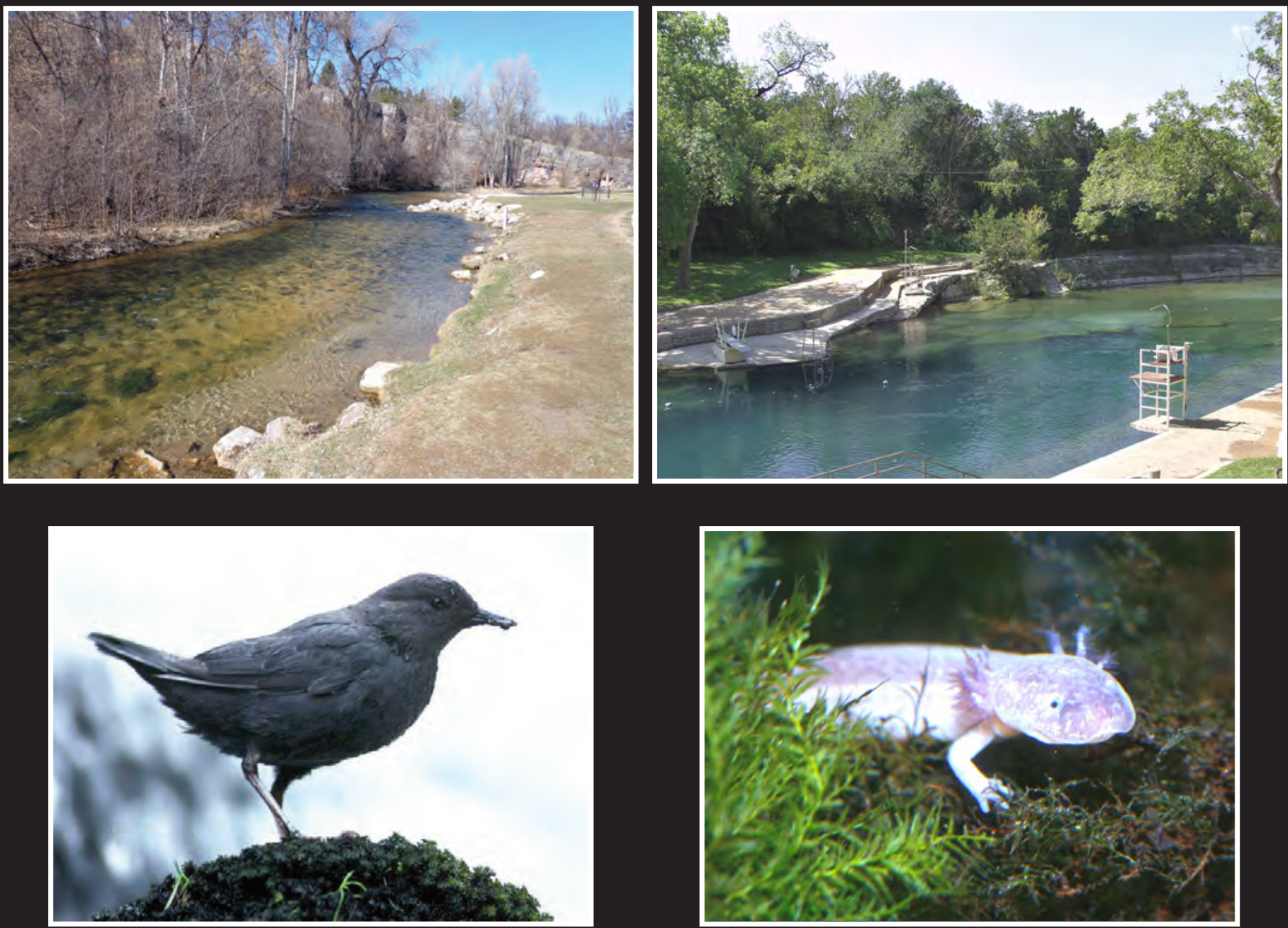

Scientific Investigations Report 2014-5089 
Cover photographs. Upper left, Downstream view of Spearfish Creek at Spearfish, South Dakota. Photograph by Louis Leader Charge, U.S. Geological Survey. Upper right, Barton Springs pool, Austin, Texas. The spring discharges from beneath the limestone ledges, visible at the upper end of the pool. Photograph by David Johns, City of Austin, Texas. Bottom right, Barton Springs salamander. Photograph by Lisa O'Donnell, City of Austin, Texas. Bottom left, American dipper. Photograph by Dave Menke, U.S. Fish and Wildlife Service. 


\section{Historical and Projected Climate (1901- 2050) and Hydrologic Response of Karst Aquifers, and Species Vulnerability in South-Central Texas and Western South Dakota}

By John F. Stamm, Mary F. Poteet, Amy J. Symstad, MaryLynn Musgrove, Andrew J. Long, Barbara J. Mahler, and Parker A. Norton

Prepared in cooperation with the Department of Interior South-Central Climate Science Center

Scientific Investigations Report 2014-5089 


\title{
U.S. Department of the Interior SALLY JEWELL, Secretary
}

\section{U.S. Geological Survey \\ Suzette M. Kimball, Acting Director}

\author{
U.S. Geological Survey, Reston, Virginia: 2015
}

For more information on the USGS - the Federal source for science about the Earth, its natural and living resources, natural hazards, and the environment, visit http://www.usgs.gov or call 1-888-ASK-USGS.

For an overview of USGS information products, including maps, imagery, and publications, visit http://www.usgs.gov/pubprod

To order this and other USGS information products, visit http://store.usgs.gov

Any use of trade, firm, or product names is for descriptive purposes only and does not imply endorsement by the U.S. Government.

Although this information product, for the most part, is in the public domain, it also may contain copyrighted materials as noted in the text. Permission to reproduce copyrighted items must be secured from the copyright owner.

Suggested citation:

Stamm, J.F., Poteet, M.F., Symstad, A.J., Musgrove, MaryLynn, Long, A.J., Mahler, B.J., and Norton, P.A., 2015, Historical and projected climate (1901-2050) and hydrologic response of karst aquifers, and species vulnerability in south-central Texas and western South Dakota: U.S. Geological Survey Scientific Investigations Report 2014-5089, 59 p., plus supplements, http://dx.doi.org/10.3133/sir20145089.

ISSN 2328-0328 (online) 


\section{Contents}

Acknowledgments .........................................................................................................................ii

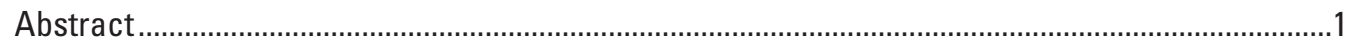

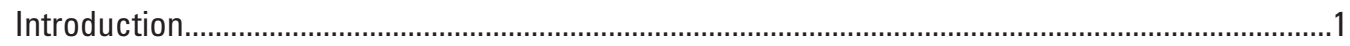

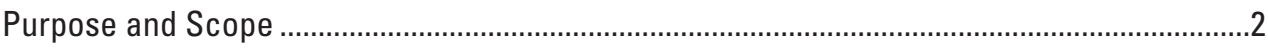

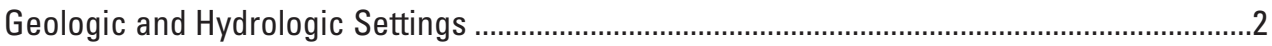

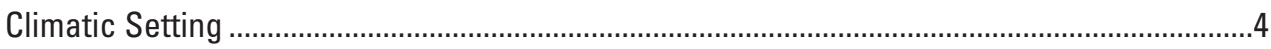

Historical Climate

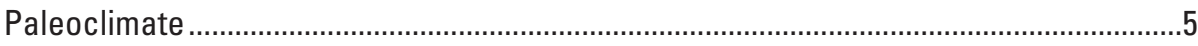

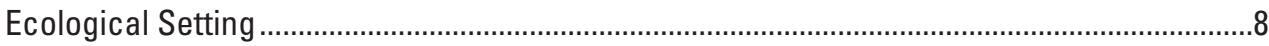

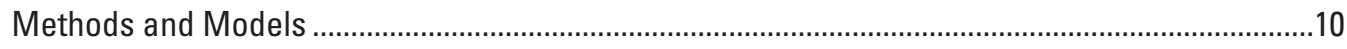

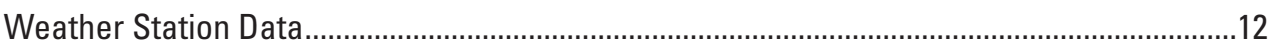

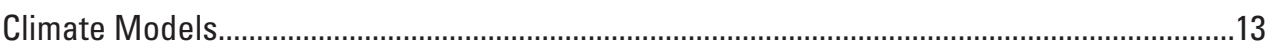

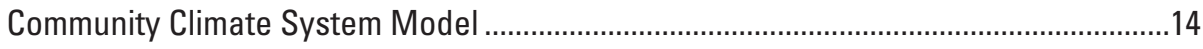

Weather Research and Forecasting Model ..............................................................15

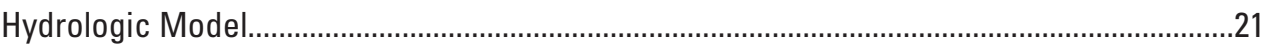

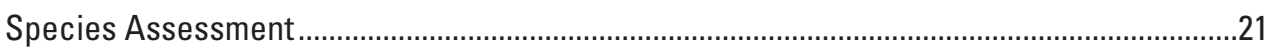

Historical and Projected Climate and Hydrologic Response ........................................................

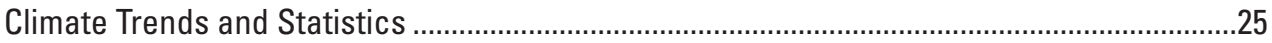

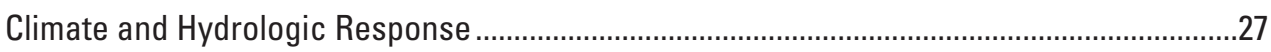

Baseline and Projected Climate and Hydrologic Response .................................................29

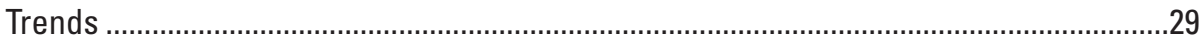

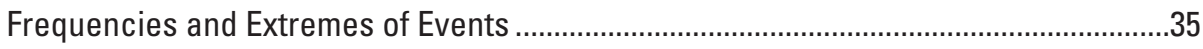

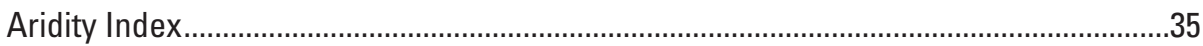

Species Vulnerability to Projected Climate and Hydrologic Response ............................................38

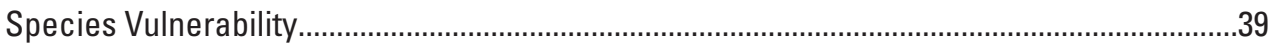

Differences Between Regions.............................................................................................46

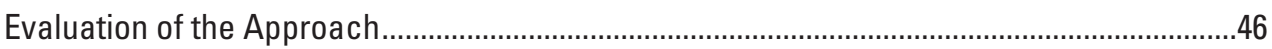

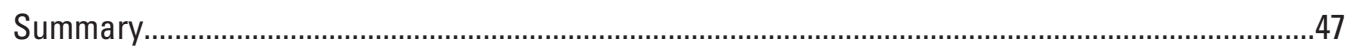

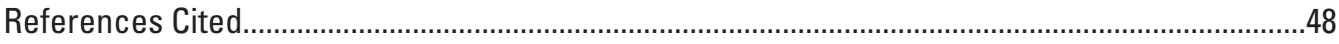

Supplement 1. Data Tables for Species Vulnerability Assessment...................................................60

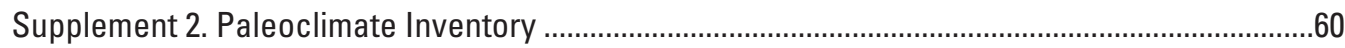

Supplement 3. Weather Research and Forecasting Model Namelist Files and Bias

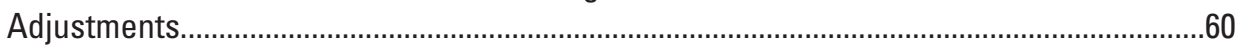




\section{Figures}

1. Map showing study area and locations of weather stations, streamgages, and wells used in the analyses and models

2. Isohyetal and isothermal maps for the regions of the Balcones Escarpment and Black Hills, based on annual values computed from output from the Parameter-elevation Regressions on Independent Slopes Model averaged for 1901-2000

3. Graph showing concentrations of greenhouse gases on the basis of the Vostok ice core, and current and projected concentrations.

4. Map showing ecoregions and land cover of Edwards aquifer sites and the surrounding region

5. Map showing ecoregions and land cover of Madison aquifer sites and the surrounding region...

6. Diagram showing linkage of model components 12

7. Graphs showing time series of annual mean surface air temperature and total precipitation during 1901-2099 for the area of the Great Plains for three general circulation models, and during 1901-2012 for the Parameter-elevation Regressions on Independent Slopes Model.

8. Graphs showing mean monthly surface air temperature and total precipitation during 1901-2012 for the area of the Great Plains for three general circulation models and for the Parameter-elevation Regressions on Independent Slopes Model.

9. Map showing the Weather Research and Forecasting model domain extent showing land-surface altitudes at the 36-kilometer resolution.

10. Graphs showing time series of annual mean surface air temperature and total precipitation for the area of the Great Plains from the Community Climate System Model, version 3, two simulations from the Weather Research and Forecasting model, and the Parameter-elevation Regressions on Independent Slopes Model.

11. Graphs showing annual total precipitation, annual mean daily air temperatures, and 10-year moving means of annual values of weather station records and adjusted output from the Weather Research and Forecasting Model for selected weather stations

12. Graphs showing mean monthly precipitation and air temperature of weather station records and adjusted output from the Weather Research and Forecasting model for selected weather stations.

13. Graphs showing annual mean air temperature, annual total precipitation, and annual mean springflow or water-table level for Edwards and Madison aquifer sites based on observed weather station records, output from the Weather Research and Forecasting model, and output from the Rainfall-Response Aquifer and Watershed Flow model

14. Graph showing number of days and consecutive days in a year that the maximum daily air temperature exceeded 36 degrees Celsius at the Lead, South Dakota, weather station

15. Graph showing aridity index for start of records through 2050 for selected weather stations. 


\section{Tables}

1. Weather stations used to synthesize climate records for the five Rainfall-Response Aquifer and Watershed Flow model sites and weather station period of records

2. Description and location for weather stations used to quantify climate variability .......13

3. Dynamical mesoscale models for North American climate and associated Atmosphere-0cean General Circulation Model.

4. General description of physics schemes used in the Weather Research and Forecasting model

5. Factors scored in the Climate Change Vulnerability Index and climate and hydrologic input used for scoring.....

6. Mean annual precipitation and air temperature for years 1943-2050, 1943-2010, and 2011-50 for selected weather stations.

7. Results of Kendall-tau nonparametric test of significance of trends for records and climate projections for selected weather stations

8. Anomalies of climate variables for selected weather stations

9. Statistical significance and direction of trends in monthly and annual precipitation and air temperatures at selected weather stations for the period spanning the start of weather station records through 1975

10. Statistical significance and direction of trends in projected monthly and annual precipitation and air temperatures at selected weather stations for 2011-50

11. Statistical significance and direction of trends in monthly and annual precipitation and air temperatures at selected weather stations for the period spanning the start of the weather station record through 2050

12. Climate anomalies, computed as mean monthly or mean annual for 2041-50 minus mean monthly or mean annual for start of record through 1975 at selected weather stations.

13. Statistical significance and direction of trends in monthly mean and annual mean springflow or water-table level at Edwards and Madison aquifer sites based on output from the Rainfall-Response Aquifer and Watershed Flow model.

14. Exceedance values of daily climate variables for selected weather stations, on the basis of observational records for the start of record through 1975 and output from the Weather Research and Forecasting model for 2041-50

15. Exceedance values of simulated daily springflow or water-table level for Edwards and Madison aquifer sites based on output from Rainfall-Response Aquifer and Watershed Flow model for the start of record through 1975 and for 2041-50....

16. Range in annual temperature measured as July mean daily maximum air temperature minus January mean daily minimum air temperature for start of weather station record (SOR) through 1975 for selected weather stations

17. Percentage of years in listed time periods of aridity index classifications for weather stations for three periods: start of weather station record to 1975, 2041-50, and SOR-2050

18. Climate change vulnerability, confidence in that assessment, and vulnerability to other anthropogenic threats for selected karst-hydrology-dependent species in the Balcones Escarpment and Black Hills regions.....

19. Climate and hydrologic input for factors in the Climate Change Vulnerability Index for each weather station/hydrologic site..... 


\section{Supplement Tables}

S1-1. Species of conservation concern that depend strongly on karst hydrology in the Balcones Escarpment and Black Hills regions, their conservation status and restriction to the assessment area, and whether their vulnerability to climate change was scored for this report

S1-2. Climate Change Vulnerability Index factor scores, information supporting those scores, and the CCVI results for select karst-hydrology-dependent species in the Balcones Escarpment and Black Hills regions

S2-1. Review and inventory of local and regional paleoclimatic studies with relevance for the study areas.

S3-1. Bias corrections applied to the Weather Research and Forecasting Model output interpolated to the locations of weather stations for modeled sites 


\section{Conversion Factors}

SI to Inch/Pound

\begin{tabular}{lcl}
\hline \multicolumn{1}{c}{ Multiply } & By & \multicolumn{1}{c}{ To obtain } \\
\hline millimeter $(\mathrm{mm})$ & Length & \\
meter $(\mathrm{m})$ & 0.03937 & inch (in.) \\
kilometer $(\mathrm{km})$ & 3.281 & foot (ft) \\
kilometer $(\mathrm{km})$ & 0.6214 & mile (mi) \\
meter $(\mathrm{m})$ & 0.5400 & mile, nautical (nmi) \\
& 1.094 & yard (yd) \\
\hline cubic meter per second $\left(\mathrm{m}^{3} / \mathrm{s}\right)$ & Flow rate & gallon per minute $(\mathrm{gal} / \mathrm{min})$ \\
\hline
\end{tabular}

Temperature in degrees Celsius $\left({ }^{\circ} \mathrm{C}\right)$ may be converted to degrees Fahrenheit $\left({ }^{\circ} \mathrm{F}\right)$ as follows:

${ }^{\circ} \mathrm{F}=\left(1.8 x^{\circ} \mathrm{C}\right)+32$

Vertical coordinate information is referenced to the North American Vertical Datum of 1988 (NAVD 88).

Horizontal coordinate information is referenced to the North American Datum of 1983 (NAD 83).

Altitude, as used in this report, refers to distance above the vertical datum.

Water year is the 12-month period, October 1 through September 30, and is designated by the calendar year in which it ends.

Concentrations of chemical constituents in water are given in milligrams per liter (mg/L). 


\section{Abbreviations}

\begin{tabular}{ll}
$\sim$ & approximately \\
$\leq$ & less than or equal to \\
20C3M & 20th Century Climate in Coupled Models \\
AOGCM & Atmosphere-Ocean General Circulation Model \\
CCSM3 & Community Climate System Model, version 3.0 \\
CCVI & Climate Change Vulnerability Index \\
CGCM3 & Canadian Centre for Climate Modeling and Analysis General Circulation \\
CO & Model, version 3.1/T63 \\
$E_{\mathrm{N}-\mathrm{S}}$ & carbon dioxide \\
GFDL CM2 & Nash-Sutcliffe coefficient of efficiency \\
IRF & Geophysical Fluid Dynamics Laboratory Climate Model, version 2.1 \\
Ma & impulse-response function \\
NOAA & million years ago \\
$P$ & National Oceanic and Atmospheric Administration \\
$p$-value & precipitation \\
PAGES 2k & probability value \\
ppb & Past Global Changes research on the last 2,000 years \\
ppmv & parts per billion \\
PRISM & parts per million by volume \\
RegCM & Parameter-elevation Regressions on Independent Slopes Model \\
RRAWFLOW & Regional Climate Model \\
SOR & Rainfall-Response Aquifer and Watershed Flow \\
SRES & start of record \\
$T_{\text {max }}$ & Special Report on Emission Scenarios \\
$T_{\text {mean }}$ & meaximum air temperature \\
$T_{\text {min }}$ & mean air temperature \\
WPS & minimum air temperature \\
WRF & Weather Research and Forecasting (WRF) model Preprocessing System \\
YBP & Wesearch and Forecasting \\
\hline
\end{tabular}

\section{Acknowledgments}

This study was supported by the Department of Interior South-Central Climate Science Center. 


\title{
Historical and Projected Climate (1901-2050) and Hydrologic Response of Karst Aquifers, and Species Vulnerability in South-Central Texas and Western South Dakota
}

\author{
By John F. Stamm, ${ }^{1}$ Mary F. Poteet,${ }^{2}$ Amy J. Symstad, ${ }^{1}$ MaryLynn Musgrove, ${ }^{1}$ Andrew J. Long, ${ }^{1}$ \\ Barbara J. Mahler, ${ }^{1}$ and Parker A. Norton ${ }^{1}$
}

\section{Abstract}

Two karst aquifers, the Edwards aquifer in the Balcones Escarpment region of south-central Texas and the Madison aquifer in the Black Hills of western South Dakota, were evaluated for hydrologic response to projected climate change through 2050. Edwards aquifer sites include Barton Springs, the Bexar County Index Well, and Comal Springs. Madison aquifer sites include Spearfish Creek and Rhoads Fork Spring. Climate projections at sites were based on output from the Community Climate System Model of global climate, linked to the Weather Research and Forecasting (WRF) model of regional climate. The WRF model output was bias adjusted to match means for 1981-2010 from records at weather stations near Madison and Edwards aquifer sites, including Boerne, Texas, and Custer and Lead, South Dakota. Hydrologic response at spring and well sites was based on the Rainfall-Response Aquifer and Watershed Flow (RRAWFLOW) model. The WRF model climate projections for 2011-50 indicate a significant upward trend in annual air temperature for all three weather stations and a significant downward trend in annual precipitation for the Boerne weather station. Annual springflow simulated by the RRAWFLOW model had a significant downward trend for Edwards aquifer sites and no trend for Madison aquifer sites.

Flora and fauna that rely on springflow from Edwards and Madison aquifer sites were assessed for vulnerability to projected climate change on the basis of the Climate Change Vulnerability Index (CCVI). The CCVI is determined by the exposure of a species to climate, the sensitivity of the species, and the ability of the species to cope with climate change. Sixteen species associated with springs and groundwater were assessed in the Balcones Escarpment region. The Barton Springs salamander (Eurycea sosorum) was scored as highly vulnerable with moderate confidence. Nine species - three

\footnotetext{
${ }^{1}$ U.S. Geological Survey.
}

${ }^{2}$ University of Texas, Austin. salamanders, a fountain darter (Etheostoma fonticola), three insects, and two amphipods - were scored as moderately vulnerable. The remaining six species-four vascular plants, the Barton cavesnail (Stygopyrgus bartonensis), and a cave shrimp - were scored as not vulnerable/presumed stable (not vulnerable and evidence does not support change in abundance or range of the species). Vulnerability of eight species associated with streams that receive springflow from the Madison aquifer in the Black Hills was assessed. Of these, the American dipper (Cinclus mexicanus) and the lesser yellow lady's slipper (Cypripedium parviflorum) were scored as moderately vulernable with high confidence. The dwarf scouringrush (Equisetum scirpoides) and autumn willow (Salix serissima) were also scored as moderately vulnerable with moderate to low confidence, respectively. Other species were assessed as not vulnerable/presumed stable or not vulnerable/increase likely (not vulnerable and evidence supporting an increase in abundance or range of the species). Lower vulnerability scores for the Black Hills species in comparison to the Balcones Escarpment species reflect lower endemicity, higher projected springflow than in the historical period, and high thermal tolerance of many of the species for the Black Hills. Importantly, climate change vulnerability scores differed substantially for Edwards aquifer species when RRAWFLOW model projections were included, resulting in increased vulnerability scores for 12 of the 16 species.

\section{Introduction}

Karst aquifers are important groundwater resources in North America (Brahana and others, 1988; Johnston, 1997). Karst aquifers are characterized by appreciable flow along joints, faults, bedding planes, and solution cavities (Palmer, 1990), and can exhibit large short-term variability in hydrogeologic characteristics, such as springflow and water-table level (Brahana and others, 1988; Fetter, 2001). As a result, karst aquifers are likely to respond rapidly to climate change 
(Ma and others, 2004; Long and Mahler, 2013), particularly in areas where urban development imparts additional stresses to the system (Loáiciga and others, 1996, 2000; Sharp and Banner, 1997). Furthermore, many biological communities and ecosystems associated with karst aquifers and terranes also are extremely sensitive to changes in hydrologic conditions (Hardwick and Gunn, 1993; Sharp and Banner, 1997; Graening and Brown, 2003). Fifty percent of North American imperiled species live in subterranean habitats, many of which are associated with karst aquifers and terranes (Culver and others, 2000).

Response of karst aquifers and associated ecosystems to projected climate change through 2050, based on the A2 emission scenario (Nakićenović and Swart, 2000), were examined at sites within two regions of karst terrane: the Balcones Escarpment of south-central Texas and the Black Hills of western South Dakota (fig. 1). The underlying karst aquifers in these two regions are the Edwards Balcones Fault Zone aquifer (hereinafter the Edwards aquifer) and the Madison aquifer, respectively. Examined sites in these two regions are referred to as Edwards and Madison aquifer sites. Municipalities in both regions, and State parks and national forests and parks in the Black Hills, rely on water resources from these aquifers (Sharp and Banner, 1997; Carter and others, 2002). The associated ecosystems support federally listed endangered and threatened species (Sharp and Banner, 1997; Edwards Aquifer Research and Data Center, 2012) and numerous Statelisted species of concern (Larson and Johnson, 2007) (species are listed in supplemental table S1-1).

Vulnerability of species to projected climate change was assessed using the Climate Change Vulnerability Index (CCVI) (Young and others, 2012). The CCVI uses historical and projected climate, springflow, and, if available, watertable level to determine the vulnerability of selected species to climate and associated hydrogeologic change (factors used to estimate vulnerability of selected species are listed in supplemental table S1-2). Projected climate through 2050 was simulated using the Community Climate System Model, version 3.0 (CCSM3) (Collins and others, 2004), of global climate linked to the Weather Research and Forecasting (WRF) model (Skamarock and others, 2008) of regional climate. Response of springflow or water-table level to historical and projected climate factors was simulated using the Rainfall-Response Aquifer and Watershed Flow (RRAWFLOW) model (Long and Mahler, 2013). Once linked, the CCSM3, WRF model, RRAWFLOW model, and CCVI together provide a bridge to project the effects of global climate change on local karst aquifers and springs, and reliant species.

\section{Purpose and Scope}

The purpose of this report is to describe the effects of historical and projected climate (1901-2050) and hydrologic response of karst aquifers and species vulnerability in southcentral Texas and western South Dakota. The methodology used to assess species vulnerability at Edwards and Madison aquifer sites based on models that operate at scales ranging from global (CCSM3), to regional (WRF model), to local (RRAWFLOW model) scales is described. Sensitivity of the methodology and application on the basis of multiple climate models and multiple emission scenarios is beyond the scope of this report. The selection of climate models and the greenhouse-gas emission scenario is described. Factors that affect vulnerability of species to climate change and hydrologic response of karst aquifers are identified. The methodology described could be applied to karst regions elsewhere, or for species not included in this study.

\section{Geologic and Hydrologic Settings}

The geologic and hydrologic settings of the Balcones Escarpment of Texas and the Black Hills of South Dakota are characterized by plateaus of resistant carbonate rocks. The Balcones Escarpment is named for resistant rocks expressed by steps or "balconies" in the landscape, which rises from the Coastal Plain to the east of the Balcones Escarpment, to the higher altitudes of the Edwards Plateau (Fenneman, 1931), a resistant upland of nearly flat-lying Early Cretaceous-age limestone and dolostone, to the west (fig. 1). The regional geology and hydrology of south-central Texas and the area of the Balcones Escarpment, described in detail by Rose (1972), Abbott (1975), Abbott and Woodruff (1986), Barker and Ardis (1996), Sharp and Banner (1997), and Lindgren and others (2004), is summarized briefly in this section.

The Balcones Escarpment is the surface manifestation of the Balcones fault zone, which consists of a series of high-angle normal en echelon down-toward-the-coast faults that were active during the Miocene Epoch [24-5 million years ago (Ma)]. The Edwards aquifer, a karst aquifer that lies along the Balcones Escarpment, is part of the larger Edwards-Trinity aquifer system and is one of the most permeable and productive karst aquifers in the Nation (Barker and Ardis, 1996). For example, an artesian well in the Edwards aquifer has been reported as the world's greatest flowing well at 1.58 cubic meters per second $\left(\mathrm{m}^{3} / \mathrm{s}\right)(25,000$ gallons per minute) (Swanson, 1991). Watersheds to the west contribute most of the recharge to the aquifer (Burchett and others, 1986). Streams flowing south and east toward the Gulf of Mexico drain the Edwards Plateau and recharge the aquifer as they cross the Balcones fault zone. The Edwards aquifer is unconfined adjacent to and in the outcrop (recharge) zone and confined in down-dip parts of the Balcones fault zone. Regional groundwater flow is to the east and northeast, with natural discharge occurring at large springs, such as Barton Springs and Comal Springs (fig. 1).

The regional geologic setting of western South Dakota and the Black Hills has been summarized by Gries (1996) and Carter and others (2002), and described and mapped in detail for several studies (Darton, 1909; Darton and Paige, 1925; Dewitt and others, 1986; Martin and others, 2004; Redden and Dewitt, 2008). Precambrian-age igneous and metamorphic 


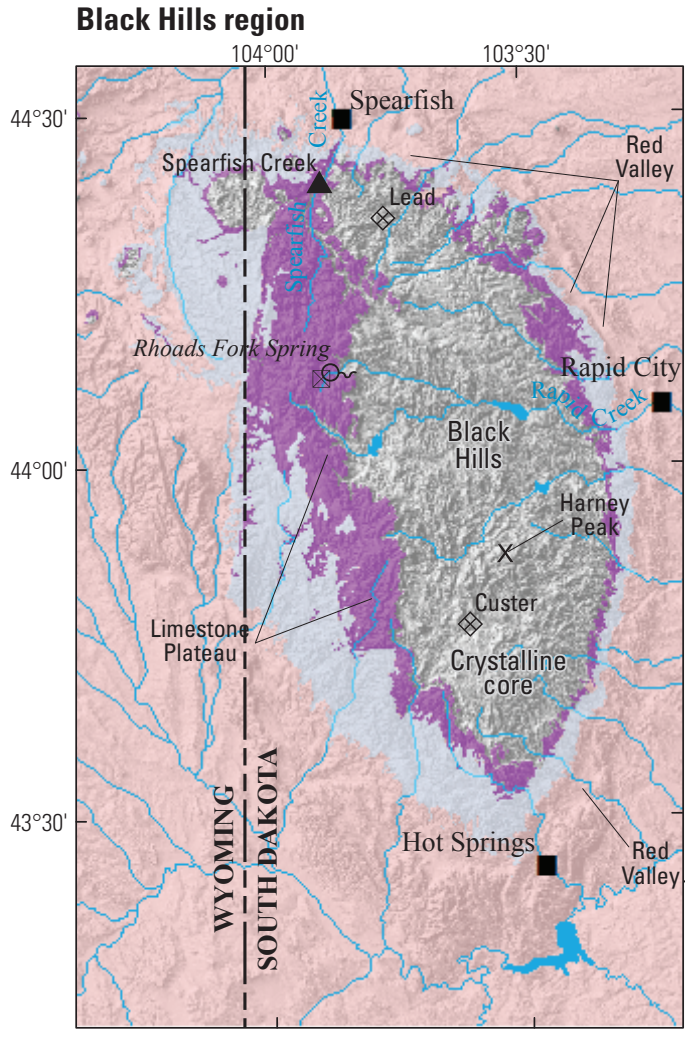

Transverse Mercator, North American Datum 1983 Elevation dataset: National Elevation Dataset (Gesch and others, 2002; Gesch, 2007)

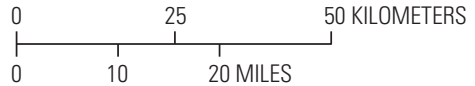

Balcones Escarpment region

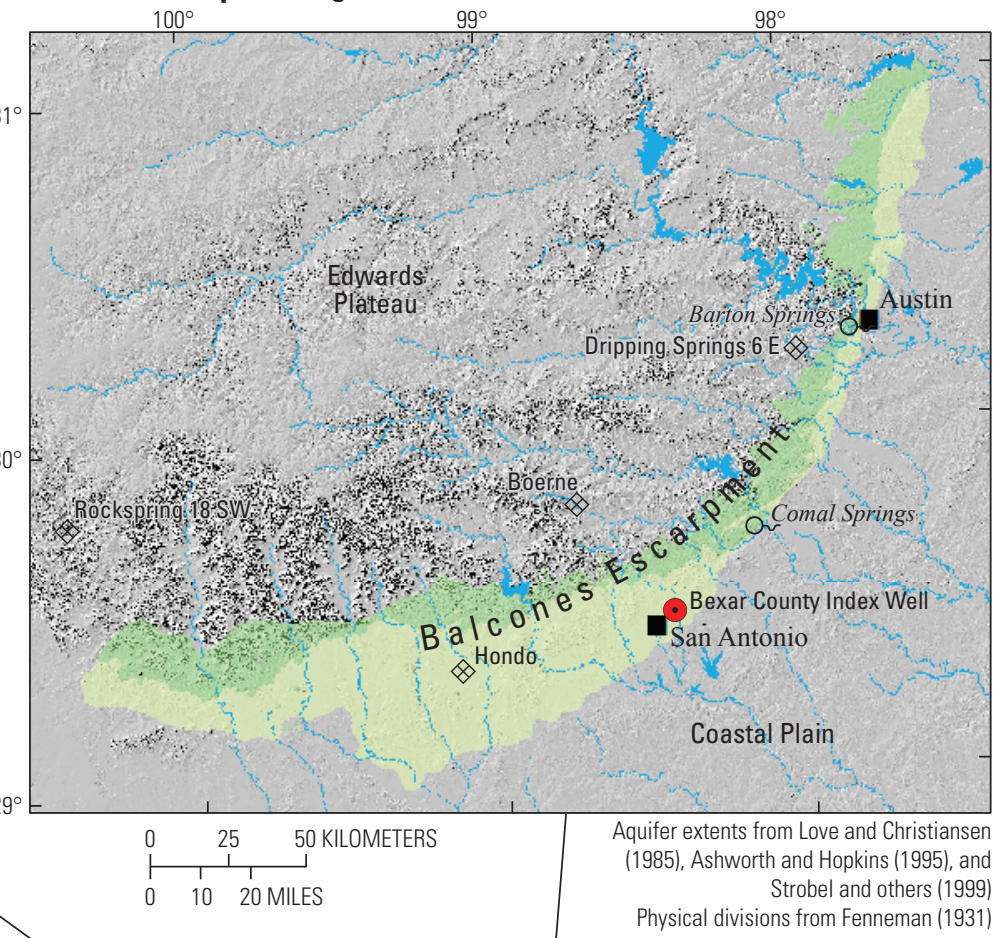

\section{EXPLANATION}

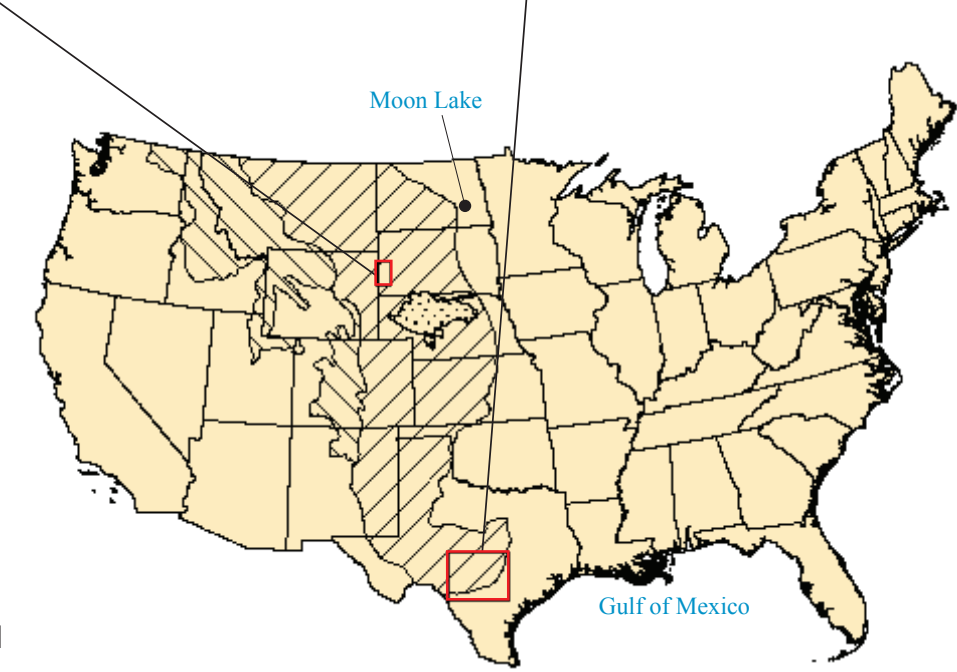

\section{Hydrogeologic unit}

Edwards aquifer surface-recharge area

Edwards aquifer below land surface (confined)

Madison aquifer surface-recharge area

Madison aquifer below land surface (confined)

Spearfish Creek Streamgage and identifier

Comal Springs or Spring or spring complex and identifier

Bexar County Index Well Well and identifier

${ }^{H o n d o} \otimes$ Weather station and identifier

$\triangle$ Centroid for interpolation of weather

records

Minnelusa aquifer surface-recharge area

Physical division and ecoregion

Rocky Mountain system

Great Plains province

Nebraska Sand Hills ecoregion

Figure 1. Study area and locations of weather stations, streamgages, and wells used in the analyses and models. Physical divisions and ecoregions relevant to the study area are labeled. 
rocks are exposed in the Central Basin of the Black Hills (Fenneman, 1931), a Laramide uplift that rises from the Great Plains to a maximum altitude of 2,208 meters (m) above North American Vertical Datum of 1988 (NAVD 88) at Harney Peak (fig. 1). The Laramide orogeny began approximately 65-63 Ma and ended about 55-43 Ma (Lisenbee and DeWitt, 1993). The Central Basin, also known as the crystalline core, is encircled by a layered series of Paleozoic and Mesozoic sedimentary rocks, which include the resistant Mississippianage Madison Limestone (locally referred to as the Pahasapa Limestone) and the overlying Pennsylvanian- and Permianage Minnelusa Formation, that typically dip away from the uplifted Black Hills. The Limestone Plateau is located on the western side of the Black Hills along the South Dakota and Wyoming border, where large outcrops of the Madison Limestone and Minnelusa Formation occur in a high-altitude area of generally low relief (Carter and others, 2002). The Black Hills are encircled by the lower elevations of the Red Valley, which is underlain by red clastic rocks of the Triassic-age Spearfish Formation and Jurassic-age Sundance Formation and other units. The foothills of the Black Hills are underlain by the steeply dipping Cretaceous-age Lakota Formation, which creates a prominent hogback that stands hundreds of meters above the surrounding plains and generally marks the boundary between the Black Hills and the plains (Gries, 1996). Less resistant Cretaceous-age marine deposits, such as the Pierre Shale, underlie the surrounding plains. Cenozoic sedimentary rocks unconformably overlie Cretaceous-age marine deposits and record the history of uplift and erosion of the Black Hills during and after the Laramide orogeny. Tertiary-age igneous units intruded primarily between 58 and $50 \mathrm{Ma}$ in the northern Black Hills (Lisenbee and DeWitt, 1993).

The regional hydrologic setting of the Black Hills includes the Madison aquifer, which is composed of Devonian-age Englewood Limestone and the Madison Limestone (Strobel and others, 1999). The characteristics of the Madison aquifer are described in detail by Carter and others (2002). The aquifer generally is within the upper karstic part of the Madison Limestone and saturated thickness is less than $60 \mathrm{~m}$ where the Madison Limestone is exposed at land surface. The aquifer is susceptible to drought conditions, particularly in areas where the Madison Limestone is exposed at land surface (Carter and others, 2002). Streams draining the crystalline core of the Black Hills generally provide more recharge to the Madison aquifer than the Minnelusa aquifer (fig. 1) because streams cross outcrops of the Madison Limestone before crossing outcrops of the Minnelusa Formation. Numerous springs occur along the eastern edge of the Limestone Plateau in incised channels near the base of the Madison Limestone, such as in the headwater area of Rapid Creek (fig. 1). Local groundwater-flow patterns are imposed on a regional flow pattern that has changed with time. Regional groundwaterflow directions were to the south during the maximum extent of the last glacial advance (approximately 21,000 years ago), and the current pattern of regional flow is to the east and northeast (Downey and Dinwiddie, 1988).

\section{Climatic Setting}

The climatic setting of the study area is described in this section in terms of the historical climatic settings of the Balcones Escarpment and the Black Hills regions, and in terms of the global and regional paleoclimatic setting. Historical climate (1901 to 2000) provides a baseline and context for current (2013) climate. Global paleoclimatic events provide a reference for the magnitude of current and projected concentrations of greenhouse gases in the next century.

\section{Historical Climate}

The climate of south-central Texas is subtropical, with a regional gradient from subhumid in the east to semi-arid in the west (Bomar, 1995). The dominant moisture source is the Gulf of Mexico, which is supplemented by winter precipitation from the west (Slade and Patton, 2003). The climate of south-central Texas is prone to extremes (Griffiths and Strauss, 1985). Droughts lasting from many months to years have been documented in the region since the earliest settlers began keeping records (Texas State Historical Association, 2013). The 1950s multiyear drought commonly is used as the worstcase scenario for water-resources planning, although the 2011 drought was the worst single-year drought recorded (NielsonGammon, 2011). Some of the most extreme 1-day duration storms in the world have occurred along the Balcones Escarpment, which can trigger high-intensity rain events (Slade, 1986).

The Black Hills region has a continental climate characterized by low precipitation, hot summers, cold winters, and extreme variability (Johnson, 1933). Orography affects climate with colder temperatures and higher precipitation at higher altitudes. The northern Black Hills is affected by moist air from the northwest, and the southern Black Hills is affected by drier air from the south-southeast. This produces a contrast in climate with mean precipitation ranging from 587 millimeters (mm) in the northern Black Hills to $415 \mathrm{~mm}$ in the southern Black Hills (water years 1931-98; Carter and others, 2002). The greatest amount of precipitation typically occurs during May and June (Driscoll and others, 2000; Driscoll and Carter, 2001). Extreme flash-flood events associated with thunderstorms occurred along the eastern flank of the Black Hills in summers of 1907, 1972, and 2007 (Schwarz and others, 1975; Driscoll and others, 2010; Harden and others, 2011). Periods of below normal precipitation occurred during 1931-40 ("Dust Bowl") and 1948-61; periods of above normal precipitation occurred during 1941-47, 1962-68, and 1991-98 (Driscoll and others, 2000), relative to the 1961-90 climate normal.

Spatial trends of historical climate of the Balcones Escarpment and Black Hills regions can be estimated on the basis of the Parameter-elevation Regressions on Independent Slopes Model (PRISM; Daly and others, 1994, 2002). The PRISM interpolates weather station observations of monthly total precipitation, and monthly mean of daily maximum air temperature and daily minimum air temperature to a 
2.5-arc-minute grid for the conterminous United States. Grids of PRISM output are generated for each year, extending back to 1895. The PRISM output averaged during 1901-2000 for grid points in the Balcones Escarpment region indicates a regional pattern of mean annual precipitation greater than $850 \mathrm{~mm}$ in the east decreasing to less than $500 \mathrm{~mm}$ in the west (fig. 2). Superimposed on the regional precipitation pattern is a pattern of highest precipitation along the Balcones Escarpment. Mean annual values of daily minimum and daily maximum air temperature have a spatial pattern of greatest air-temperature gradients along the Balcones Escarpment, reflecting the transition from the cooler Edwards Plateau relative to the warmer Coastal Plain. The PRISM grid points within the Edwards aquifer surface-recharge area (fig. 2) along the Balcones Escarpment have a mean annual precipitation value of $746 \mathrm{~mm}$, a mean annual maximum air temperature of 26.7 degrees Celsius $\left({ }^{\circ} \mathrm{C}\right)$, and a mean annual minimum air temperature of $13.1^{\circ} \mathrm{C}$.

The PRISM output averaged during 1901-2000 for grid points in the Black Hills region has a spatial pattern of increasing mean annual precipitation and decreasing mean annual air temperature with higher altitude than the surrounding plains such as along the Limestone Plateau (fig. 2). Mean annual precipitation in lower elevations surrounding the Black Hills is approximately 350 to $400 \mathrm{~mm}$, increasing with altitude to more than $750 \mathrm{~mm}$ in the northern Black Hills. Mean annual values of daily minimum and daily maximum air temperatures decrease with increasing altitude, with lowest mean annual temperatures in high altitude areas generally along the western side of the Black Hills. The PRISM grid points within the surface-recharge area for the Madison aquifer have a mean annual precipitation value of $591 \mathrm{~mm}$, and mean annual values of daily maximum and daily minimum air temperatures of $12.0^{\circ} \mathrm{C}$ and $-3.2{ }^{\circ} \mathrm{C}$, respectively. The surface-recharge area of Edwards aquifer along the Balcones Escarpment on average receives about $150 \mathrm{~mm}$ more annual precipitation than does the surface-recharge area of the Madison Limestone in the Black Hills and is about $15^{\circ} \mathrm{C}$ warmer.

\section{Paleoclimate}

Paleoclimatology is the study of climate before historical records (Bradley, 1999). Paleoclimatic conditions can be estimated from a variety of proxy sources including tree rings, ice cores, marine and lake sediments, and cave deposits (speleothems). In this report, paleoclimate variability is described to place the projected climate estimated for the upcoming decades into the context of natural variability. Selected studies relevant to the Edwards and Madison aquifer sites also are summarized. Proxy sources and paleoclimate relevant to the sites included in this study and of general interest for the central and western United States have been compiled in supplemental table S2-1.

It is generally accepted that global climate has cooled steadily since the beginning of the Tertiary Period (66 Ma) in response to a gradual trend of decreasing concentration of atmospheric carbon dioxide (Barron, 1985; Zachos and others, 2001; Solomon and others, 2007; Ruddiman, 2010). The Tertiary Period was marked by periods of warmth, some of which were punctuated events associated with elevated concentrations of carbon dioxide $\left(\mathrm{CO}_{2}\right)$ that might provide analogs to modern and projected climate trends (Kennett and Stott, 1991; Zachos and others, 2001). The atmospheric concentration of $\mathrm{CO}_{2}$ has not been as high as it is today [mean concentration surpassed 400 parts per million by volume (ppmv) in 2013 (National Oceanic and Atmospheric Administration, 2013)] since at least the mid-Pliocene Epoch, 3.3 to 3.0 Ma (Solomon and others, 2007). Some studies estimate that concentrations of atmospheric $\mathrm{CO}_{2}$ during the midPliocene Epoch were 360-400 ppmv and temperature was about $3.5^{\circ} \mathrm{C}$ warmer than the present (Raymo and Rau, 1992; Raymo and others, 1996). Tripati and others (2009) estimated $\mathrm{CO}_{2}$ concentrations of less than $350 \mathrm{ppmv}$ for 3.4 to $2.4 \mathrm{Ma}$, and their proxy estimators indicate $\mathrm{CO}_{2}$ concentrations did not reach modern concentrations near 400 ppmv until about $12 \mathrm{Ma}$. Estimates of the concentration of $\mathrm{CO}_{2}$ and methane during the late Quaternary can be determined from ice core records with relative accuracy (Petit and others, 1999), with greenhouse gas concentrations in ice core samples estimated at a temporal resolution of approximately 800 to 1,000 years. Present mean concentrations of greenhouse gases, including $\mathrm{CO}_{2}$ [approximately $(\sim) 393 \mathrm{ppmv}$ ] and methane $(\sim 1,800 \mathrm{ppb})$ (Blasing, 2013), exceed measurements from ice cores that extend back to about 420,000 years ago (fig. 3) during several glacial cycles, which each lasted about 100,000 years (Hays and others, 1976); however, the temporal resolution between ice core samples is much coarser than the time scale of recent increases in greenhouse gases during the past century.

Major glaciations in the northern hemisphere began about 2.6 Ma and marked the start of the Quaternary Period (Gibbard and others, 2009). Paleoclimate variability during the Quaternary Period was driven by variations in orbital forcing (Imbrie and others, 1984) and in the amount of incoming solar radiation to the atmosphere (Berger and Loutre, 1991). Changes in greenhouse gases amplified climate change (Petit and others, 1999), rather than being the primary driver for cycles. Warm interglacial periods during the Quaternary Period might act as analogs for projected climate predictions or provide insights to the vulnerability of ecosystems to global warming. In particular, the penultimate interglacial period, which occurred from about 130,000 to 116,000 years ago, was likely to have been warmer than the present interglacial by as much as $3{ }^{\circ} \mathrm{C}$ with less ice cover than today (Kukla and others, 2002).

During the past 2,000 years, all continental areas have had a significant long-term cooling trend of between $\sim 0.1$ and $0.3{ }^{\circ} \mathrm{C}$ per thousand years followed by warming during the 20th century (except in Antarctica, which does not exhibit 20th century warming) [Past Global Changes (PAGES) 2k Consortium, 2013]. Superimposed upon this cooling trend, Northern Hemisphere climate was marked by relatively warm conditions of the Medieval Climate Anomaly (also known as the Medieval Warm Period) from 950 to 1250 , which was 
Black Hills region

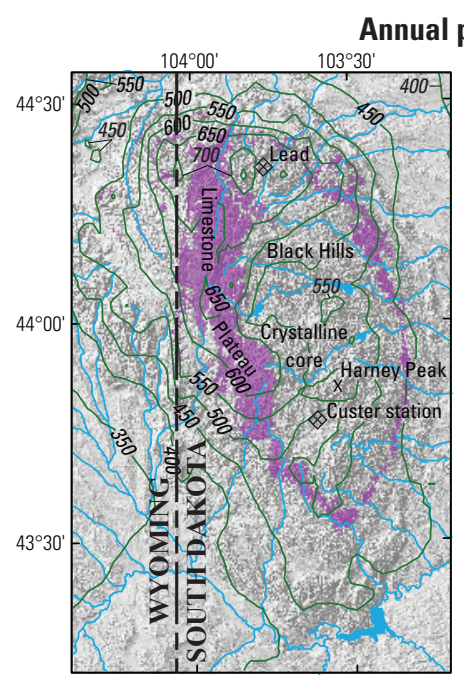

Balcones Escarpment region

\section{precipitation}
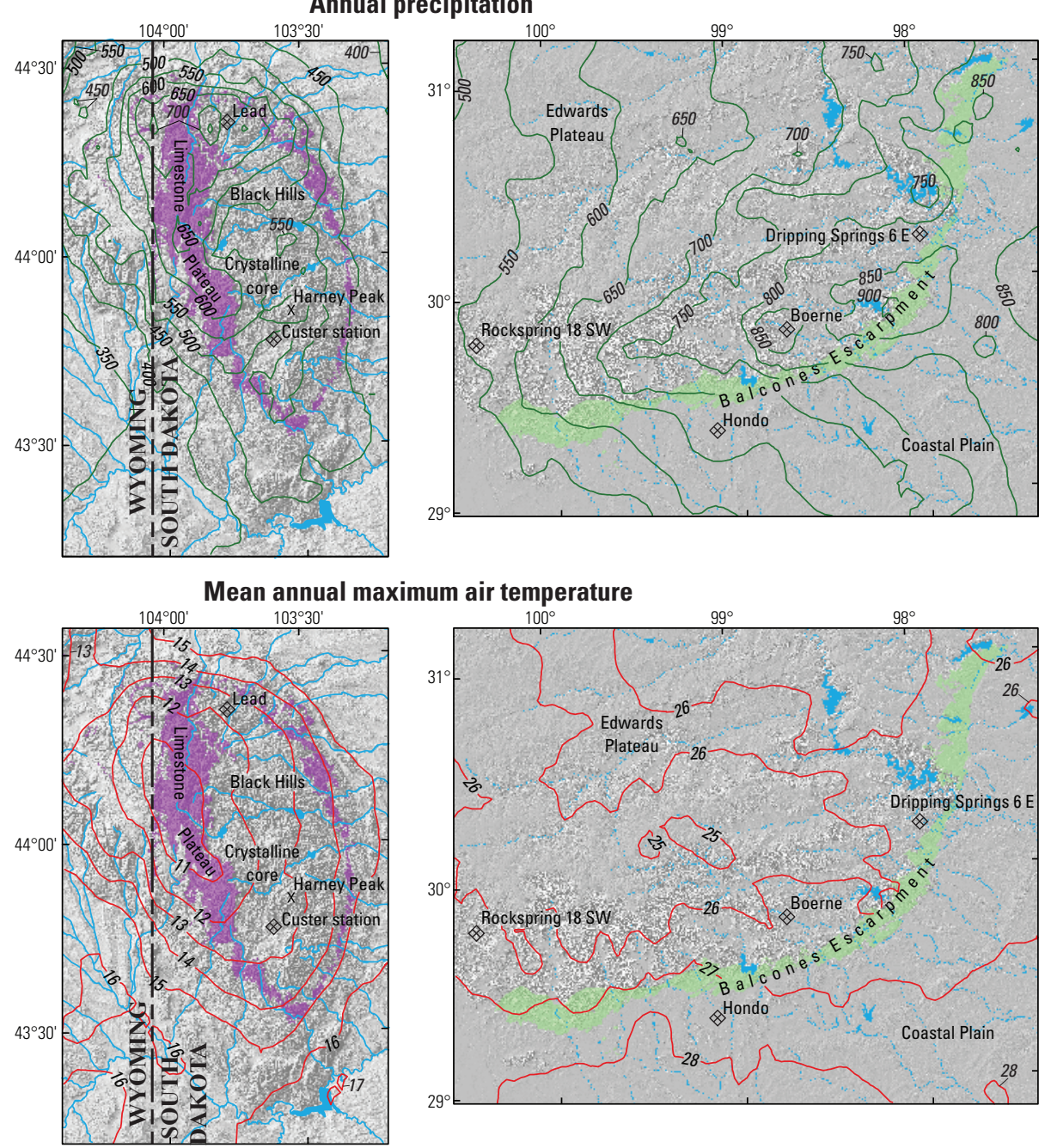

\section{mum air temperature}
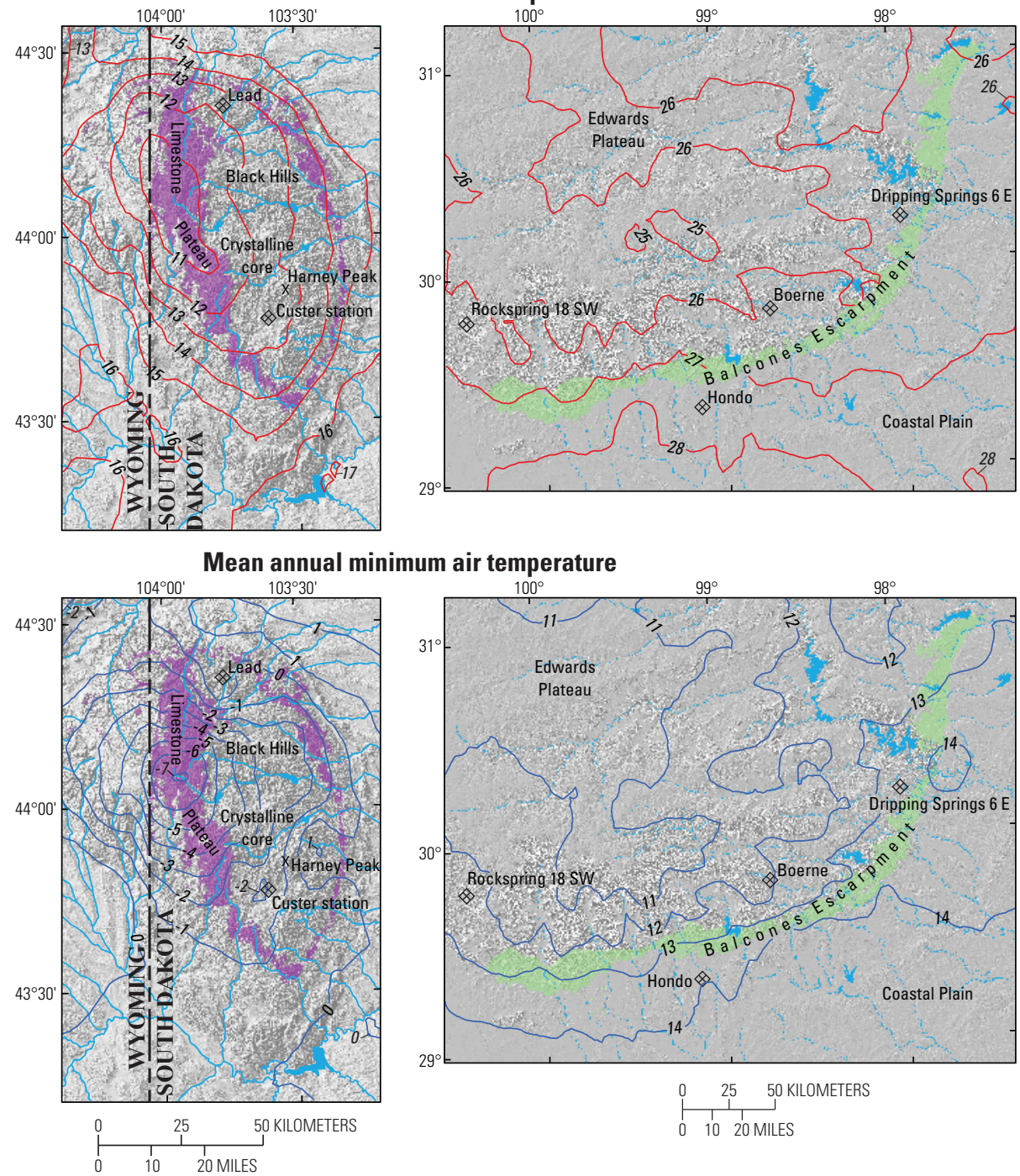

\section{EXPLANATION}

Hydrogeologic unit

Edwards aquifer surface-recharge area

Madison aquifer surface-recharge area

- 850 - Isohyet of annual precipitation-Interval 50 millimeters

-26 - Isotherm of mean annual maximum air temperature-Interval 1 degree Celsius

-13 - Isotherm of mean annual minimum air temperature-Interval 1 degree Celsius

Hondo $\otimes$ Weather station and identifier

Transverse Mercator, North American Datum 1983,

Elevation dataset: National Elevation Dataset

(Gesch and others, 2002; Gesch, 2007)

Isohyets: contours of Parameter-elevation Regressions on Independent Slopes Model Output,

http://www.prism.oregonstate.edu
Figure 2. Isohyetal and isothermal maps for the regions of the Balcones Escarpment and Black Hills, based on annual values computed from output from the Parameter-elevation Regressions on Independent Slopes Model (PRISM) (Daly and others, 1994, 2002) averaged for 1901-2000. 


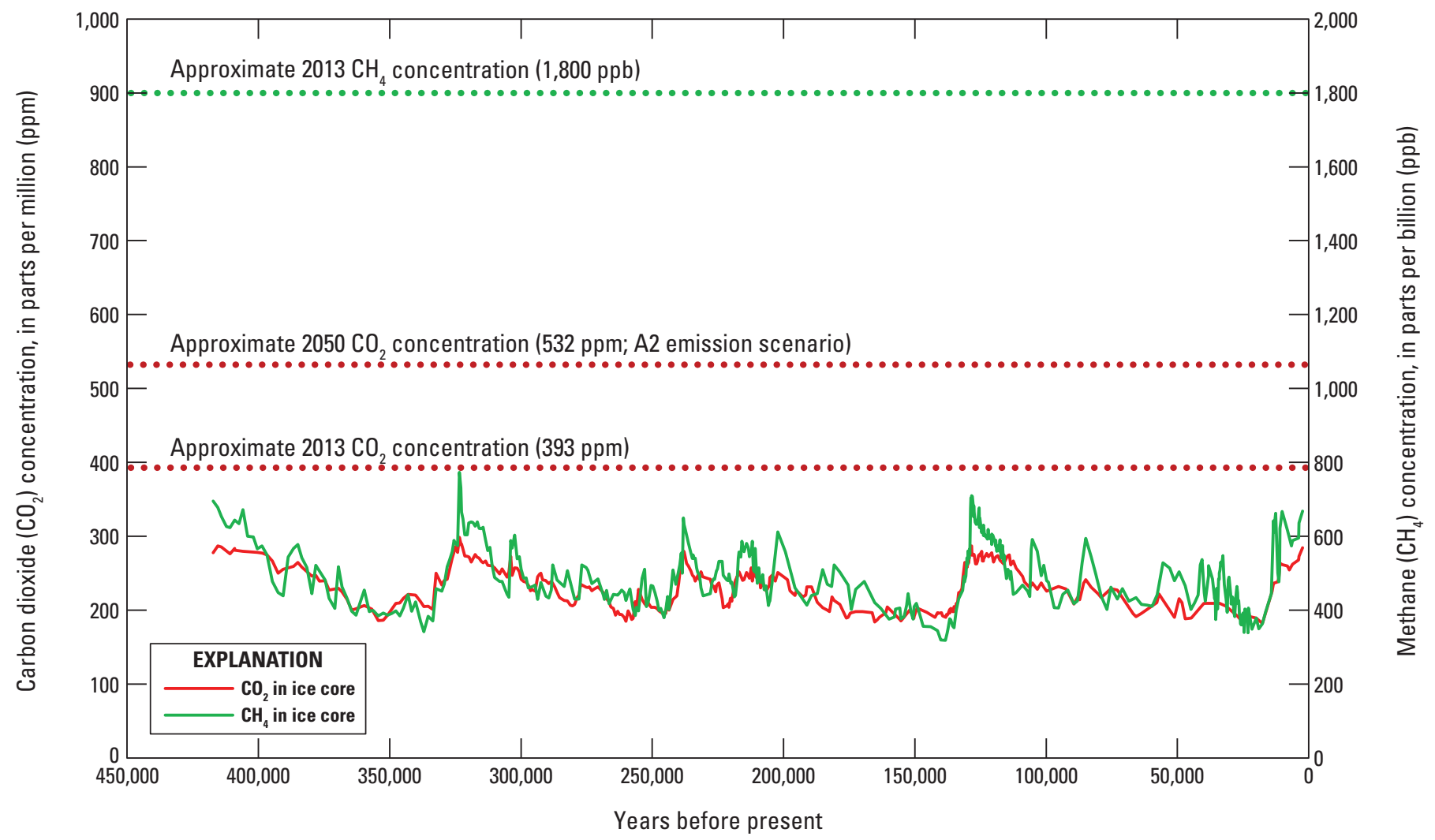

Figure 3. Concentrations of greenhouse gases on the basis of the Vostok ice core, and current (2013) and projected concentrations (Petit and others, 1999; National Climatic Data Center, 2013).

followed by relatively cool conditions of the Little Ice Age from 1400 to 1700 (Mann and others, 2009). The Medieval Climate Anomaly is the most recent analog to modern and future climate warmth, but it was unlikely to have been notably warmer than the current climate (Solomon and others, 2007). It has been proposed that the onset of the Little Ice Age was triggered by a period of explosive volcanism rather than large changes in orbital or solar forcing (Miller and others, 2012); however, the PAGES 2k Consortium (2013) propose that there is no globally synchronous warm or cold period that defines a worldwide Medieval Warm Period or Little Ice Age.

Paleoclimatic variability for central Texas has been investigated with several proxies, including floral and faunal records, speleothems, and tree rings. Most proxy studies provide insight into climate variability at millennial scales for the Pleistocene to Holocene time periods, particularly around the last glacial period. The last glacial period in central Texas was likely relatively cool [as much as $5-6{ }^{\circ} \mathrm{C}$ cooler than modern (Toomey and others, 1993)] and wet (Cooperative Holocene Mapping Project members, 1988; Toomey and others, 1993; Nordt and others, 1994; Musgrove and others, 2001). Holocene climate generally has been characterized as warming and drying throughout, accompanied by soil erosion (Cooke and others, 2003) and shifts in floral and faunal assemblages (Toomey and others, 1993; Nordt and others, 1994; Bousman, 1998). Glacial meltwater pulses to the Gulf of Mexico, the dominant moisture source to central
Texas, also likely affected regional climate, resulting in cooler climate conditions (Nordt and others, 2002). To date (2013), few climate studies for central Texas provide higher resolution (centennial or decadal) paleoclimatic proxies for the Holocene. Tree-ring studies have reconstructed drought cycles for central Texas since 1500 and indicate that extended (decadal or longer) droughts that exceeded the 1950s drought in length or intensity occurred throughout the study period (Cleaveland and others, 2011).

The sensitivity of the Great Plains to climate change is indicated by geologic evidence from the Holocene Epoch and by historical accounts such as the effects of the "Dust Bowl" of the 1930s on the landscape and on climate of the Midwest. Before the Dust Bowl, accounts from explorers indicate that dunes in the northern and central Great Plains might have been active in the 1800s with sources of sands being wide, sandy rivers that frequently were dry (Muhs and Holliday, 1995). These dunes are part of the Sand Hills (fig. 1), a sand sea that covered much of central and northern Nebraska. Sustained dune activity in the Sand Hills of central Nebraska, which indicates relatively warm conditions, has been identified for 9,600 to 6,500 years before present (YBP), and episodes of dune activity from 4,500 to 2,300 YBP and 1,000 to $700 \mathrm{YBP}$ (Medieval Climate Anomaly) might have occurred in response to frequent and severe drought (Miao and others, 2007). Similar periods of climate change are indicated by pollen and diatoms that are preserved in sediment cores from Moon Lake, 
a small, closed-basin lake in the glaciated terrane of eastern North Dakota (fig. 1). Laird and others (1996) inferred lake salinity using diatom assemblages at Moon Lake, and the results indicate a transition from an open freshwater lake to a closed saline lake between 10,000 to 7,300 YBP, as vegetation shifted from spruce forests to deciduous parkland to prairie, and a high-salinity lake associated with drier climatic conditions from 4,700 to 2,200 YBP. Studies of tree-ring records in western Nebraska have identified multiple periods of drought, averaging 12.9 years long, between 1539 and 1939 (Weakly, 1943). Periods between droughts were, on average, 20.6 years long. Much of this time period was within the relatively cool conditions of the Little Ice Age. A study of forest structure in the Black Hills noted a coincident pluvial (wet) period occurring from the late 1700 s to early 1800 s, following an intense 10-year drought around 1750 (Brown, 2006).

\section{Ecological Setting}

The Balcones Escarpment comprises one of the most biologically diverse regions in the Nation (The Nature Conservancy, 2008) with unique, relict, and endemic terrestrial, aquatic, and stygobitic (subterranean) biota (Longley, 1986; Amos and Gehlbach, 1988; Bowles and Arsuffi, 1993; U.S. Fish and Wildlife Service, 1996; Zara Environmental, 2010). This diversity is driven in part by local and regional climatic gradients (fig. 2), rugged topography, and availability of rivers and isolated springs (Brune, 1981), and reflects the junction of two major physiographic provinces - the Coastal Plain to the southeast and the Great Plains to the north (fig. 1) (Fenneman, 1931). About 200 endemic aquatic species and 9 endemic terrestrial plant species are associated with the canyons and springs of the Balcones Escarpment (supplemental table S1-1). In addition to surface-dwelling species, the Balcones Escarpment has a rich stygobitic fauna, with 42 described species (Hershler and Longley, 1986; Peck, 1998; Zara Environmental, 2010).

The Edwards aquifer surface-recharge area along the Balcones Escarpment (fig. 4) lies within 6 U.S. Environmental Protection Agency Level IV ecoregions and represents 4 of the 12 Level III ecoregions in Texas: Cross Timbers (ecoregion 29), Edwards Plateau (ecoregion 30), Southern Texas Plains (ecoregion 31), and Texas Blackland Prairies (ecoregion 32) (Griffith and others, 2004). The contributing zone to the north of the aquifer and much of the recharge zone lie within the Balcones Canyonlands (Level IV ecoregion 30c), an area of highly dissected limestone outcrops that forms the southern edge of the Edwards Plateau. The upland vegetation in this ecoregion predominately is woodland and park (Bezanson, 2000), and is dominated by plateau live oak [Quercus fusiformis (NatureServe, 2013)], Ashe juniper (Juniperus ashei), cedar elm (Ulmus crassifolia), and Texas oak (Quercus buckleyi). Canyons in this region are characterized by fast-flowing rivers and streams that support cool, moist microclimates on north-facing slopes. Vegetation in the canyons varies across local moisture gradients, from riparian forests along the stream corridors to mesic (having moderate or well-balanced supply of water) north-slope deciduous forests to drier evergreen woodland on exposed slopes (Van Auken, 1988; Griffith and others, 2004). The seeps and springs of the limestone canyons support endemic, rare, and relict plant species (Amos and Rowell, 1988; Bezanson, 2000). Westernmost remnants of eastern deciduous species occur within the Balcones Canyonlands (Blair, 1950; Correll and Johnston, 1970). These species include relicts of eastern swamp communities, such as American sycamore (Platanus occidentalis), black willow (Salix nigra), and bald cypress (Taxodium distichum), that occur along large streams (Gehlbach, 1981; Riskind and Diamond, 1988). Precipitation declines from east to west across the Balcones Escarpment (fig. 2), causing a shift to more xeric vegetation in the western parts of the ecoregion including Acacia sp., honey mesquite (Prosopis glandulosa), and cenizo (Leucophyllum frutescens) (Bezanson, 2000; Griffith and others, 2004). In these dry western regions, more mesic species associated with the plateau live oak woodland are restricted to north- and east-facing canyon slopes and flood plains.

Although most of the Balcones Escarpment lies within the Balcones Canyonlands ecoregion (ecoregion 30c), a small western part of the recharge and confined zones lies in the Texas-Tamaulipan Thorn Scrub ecoregion (ecoregion 31c) (fig. 4). This ecoregion, also called "the brush country," is characterized by subtropical climate with hot, dry summers and mild winters. Precipitation occurs erratically and predominantly in spring and fall. Dominant vegetation along the southwestern edge of the Balcones Escarpment includes guajillo (Senegalia berlandieri), cenizo (Leucophyllum frutescens), and honey mesquite (Prosopis glandulosa).

Most of the confined zone of the Edwards aquifer lies within two Level IV ecoregions - the Northern Nueces Alluvial Plains and the Northern Blackland Prairie (ecoregions 31a and 32a, respectively) (fig. 4). The deep soils of the Northern Nuesces Alluvial Plains form a distinct boundary with the Balcones Canyonlands at the southern edge of the Balcones Escarpment. The physiography of this ecoregion is formed partly by the many streams flowing from the Balcones Canyonlands across the Balcones Escarpment and also from the spring-fed streams of the confined zone. The dominant vegetation types include mesquite/live oak/bluewood (Condalia hookeri) parks to the north with mesquite/granjeno (Celtis pallida) parks and mesquite/blackbrush (Acacia rigidula) brush to the south (fig. 4) (McMahan and others, 1984; Bezanson, 2000; Griffith and others, 2004).

The northeastern part of the confined zone lies in the Northern Blackland Prairie (Level IV ecoregion 32a) (fig. 4) and includes Comal Springs and Barton Springs. This area is named after the "black waxy" shrink-swell clays that were historically dominated by tallgrass prairie species, including little bluestem (Schizachyrium scoparium), big bluestem (Andropogon gerardii), yellow indian-grass (Sorghastrum nutans), and tall dropseed (Sporobolus compositus) (Diamond and Smeins, 1993; Griffith and others, 2004). This ecoregion is under heavy cultivation and urbanization, but some existing 


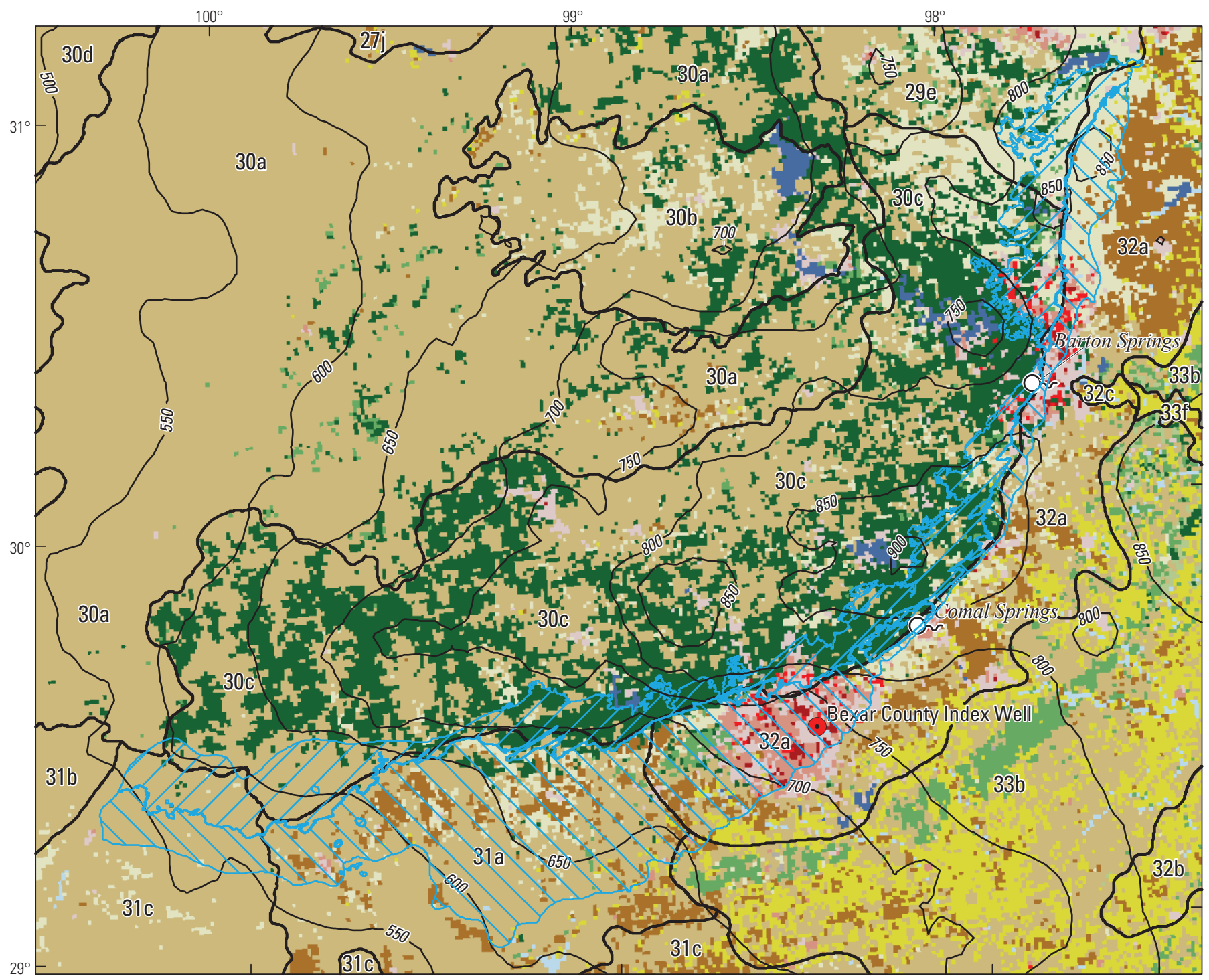

Base from U.S. Geological Survey data Transverse Mercator

North American Datum of 1983

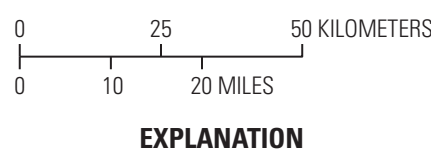

Comal Springs Or Spring or spring complex and identifie

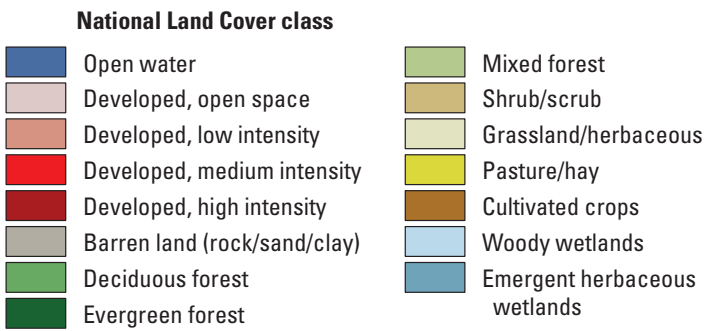

$7 \triangle$ Edwards aquifer surface-recharge area

1.V Edwards aquifer below land surface - Confined

Level IV ecoregion boundary

-550- Isohyet of annual precipitation, 1901-2000-Interval 50 millimeters

\section{Bexar County Index Well $\odot$ Well and identifier}

\section{Level IV ecoregion identifier}

27j Limestone Plains

29 e Limestone Cut Plain

30b Llano Uplift

30c Balcones Canyonlands

30d Semiarid Edwards Plateau

31a Northern Nueces Alluvial Plains 30a Edwards Plateau Woodland 31b Semiarid Edwards Bajada

31c Texas-Tamaulipan Thorn Scrub

32a Northern Blackland Prairie

32b Southern Blackland/Fayette Prairie

32c Floodplains and Low Terraces

33b Southern Post Oak Savanna

$33 f$ Floodplains and Low Terraces

Figure 4. Ecoregions and land cover of Edwards aquifer sites and the surrounding region. 
mesquite/live oak/bluewood parks occur in the northwest corner of the region and silver bluestem [Bothriochloa laguroides (NatureServe, 2013)]/Texas wintergrass (Nassella leucotricha) grasslands occur in the far northeastern end of the ecoregion. Riparian forests in this ecoregion are characterized by pecan (Carya illinoinensis), eastern cottonwood (Populus deltoides), elm (Ulmus spp.), ash (Fraxinus spp.), sugar hackberry (Celtis laevigata), Shumard's oak (Quercus shumardii), and bur oak (Quercus macrocarpa).

The Black Hills ecological setting is "a forested island in a grassland sea" and is described by Froiland (1990, p.1). The name Black Hills comes from the contrast between the dark ponderosa pine (Pinus ponderosa) dominated forest characteristic of the Black Hills and the lighter colored grasslands of the surrounding Great Plains. The Black Hills lie within the Middle Rockies Level III ecoregion (U.S. Environmental Protection Agency, 2011), reflecting the geologic and ecological connections between the Black Hills and the Rocky Mountains (fig. 1).

The three Level IV ecoregions comprised by the Black Hills are related to climate patterns and topographic setting, which are associated with the geologic setting (Bryce and others, 1996; Chapman and others, 2004) (fig. 5). The Black Hills Foothills (ecoregion 17a) includes the broad valleys of the Red Valley and the encircling hogback ridge, which separates the foothills from the surrounding plains. The climate, warmer and drier than in other parts of the Black Hills, and the more gentle topography in the Red Valley is associated with open ponderosa pine woodlands interspersed with mixed-grass prairie (Larson and Johnson, 2007). The Black Hills Plateau (ecoregion 17b) is in the mid altitudes of the Black Hills and encompasses areas underlain by the Minnelusa Formation and lower altitude parts of the Limestone Plateau and the crystalline core. The Black Hills Core Highlands (ecoregion $17 \mathrm{c}$ ) includes the highest altitude parts of the crystalline core and Limestone Plateau and are characterized by cooler temperatures and higher precipitation than other parts of the Black Hills. Although ponderosa pine forest predominates throughout the Black Hills Plateau and Black Hills Core Highlands, extremely variable topography, from broad ridges and entrenched canyons to highly dissected, tilted rock faces, produces a variety of ecological communities (Larson and Johnson, 2007; Chapman and others, 2004).

The greatest concentrations of biological diversity in the Black Hills commonly are associated with surface water. All major streams within and flowing out of the Black Hills receive flows from aquifers, of which the Madison aquifer is a primary contributor. Flow from Rhoads Fork Spring is derived from the Madison aquifer, and 91 percent of streamflow in Spearfish Creek (fig. 1) is contributed as base flow from the Madison aquifer (Driscoll and Carter, 2001); however, short-term precipitation contributes strongly to streamflow in tributaries originating in the crystalline core (Driscoll and Carter, 2001), and these reaches provide important surface water for flora and fauna. Perennial water flow provides habitat for species requiring more mesic, and sometimes cooler, conditions than are available in most of the Black Hills. In these areas, deciduous hardwood trees and shrubs such as box elder (Acer negundo), green ash (Fraxinus pennsylvanica), American elm (Ulmus americana), birch (Betula spp.), eastern cottonwood (Populus deltoides), willow (Salix spp.), dogwood (Cornus spp.), and chokecherry (Prunus virginiana) are most abundant and combine into riparian forest and shrubland communities (Marriot and Faber-Langendoen, 2000). Herbaceous wetlands characterized by sedges (Carex and Eleocharis spp.), bulrushes (Scirpus and Schoenoplectus spp.), rushes (Juncus and Luzula spp.), cattails (Typha spp.), and some grasses (Poaceae) occur in small areas around surface water as well. With time, flowing streams have carved steep canyons, whose rock faces and shaded valleys provide special habitat required by a few disjunct species such as green spleenwort (Asplenium trichomanes-ramosum). Spearfish Creek and its associated canyon are an example of this type of habitat.

The ecological communities of the Black Hills are unique combinations of flora and fauna from many parts of North America, from eastern deciduous, northern boreal, and Rocky Mountain forests to Great Plains grasslands, Great Basin sagebrush shrublands, and southwest deserts (McIntosh, 1931; Froiland, 1990). Because of this confluence of ecological regions, many species reach their geographical limitseastern, western, northern, and southern - in the Black Hills (Froiland, 1990); however, unlike in the Balcones Escarpment region, the species that compose these communities are not unique. The Black Hills host isolated populations, varieties, or subspecies of some organisms (and some taxa are understudied), but endemism at the species level is considered rare to nonexistent. In addition, the caves of the Madison Limestone generally are dry, and therefore provide little habitat for the types of unique species that inhabit caves of the Balcones Escarpment. Few cave-obligate species have been described for the Black Hills (Culver and others, 2003), which likely reflects the lack of biota rather than a lack of looking (Culver and others, 2000), because geologic exploration of the caves in the region is extensive. Obligate species occur only in a specific habitat, such as in caves (cave obligate) or groundwater (groundwater obligate).

\section{Methods and Models}

Given the complexity of karst aquifers, innovative methods were required to model and evaluate their hydrologic response to projected climate change, information critical for assessing the vulnerability of associated species to climate variability and change. Observations and models used for the assessment (fig. 6) span scales from global-scale climate forcings to local-scale responses of aquifers and vulnerability of species at selected sites. Existing records of daily air temperature and precipitation (National Climatic Data Center, 2012; Long and Mahler, 2013) for National Oceanic and Atmospheric Administration (NOAA) weather stations (fig. 1) were used to establish a time series of historical climate trends and 


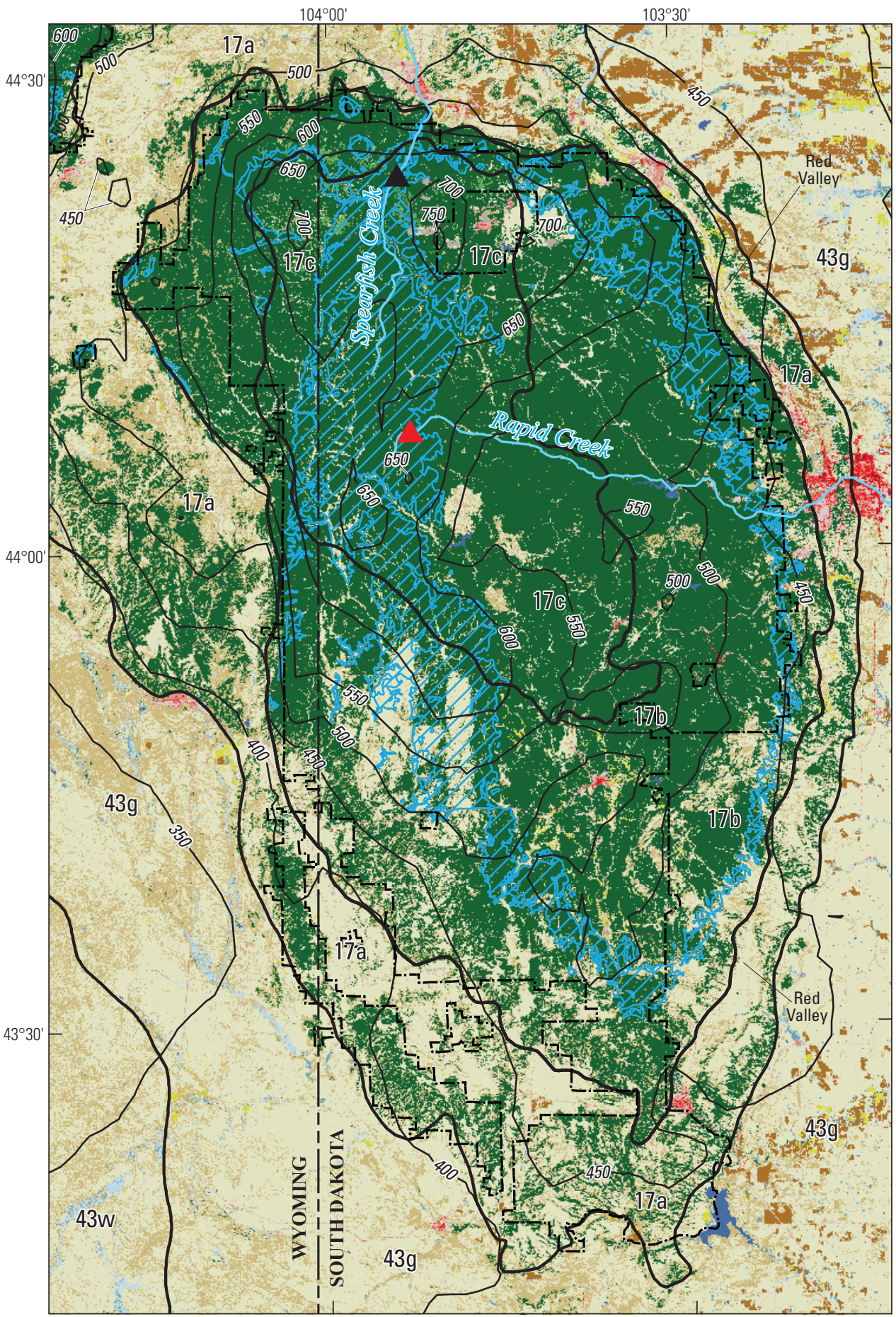

Base from U.S. Geological Survey data Transverse Mercator North American Datum of 1983

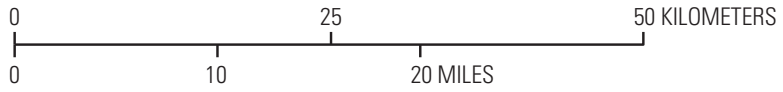

\section{EXPLANATION}

National Land Cover class

Open water

Developed, open space

Developed, low intensity

Developed, medium intensity

Developed, high intensity

Barren land (rock/sand/clay)

Deciduous forest

Evergreen forest

Mixed forest

Shrub/scrub

Grassland/herbaceous

Pasture/hay

Cultivated crops

Woody wetlands

Emergent herbaceous wetlands

7 Madison aquifer surface-recharge area

— Level IV ecoregion boundary

- - - Black Hills National Forest boundary

-450- Isohyet of annual precipitation, 1901-2000 - Interval 50 millimeters

Spearfish Creek streamgage

Rhoads Fork Spring streamgage Level IV ecoregion identifier

17a Black Hills Foothills

17b Black Hills Plateau

17c Black Hills Core Highlands

$43 \mathrm{~g}$ Semiarid Pierre Shale Plains

43w Powder River Basin

Figure 5. Ecoregions and land cover of Madison aquifer sites and the surrounding region. 


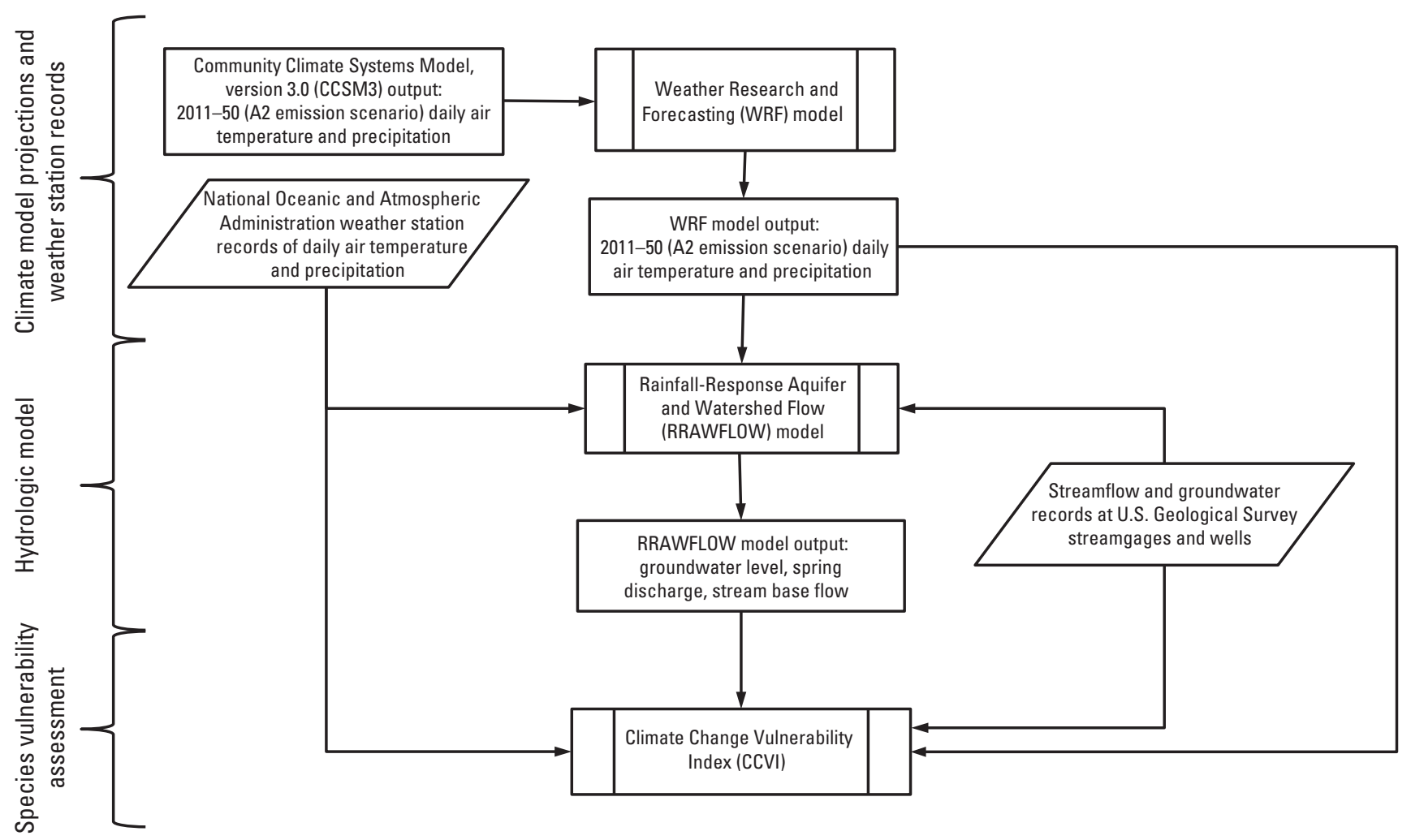

EXPLANATION

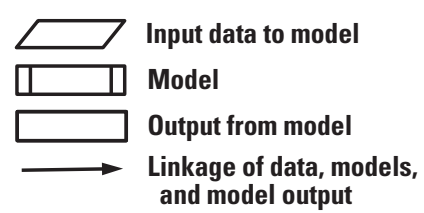

Figure 6. Linkage of model components. The final linkage is to the Climate Change Vulnerability Index for selected species.

variability from as early as 1905 through at least 2010. Output from the CCSM3 was adapted to provide initial and boundary conditions to the WRF model. The WRF model output for grid points nearest the location of weather stations was used to project air temperature and precipitation daily time series from 2011 to 2050 . Hydrologic response to climate, historical and projected, was simulated using the RRAWFLOW model, a versatile time-series model that simulates watertable level, springflow, or streamflow at a single site using records of daily precipitation and air temperature as model input (Long and Mahler, 2013). The RRAWFLOW model is available at http://sd.water.usgs.gov/projects/RRAWFLOW/ RRAWFLOW.html. The superposed responses of quick and slow flow that commonly characterize karst aquifers (for example, Pinault and others, 2001) can be simulated by the RRAWFLOW model. Vulnerability of species at Edwards and Madison aquifer sites to changes in climate was assessed using the CCVI. The CCVI requires the user to estimate scores for factors, several of which are associated with climatic and hydrologic variability. Factors also include habitat specificity, dispersal ability, barriers to migration, reliance on other species, and specific disturbance regimes (such as fire). Scores for factors are based on monthly and annual trends in climate variables, and other climate metrics such as frequency of climate events and exceedances of species tolerances to climate change (supplemental table S1-2).

\section{Weather Station Data}

Historical and projected (from the start of weather station record through 2050) daily air temperature and precipitation are required inputs for the RRAWFLOW model. The RRAWFLOW model was calibrated and validated using input data from 9 NOAA weather stations in the Black Hills and 7 NOAA weather stations in the area of the Balcones Escarpment (Long and Mahler, 2013). Each Edwards and Madison aquifer site was assigned a primary weather station for estimates of daily air temperature and precipitation at the site (table 1), such as the Lead, South Dakota, weather station for the Spearfish Creek site. Gaps in data were filled using 
Table 1. Weather stations used to synthesize climate records for the five Rainfall-Response Aquifer and Watershed Flow (RRAWFLOW) model sites and weather station period of records.

[USGS, U.S. Geological Survey; NOAA, National Oceanic and Atmospheric Administration; NAD83DD, decimal degrees in North American Datum of 1983; IDW, inverse-distance weighting interpolation method]

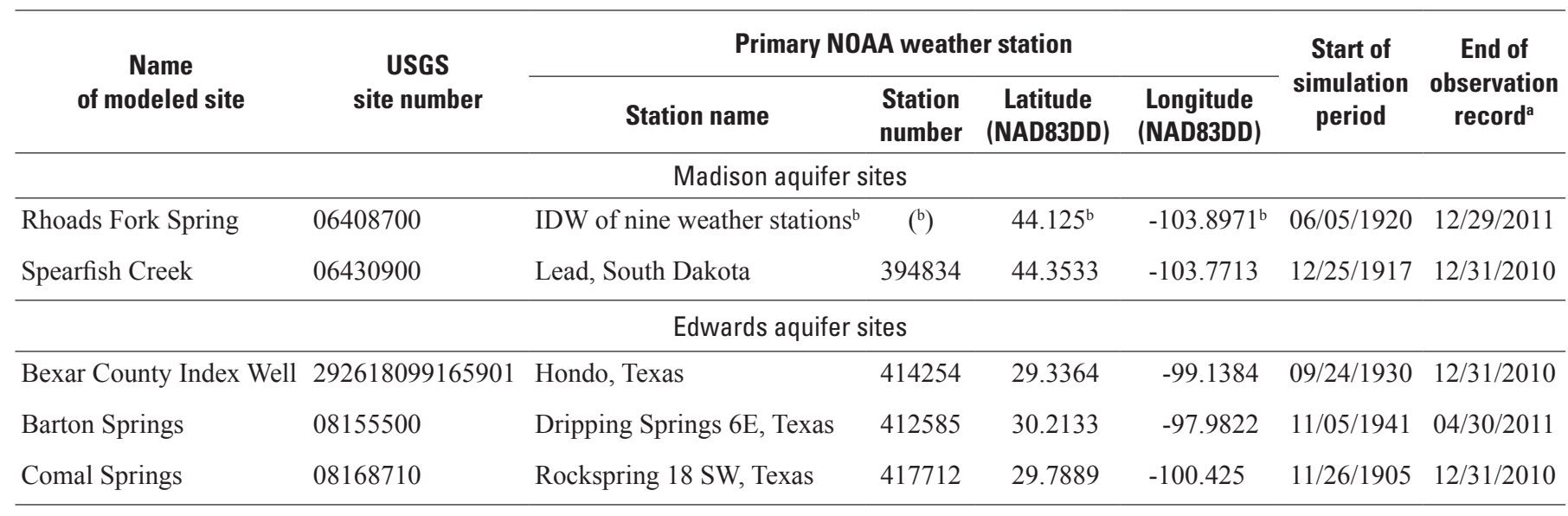

aEnd of observation record as used for RRAWFLOW calibration and validation. End of observations record used as input for RRAWFLOW simulations was $12 / 31 / 2010$ for all sites.

'Location is the approximate centroid of the contributing watershed. Name of this site referred to in text as "Rhoads Fork (interpolated)."

records from nearby weather stations, with weights assigned based on the distance to the primary weather station (Long and Mahler, 2013). A nearby weather station was not available for the Rhoads Fork Spring site, and daily air temperature and precipitation were interpolated for the center of the watershed using inverse distance weights applied to records from nine surrounding weather stations, which were located within 17 kilometers $(\mathrm{km})$ of the center of the watershed (Long and Mahler, 2013). Interpolated estimates of weather for this site will be referred to as "Rhoads Fork (interpolated)." Three NOAA weather stations were used to compute monthly and annual statistics, and metrics of climate variability for the CCVI assessments: the Boerne weather station in Texas (1906-2010), and the Custer (1943-2010) and Lead (1918-2010) weather stations in South Dakota (fig. 1; table 2). A limited set of statistics and metrics for the Rhoads Fork (interpolated) site were computed and considered in the CCVI assessment, and are reported in supplemental table S1-2. The breadth of statistics and metrics computed for other weather stations was not computed for Rhoads Fork (interpolated) because it was a completely synthetic record.

Table 2. Description and location for weather stations used to quantify climate variability.

[NOAA, National Oceanic and Atmospheric Administration; NAD83DD, decimal degrees in North American Datum of 1983]

\begin{tabular}{lccrrr}
\hline \multirow{2}{*}{$\begin{array}{c}\text { NOAA weather } \\
\text { station }\end{array}$} & \multirow{2}{*}{$\begin{array}{c}\text { Station } \\
\text { number }\end{array}$} & & \multicolumn{2}{c}{ Location (NAD83DD) } & Start of \\
\cline { 3 - 4 } & & Latitude & Longitude & record \\
\hline Boerne, Texas & 410902 & 29.7986 & -98.7353 & $1 / 1 / 1906$ \\
Custer, South Dakota & 392087 & 43.7744 & -103.6119 & $1 / 1 / 1943$ \\
Lead, South Dakota & 394834 & 44.3533 & -103.7713 & $1 / 1 / 1918$ \\
\hline
\end{tabular}

\section{Climate Models}

Two dynamical climate models, the WRF model and CCSM3, were linked (fig. 6) to project daily air temperature and precipitation through 2050 on the basis of the A2 emission scenario. Emission scenarios are described by the Special Report on Emission Scenarios (SRES) (Nakićenović and Swart, 2000) and the Intergovernmental Panel on Climate Change, Fourth Assessment Report (Solomon and others, 2007). The A2 emission scenario represents a world that emphasizes the importance of economy ("A" scenario) over the environment ("B" scenario), with more regional responses ("2" scenario) than global cooperation ("1" scenario). In contrast to the A2 emission scenario, the A1 emission scenario represents a world with more global cooperation, and is further classified by energy sources: fossil-fuel intensive (A1FI), nonfossil-fuel intensive because of changes in technology (A1T), and a balance across available energy sources (A1B). It is notable that the trend in atmospheric $\mathrm{CO}_{2}$ concentration for the A2 emission scenario matches the trend for the A1B scenario through 2050, with both emission scenarios attaining a concentration of 532 ppmv by 2050; however, trends through 2050 for other greenhouse gas emissions differ between the A2 and $\mathrm{A} 1 \mathrm{~B}$ emission scenarios, and trends in atmospheric $\mathrm{CO}_{2}$ concentrations from 2050-2100 diverge for the A2 and A1B emission scenarios. The A1FI emission scenario reaches the highest atmospheric $\mathrm{CO}_{2}$ concentration at 2050 of all SRES emission scenarios: 567 ppmv.

The A2 emission scenario was chosen for this study to align with regional climate model simulations as published by other groups. Regional climate model simulations at a $50-\mathrm{km}$ resolution based on the $\mathrm{A} 2$ emission scenario are available from the University Corporation for Atmospheric Research 
North American Regional Climate Change Assessment Program (http://www.narccap.ucar.edu). Simulations span 1971-2000 (contemporary climate) and 2041-70 (projected climate), and are driven by boundary conditions from several Atmosphere-Ocean General Circulation Models (AOGCMs) (table 3). Hostetler and others (2011) used the Regional Climate Model (RegCM) to simulate climate for much of North America at a $15-\mathrm{km}$ and $50-\mathrm{km}$ spatial resolution on the basis of the A2 emission scenario. The RegCM output spans 1968-99, 2040-69, and 2010-99, and boundary conditions are based on several AOGCMs (table 3). The A2 emission scenario also was chosen because observed trends in atmospheric $\mathrm{CO}_{2}$ emissions generally have followed the trend of the highest emission scenarios (Manning and others, 2010; Murray and Hansen, 2013). As previously described, the mean atmospheric $\mathrm{CO}_{2}$ concentration surpassed 400 ppmv in 2013
(National Oceanic and Atmospheric Administration, 2013), and the CCSM3 and WRF model simulations based on the A2 emission scenario assume 400 ppmv for 2013.

\section{Community Climate System Model}

The CCSM3 is an AOGCM of global climate, and is described by Collins and others (2004). Gridded output from CCSM3 is available at $\sim 1.4$-arc-degree grid spacing and a 6-hour time step for 1870-2100, and model output can be downloaded from the Earth System Grid Federation (http:// www.earthsystemgrid.org). Although model output is reported for calendar years (such as 1870), AOGCMs such as the CCSM3 are not constrained to precisely match historical weather patterns from year to year. This is what distinguishes

Table 3. Dynamical mesoscale models for North American climate and associated Atmosphere-Ocean General Circulation Model (AOGCM).

[NARCCAP, North American Climate Change Assessment Program; km, kilometer]

\begin{tabular}{|c|c|c|c|c|}
\hline Source & Mesoscale model & AOGCM boundary conditions & Time span & Resolution \\
\hline NARCCAP & $\begin{array}{l}\text { Canadian Climate Centre Regional Climate } \\
\text { Model (CRCM) }\end{array}$ & $\begin{array}{l}\text { Community Climate System Model, version } 3 \\
\text { (CCSM3) }\end{array}$ & $\begin{array}{l}1971-2000 \\
2041-70\end{array}$ & $50 \mathrm{~km}$ \\
\hline NARCCAP & $\begin{array}{l}\text { Hadley Centre Regional Climate Model } \\
\text { (HRM3) }\end{array}$ & $\begin{array}{l}\text { Geophysical Fluid Dynamics Laboratory } \\
\text { Climate Model, version 2.1 (GFDL CM2) }\end{array}$ & $\begin{array}{l}1971-2000 \\
2041-70\end{array}$ & $50 \mathrm{~km}$ \\
\hline NARCCAP & Mesoscale Model, version 5 (MM5) & $\begin{array}{l}\text { Community Climate System Model, version } 3 \\
\text { (CCSM3) }\end{array}$ & $\begin{array}{l}1971-2000 \\
2041-70\end{array}$ & $50 \mathrm{~km}$ \\
\hline NARCCAP & Mesoscale Model, version 5 (MM5) & $\begin{array}{l}\text { Met Office Hadley Centre Climate Model } \\
\text { (HadCM3) }\end{array}$ & $\begin{array}{l}1971-2000 \\
2041-70\end{array}$ & $50 \mathrm{~km}$ \\
\hline NARCCAP & $\begin{array}{l}\text { Advanced Research Weather Research and } \\
\text { Forecasting (WRF, ARW) model }\end{array}$ & $\begin{array}{l}\text { Community Climate System Model, version } 3 \\
\text { (CCSM3) }\end{array}$ & $\begin{array}{l}1971-2000 \\
2041-70\end{array}$ & $50 \mathrm{~km}$ \\
\hline NARCCAP & $\begin{array}{l}\text { Advanced Research Weather Research and } \\
\text { Forecasting (WRF, ARW) model }\end{array}$ & $\begin{array}{l}\text { Canadian Climate Centre GCM, version 3.1/T63 } \\
\text { (CGCM3) }\end{array}$ & $\begin{array}{l}1971-2000 \\
2041-70\end{array}$ & $50 \mathrm{~km}$ \\
\hline $\begin{array}{l}\text { Hostetler and } \\
\text { others, } 2011\end{array}$ & Regional Climate Model, version 3 (RegCM3) & $\begin{array}{l}\text { Max Planck Institute, European Center for } \\
\text { Medium range Weather Forecasting GCM, } \\
\text { Hamburg, version } 5 \text { (MPI ECHAM5) }\end{array}$ & $\begin{array}{l}1968-99 \\
2040-69 \\
2010-2100\end{array}$ & $50 \mathrm{~km}, 15 \mathrm{~km}$ \\
\hline $\begin{array}{l}\text { Hostetler and } \\
\text { others, } 2011\end{array}$ & Regional Climate Model, version 3 (RegCM3) & $\begin{array}{l}\text { Geophysical Fluid Dynamics Laboratory } \\
\text { Climate Model, version 2.1, (GFDL CM2) }\end{array}$ & $\begin{array}{l}1968-99 \\
2040-69 \\
2010-2100\end{array}$ & $50 \mathrm{~km}, 15 \mathrm{~km}$ \\
\hline
\end{tabular}


a climate model from a weather forecast model. As such, climate modelers use the terms "pre-industrial climate" and "contemporary climate" rather than "historical climate." A year in the late $1800 \mathrm{~s}$, such as 1850 or 1870 , is selected to represent pre-industrial climate conditions, and is simulated for many annual cycles until AOGCM output stabilizes. Stabilization or "spin-up" reflects the model's dynamical adjustment of important hydrologic and energy budget components, such as soil moisture and soil temperature, from the conditions set for the initial time step. The CCSM3 pre-industrial climate simulation selected for this study computed the climate in 1870 for 440 annual cycles (experiment b30.020e). The CCSM3 simulation of contemporary climate is a continuation from the pre-industrial climate simulation (annual cycle 440), and is based on observed $\mathrm{CO}_{2}$ concentrations from 1870 to 1999 (experiment b30.030e). This simulation commonly is referred to as the 20th Century Climate in Coupled Models (20C3M). Climate models do not use the term "future climate," but use the term "projected climate" to recognize that greenhouse gas emissions in the future are uncertain. The CCSM3 simulation of projected climate is a continuation from the 20C3M simulation, based on an emission scenario from 2000 to 2100 (experiment b30.042e for the A2 emission scenario). The experiments selected for $20 \mathrm{C} 3 \mathrm{M}$ and projected climate (b30.030e and b30.042e, respectively) were the only CCSM3 simulations of the A2 emission scenario for which a subdaily (6-hour) time step for model output was available. A subdaily time step, on the order of 6 hours or less, is required for the WRF model boundary conditions.

Simulations based on several AOGCM simulations, or multiple emission scenarios, were outside the scope of this study. Therefore, AOGCM simulations were screened on the basis of the skill in simulating contemporary climate of the Great Plains during 1901-2012. In addition to the CCSM3, the Canadian Centre for Climate Modeling and Analysis General Circulation Model, version 3.1/T63 (CGCM3) (Environment Canada, 2013) and the Geophysical Fluid Dynamics Laboratory Climate Model, version 2.1 (GFDL CM2) (Geophysical Fluid Dynamics Laboratory, 2013) were considered. Output from these AOGCMs was compared to monthly and annual surface air temperature and precipitation from the PRISM (described in the "Historical Climate" section) (figs. 7 and 8). The PRISM output of monthly means of daily minimum and maximum air temperature were averaged to estimate monthly means of daily mean air temperature.

Plots of model output from AOGCMs (CCSM3, GFDL $\mathrm{CM}$, and CGCM3) and from the PRISM for grid points within the area of the Great Plains (fig. 7) for the time period 1901-2012 indicate that the CCSM3 has the better skill in estimating annual mean air temperature than the GFDL CM2 and CGCM3. The GFDL CM2 and CGCM3 have a cold bias of $\sim 3{ }^{\circ} \mathrm{C}$ relative to the PRISM, whereas the CCSM3 has a cold bias of $\sim 0.3{ }^{\circ} \mathrm{C}$ relative to the PRISM. All models have a wet bias in mean annual precipitation relative to the PRISM: 288, 53, and $139 \mathrm{~mm}$ for the GFDL CM2, CGCM3, and CCSM3, respectively. Note that projected annual precipitation for all models becomes more consistent after approximately 2030.

Relative to the PRISM output, climate based on the GFDL CM2 is cooler and wetter. Relative to the PRISM output, the CGCM3 simulated cooler climate but has the best skill for simulating precipitation of the three AOGCMs. The CCSM3 and GFDL CM2 overestimate precipitation for June and July (fig. 8), which are months that are dominated by convective precipitation systems. The CCSM3 has the closest match of mean monthly air temperature with PRISM output of the AOGCMs. Given these comparisons of time series (fig. 7) and monthly means (fig. 8) of AOGCMs and the PRISM output for the area of the Great Plains, the CCSM3 was chosen as boundary conditions for the WRF model because it had the best skill for simulating air temperature yet retained a moderate skill, relative to other AOGCMs, simulating precipitation.

\section{Weather Research and Forecasting Model}

The Advanced Research version of the Weather Research and Forecasting (WRF) model, version 3.4.1 (described by Skamarock and others, 2008), is a regional climate model and was adapted to simulate climate of North America at a 36-km grid spacing (fig. 9) based on initial and boundary conditions from the CCSM3. Two WRF model simulations were computed: 1981-2010 (contemporary climate) and 2001-50 (projected climate). Climate variables were specified to be output at 3-hour intervals (computational time steps are much shorter), and were then integrated to daily and monthly time steps. Computationally similar to the atmospheric component of AOGCMs, such as in the CCSM3, the WRF model simulates several atmospheric variables, including temperature, pressure, moisture, and winds at multiple levels in the atmosphere, and hydrologic variables, including precipitation, evapotranspiration, soil moisture, and runoff at the land surface.

In the "Community Climate System Model" section, comparisons were made between AOGCM solutions of annual precipitation and air temperature for the Great Plains. At the scale of the Great Plains, the WRF model simulations of annual precipitation and air temperature for the Great Plains generally follow those of the CCSM3 (fig. 10). This is expected given that for large areas, the mean for the area computed using the CCSM3 and WRF model simulations would be expected to converge. Additional descriptions of applications of the WRF model to the study areas of this report are given in the "Climate Trends and Statistics" section and other sections of this report.

The WRF model is a modular program that includes the WRF model Preprocessing System (WPS), which is used to prepare input data to the WRF model, as described in the Advanced Research WRF Modeling Users Guide (Wang and others, 2012). The WPS includes a program "metgrid" that inputs gridded observations of atmospheric temperature, 

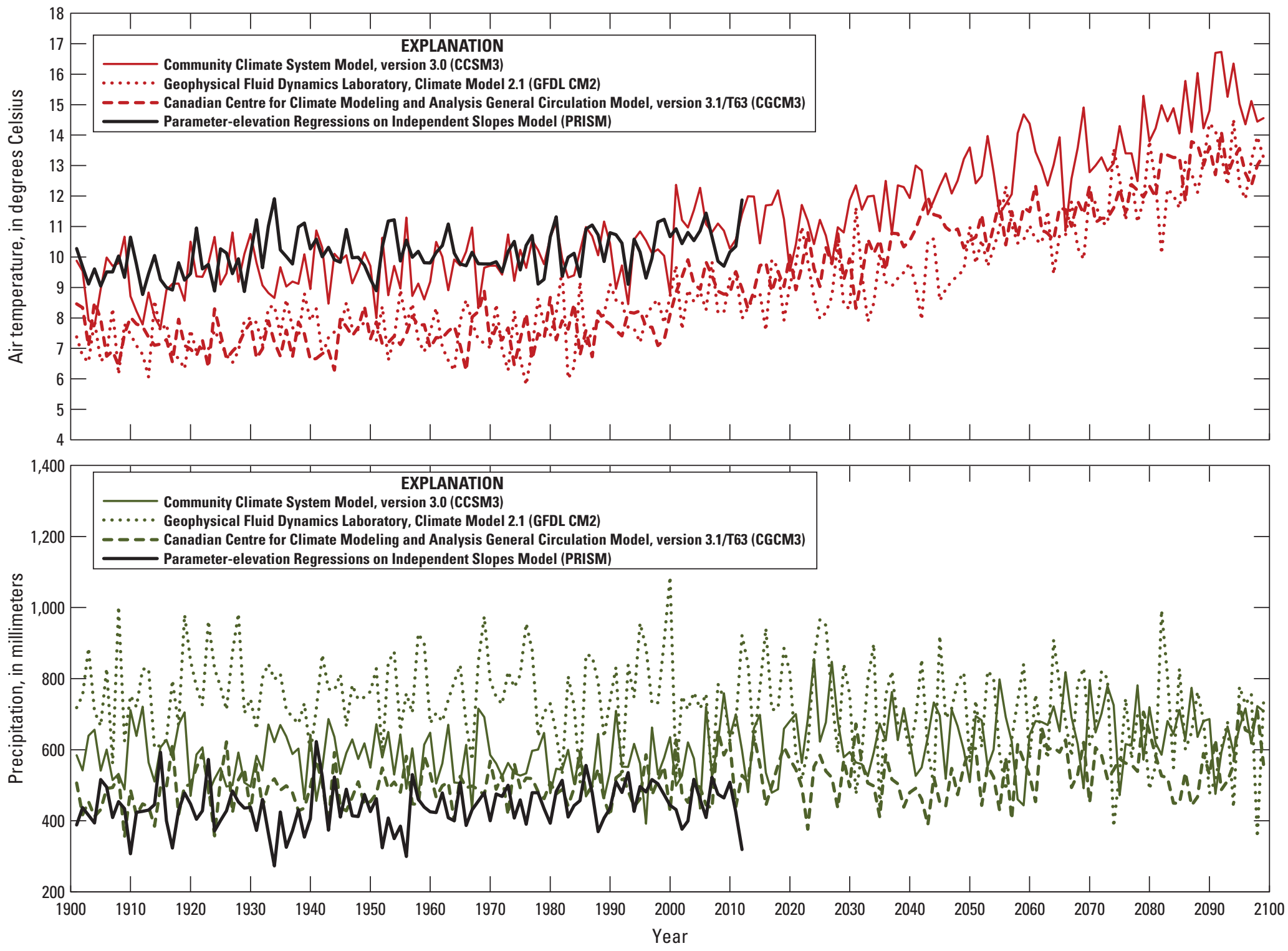

Figure 7. Time series of annual mean surface air temperature and total precipitation during 1901-2099 for the area of the Great Plains for three general circulation models, and during 1901-2012 for the Parameter-elevation Regressions on Independent Slopes Model (PRISM). 

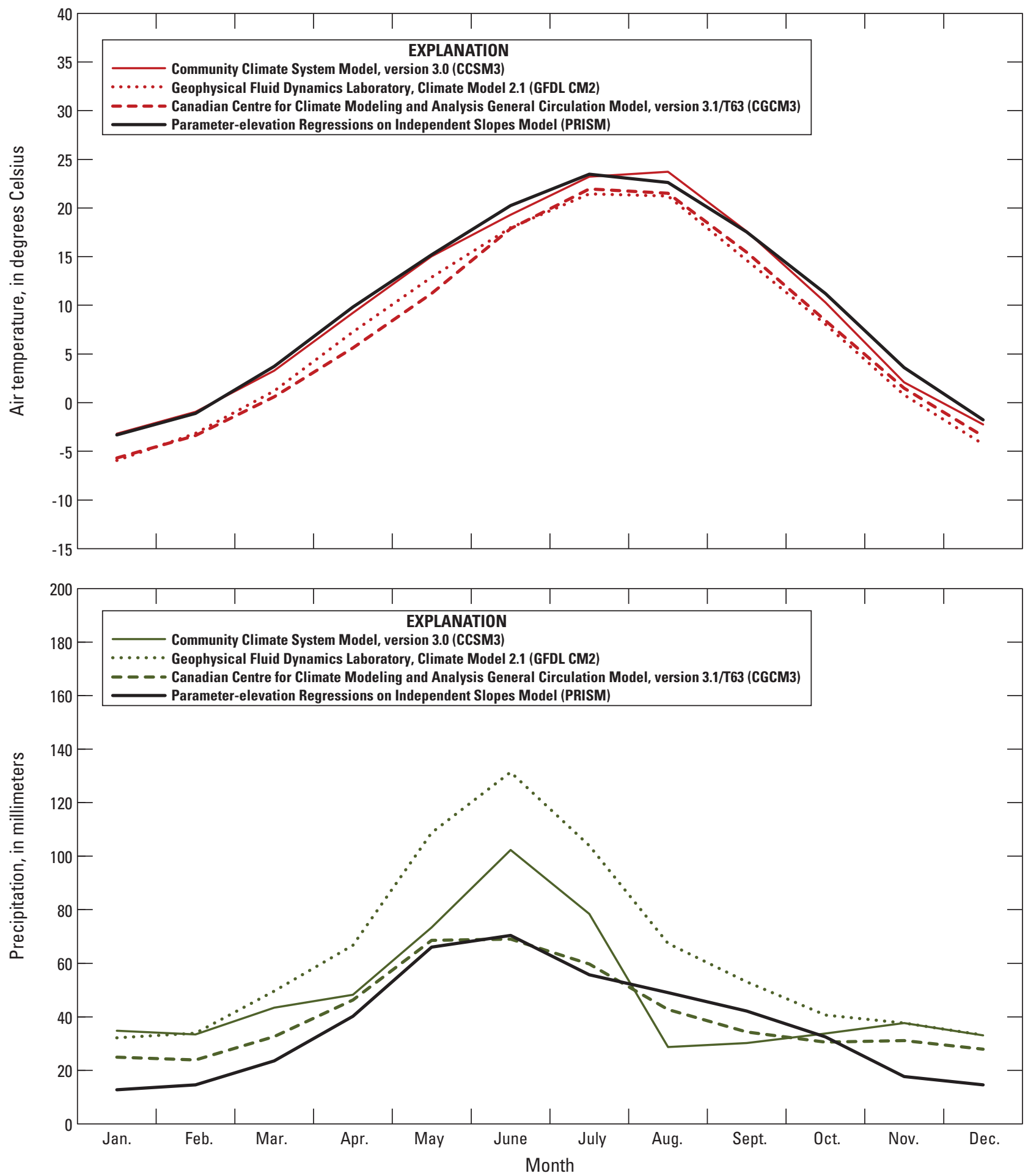

Figure 8. Mean monthly surface air temperature and total precipitation during 1901-2012 for the area of the Great Plains for three general circulation models and for the Parameter-elevation Regressions on Independent Slopes Model (PRISM). Note that the line marking PRISM air temperature in places overlies and obscures the line for the Community Climate System Model, version 3 (CCSM3). 


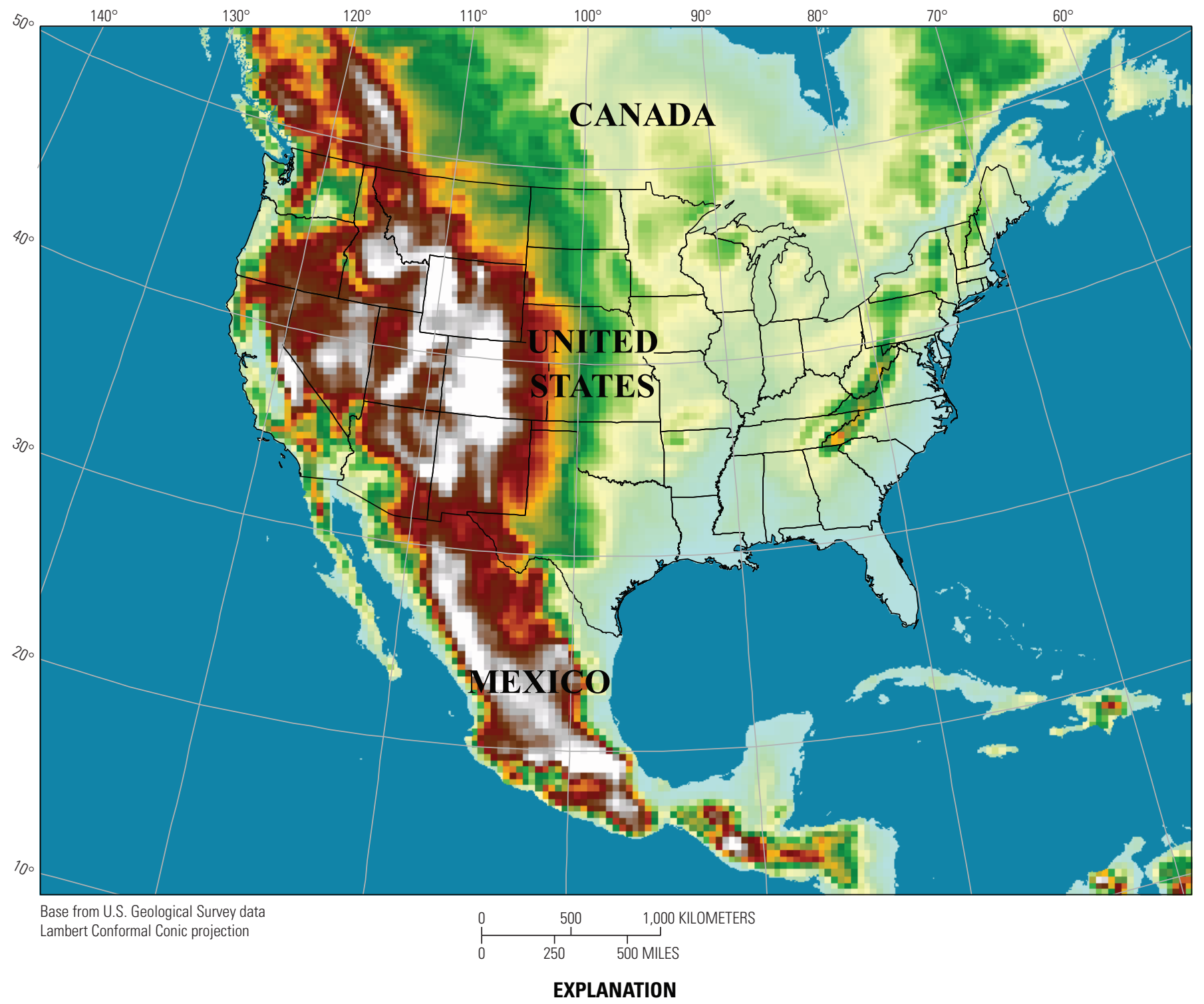

Land-surface altitude - In meters above North American Vertical Datum of 1988

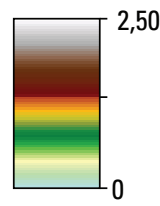

Figure 9. The Weather Research and Forecasting (WRF) model domain extent showing land-surface altitudes at the 36-kilometer resolution. 

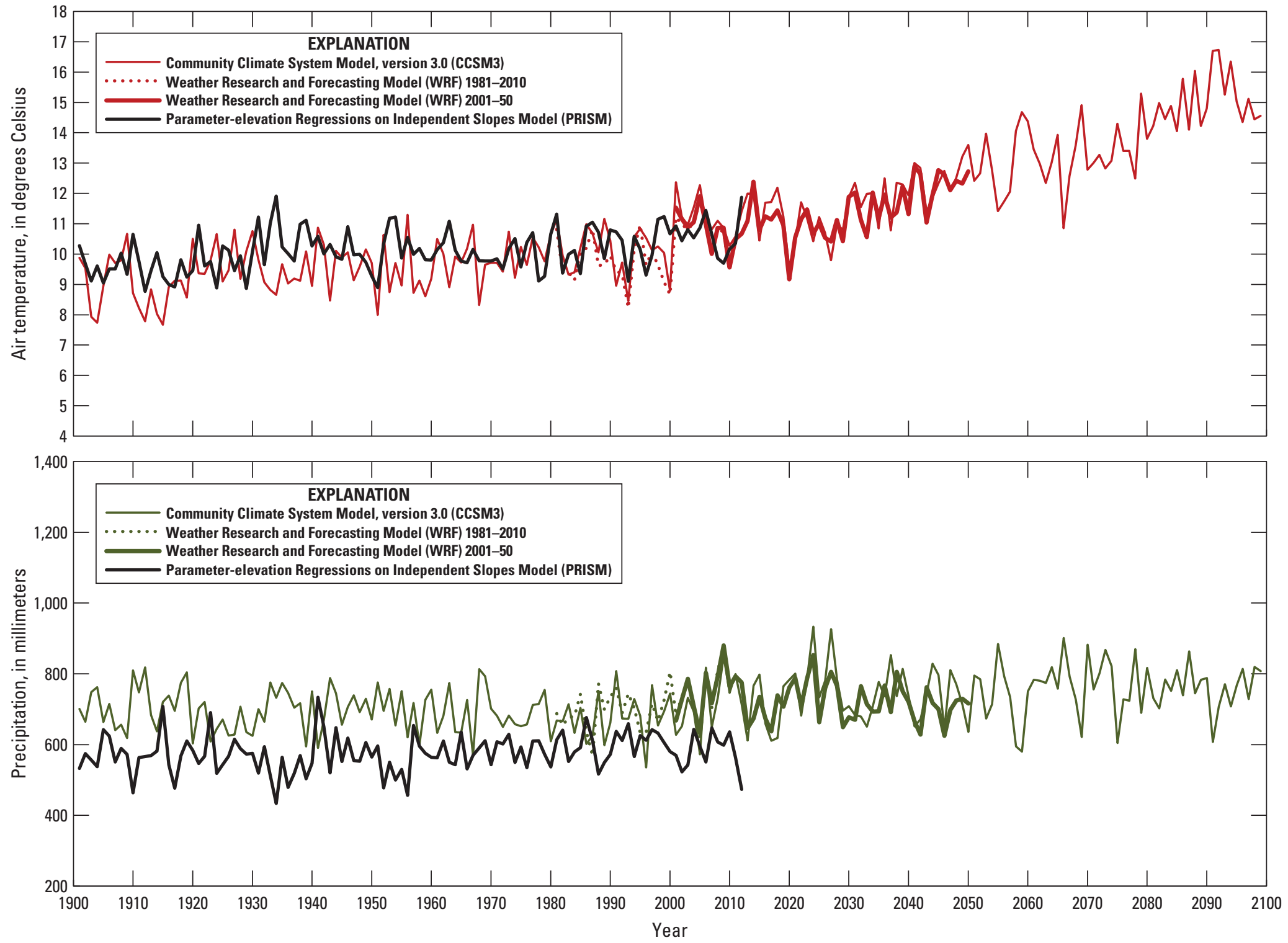

Figure 10. Time series of annual mean surface air temperature and total precipitation for the area of the Great Plains from the Community Climate System Model, version 3 (CCSM3), two simulations from the Weather Research and Forecasting (WRF) model (1981-2010 and 2001-50), and the Parameterelevation Regressions on Independent Slopes Model (PRISM). 
winds, and moisture at several heights in the atmosphere and interpolates to specified pressure levels. The metgrid program was adapted to accept input from the CCSM3, and is based on code supplied by the Mesoscale and Microscale Meteorology Division of the National Center for Atmospheric Research and originally developed by Pacific Northwest Laboratories. The adapted program, named "ccsmgrid," also reformats soil moisture, soil temperature, sea-surface temperature, and lake temperature from the CCSM3 output. Lake temperatures were computed in ccsmgrid from the daily mean of the CCSM3 surface air temperature over the lake. Other boundary conditions, such as land-surface altitude, land use, soil moisture capacity, dominant vegetation in a grid cell, monthly changes in the vegetation (greening), and albedo, were based on standard datasets used for the WRF model simulations (Wang and others, 2012) and do not change from year to year; however, variables associated with vegetation and albedo exhibit an annual cycle.

Several subgrid scale processes are represented within the WRF model, and programs that represent these processes are referred to as "physics schemes." The physics schemes selected for the simulation presented in this report are listed in table 4. Several of the selected physics schemes previously have been applied to weather and climate modeling in the northern Great Plains (such as Capehart and others, 2011). The radiation scheme selected is the Community Atmosphere Model (CAM), and adjusts for projected $\mathrm{CO}_{2}$ concentrations on the basis of the A2 emission scenario [other scenarios are not currently (2013) available in this radiation scheme]. The CCSM3 also uses the CAM radiation scheme.
Selected physics schemes, model setup, and input datasets are specified in the WRF model namelist files, which are described by Wang and others (2012). The term "namelist" is derived from Fortran programming to specify groups of input and output variables. Templates of namelist files used for the WRF model runs described in this report are included as text files "namelist.wps" and "namelist.input" in the "Supplement 3" section. The text file "namelist.README" in the "Supplement 3" section provides a glossary of terms listed in the namelist.wps and namelist.input files.

Assessment of species vulnerability required estimates of local climate from 2010-50, represented in this study by the WRF model projections of daily precipitation, and mean, maximum, and minimum daily air temperature (2-m height) for grid cells that include the locations of Edwards and Madison aquifer sites and weather stations (tables 1 and 2). Bias of the WRF model simulations was computed as the difference in mean annual air temperature and mean monthly precipitation between the WRF model output and weather station observations during 1981-2010. Separate bias adjustments were computed for mean, maximum, and minimum air temperature. Model bias in mean monthly precipitation was computed using both days with and without precipitation to compute mean monthly precipitation for 1981-2010; however, bias adjustment was made only to days for which the model predicted a precipitation event. If bias adjustment resulted in precipitation less than $0.025 \mathrm{~mm}$ [the resolution of standard tipping bucket rain gages (Ahrens, 2007)], precipitation was set to zero. These steps were repeated iteratively until bias in daily mean precipitation for the given month was less than $0.0001 \mathrm{~mm}$ per day.

Table 4. General description of physics schemes used in the Weather Research and Forecasting (WRF) model.

[Specific physics schemes are described in more detail in Wang and others (2012); mm, millimeters]

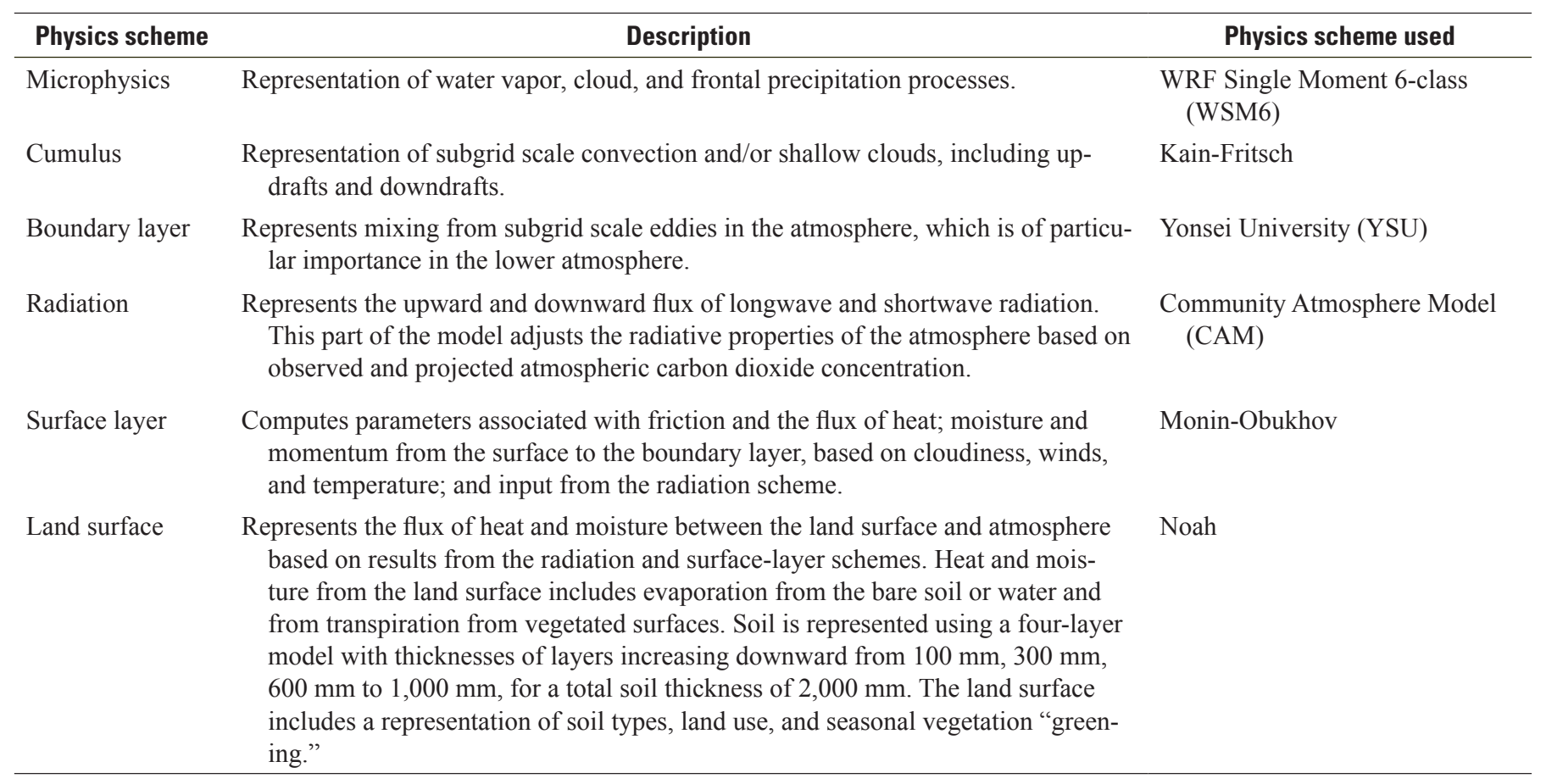


Once bias adjustments were completed for air temperature and precipitation, a continuous time series was constructed using weather station records through 2010 and projected through 2050 using bias-adjusted WRF model output. Bias adjustments are listed in supplemental table S3-1.

\section{Hydrologic Model}

The RRAWFLOW model is a time-series model that simulates springflow or water-table level (in a well) using observed or projected climate data (air temperature and precipitation) as input. The model simulates two processes in series: the process of precipitation becoming recharge, and the transition of recharge into a hydrologic response. The method, described in detail in Long and Mahler (2013), is summarized in this section. Groundwater recharge was simulated using a method similar to effective-precipitation methods (Jakeman and Hornberger, 1993). First, a daily soil-moisture index was estimated; the index is a function of antecedent conditions, which in turn are related to daily air temperature and daily total precipitation. Second, daily recharge was computed as the product of the daily soilmoisture index and daily precipitation. Daily precipitation was either rain or snow; the occurrence of snow precipitation and melting for projected periods was determined on the basis of air temperature threshold values. Third, the transition of recharge to a hydrologic response was simulated using convolution. Convolution can be used to simulate the translation of a system input into a system output that is dispersed in time according to a characteristic waveform, or impulse-response function (IRF). The IRF describes the system output that results from an instantaneous unit input. For surface water, the IRF is called the unit hydrograph. The length of the IRF quantifies the system "memory," or the time that the response to the impulse effectively persists. Exponential curves, lognormal curves, or a combination of the two were used to approximate IRFs. Flow in karst can consist of flow through large conduits (quick flow) and through fractures (slow flow); in some cases, a single IRF can adequately represent the quick-flow and slow-flow components, but in other cases, a secondary IRF is useful to represent all or part of the slow-flow component (Long, 2009). The primary and secondary IRFs were superposed to form a compound IRF.

Because of horizontal and vertical heterogeneity in karst, which can cause fluctuating water-table levels to saturate or desaturate different parts of the aquifer having different conduit networks, the IRF might vary with time. To address this, IRFs were determined for wet periods and dry periods, assuming time invariance within these periods. The wet and dry periods were defined as years in which the annual precipitation was greater than or less than the long-term mean, respectively. Therefore, as many as four IRFs were used to simulate the system output: primary IRFs ( $I R F_{w l}$ and $\left.I R F_{d l}\right)$ and secondary IRFs $\left(I R F_{w 2}\right.$ and $\left.I R F_{d 2}\right)$, where the subscripts, $w$ and $d$, refer to wet and dry periods, respectively.
The model for each site was validated by (1) optimizing model parameters for part of the existing record of system output (calibration period), (2) executing the calibrated model for the remaining observation period using the optimized parameters (validation period), and (3) comparing the simulated and observed outputs for the validation period. Model performance for the calibration and validation periods was evaluated on the basis of the Nash-Sutcliffe coefficient of efficiency, $E_{N-S}$ (Nash and Sutcliffe, 1970; Legates and McCabe, 1999), which is a measure of the similarity between simulated and observed time-series records, hereafter referred to as model "fit." An $E_{N-S}$ value of zero indicates that the observed mean is as good a predictor as the simulation (poor fit); an $E_{N-S}$ value of unity is a perfect fit. A target $E_{N-S}$ for the validation period was set at 0.70 , calculated on a daily time step.

For each Edwards and Madison aquifer site, a model was calibrated and validated by using recorded (observed) mean daily air temperature and precipitation as model input, and by comparing simulated output (water-table level and springflow) to the observed time series from the USGS National Water Information System (http://waterdata.usgs.gov/nwis). The validated model was then applied to historical and projected mean daily air temperature and precipitation from the nearest weather station from the start of record through 2050 to simulate a continuous record of hydrologic response.

\section{Species Assessment}

A large number and wide variety of species are associated with the springs, streams, and groundwater of the Edwards and Madison aquifers. Some of these species are of special conservation concern because of their local or global rarity or factors other than (or in addition to) climate change that threaten their persistence. A list of karst-related species of conservation concern was compiled for the Balcones Escarpment and Black Hills regions. For inclusion on this list, a species was required to meet two criteria.

1. The species is designated as at least one of the following:

a. threatened or endangered under Federal or State law;

b. a sensitive species, species of local concern, or management indicator species by Federal or State land-management agencies;

c. having a Natural Heritage rank (NatureServe, 2013) of 1, 2, or 3 (critically imperiled, imperiled, or vulnerable, respectively) at the global or State level (Texas for the Balcones Escarpment, and Wyoming and South Dakota for the Black Hills); or

d. is newly discovered and therefore not yet assigned a Natural Heritage rank. 
2. The species is strongly tied to karst hydrology in the region, in that at least one part of its life cycle relies heavily or exclusively on karst hydrology, or an endemic karst obligate species is dependent on it for habitat or reproduction (two species in the Balcones Escarpment), or its occurrences within the target region are wholly or largely limited to springs or streams fed by the aquifer, moist caves, the wetland or riparian areas created by these features, or the aquifer itself.

Of the species considered for inclusion, 231 species from the Balcones Escarpment and 25 species from the Black Hills met these criteria (supplemental table S1-1). From these, 14 species from the Balcones Escarpment and 8 species from the Black Hills were selected for climate change vulnerability assessment because together the species span the range of broad taxonomic groups (such as mammal, bird, and plant), the species are tied to the hydrological features simulated in this report, and ecological information is sufficiently available on the species to meet the minimum information criteria of the vulnerability assessment tool. Two plant species that did not meet these criteria, Ehretia anacua and Cabomba caroliniana, were also selected for climate change vulnerability assessment because of their importance as habitat for endangered species in the Balcones Escarpment region, resulting in a total of 16 species from the Balcones Escarpment region.

A species' vulnerability to climate change is determined by (1) the character, magnitude, and rate of changes of climatic parameters to which it is exposed ("exposure"); (2) physiological, biological, and ecological factors that determine how the species is likely to be affected by the climate changes ("sensitivity"); and (3) the ability of the species to cope with climate change effects ("adaptive capacity") (Glick and others, 2011). The CCVI incorporates these three components (Young and others, 2012). The CCVI is programmed in a Microsoft Excel workbook, and is described by Young and others (2012). Briefly, the user assigns one or more categorical scores to 2 measures of direct exposure, 4 measures of indirect exposure, and 16 measures of sensitivity and adaptive capacity (table 5). Assigning more than one score indicates uncertainty. Scores categorize whether the effect of the factor decreases, somewhat decreases, does not affect, somewhat increases, increases, or greatly increases the species' vulnerability to climate change; the user can also assign the effect of the factor as neutral or as unknown. The direct exposure scores are used to weight scores assigned to all other factors, a weighted sum of the factors is calculated, and the weighted sum is categorized into a 5-point vulnerability index: not vulnerable/increase likely, not vulnerable/presumed stable, moderately vulnerable, highly vulnerable, or extremely vulnerable. The not vulnerable/increase likely score reflects that evidence supports an increase in the abundance or range of the species. The not vulnerable/presumed stable score reflects that evidence does not support a change in abundance or range of the species. This index is adjusted according to scores the user assigns to additional factors based on documented or simulated response of the species to climate change (table 5). If too many factors are scored as "unknown," the index is "insufficient evidence." A "Monte Carlo" approach (Young and others, 2012) was used, in which 1,000 simulations were computed, each randomly selecting a single vulnerability score for each factor in which more than one score was assigned. The distribution of results was used to calculate the statistical confidence in the vulnerability score as low, moderate, high, or very high. Supplemental table S1-2 provides detailed descriptions of how scores for each factor and for each species were assigned.

Application of CCVI for the Balcones Escarpment and Black Hills regions varies slightly from the standard protocol described by Young and others (2011). First, the standard protocol uses climate change values provided by Climate Wizard (available at http://www.climatewizard.org), in which air temperature, precipitation, and aridity are compared between the historical period (1951-2000) and the future period (2040-69), with the climate of the future period being a 16-model ensemble mean of the A1B emission scenario. As stated previously, the term "projected climate" rather than "future climate" is used in this report to recognize that greenhouse gas emissions in the future are uncertain. Application of CCVI described in this report uses observed, simulated, and projected climate and hydrological values for specific RRAWFLOW model sites (table 1) and weather stations (table 2). The "historical" and "projected" periods are redefined as the weather station's first full year of observation through 1975, and 2041-50, respectively. Climate trends from 2011 to 2050 also are considered.

Second, assessments of trends in climatic and hydrologic anomalies and indices provided information for assigning scores to two factors, C2ai and C2bi (table 5), which address the air temperature and precipitation variation, respectively, that the species has been exposed to during the 33-70 years prior to 1975 (table 5). In the standard protocol, the score for factor C2ai is derived as the difference between the highest mean monthly maximum air temperature and lowest mean monthly minimum air temperature for the area occupied by the species within the assessed region, and factor C2bi is derived as the maximum difference in mean annual precipitation values over the species' range within the region. Because of the very small range (less than 100 square kilometers) of some of the species assessed in this report, these differences are not appropriate. Instead, air temperature variation for the species is computed as the difference between mean July (warmest month) maximum air temperature and mean January (coldest month) minimum air temperature for the historical period. Precipitation variation for the species is computed as four times the standard deviation of annual precipitation during the historical period.

Third, assessment for trends in climatic and hydrologic anomalies and indices provided information for assigning scores to three factors, C2aii, C2bii, and C2c (table 5), which address vulnerability and dependence on a disturbance regime. In the standard protocol, factors C2aii and C2bii, which respectively address the physiological thermal and 
Table 5. Factors scored in the Climate Change Vulnerability Index (CCVI) and climate and hydrologic input used for scoring.

[Differences between historical and projected are calculated as means of historical (start of record through 1975) and projected (2041-50) periods, whereas trends are evaluated for historical (start of record through 1975), projected (2011-50), and complete (start of record through 2050) time periods; ${ }^{\circ} \mathrm{C}$, degrees Celsius]

\begin{tabular}{|c|c|c|}
\hline Factor & Description & Climate and hydrologic input \\
\hline \multicolumn{3}{|r|}{ Direct exposure } \\
\hline A1 & Air temperature change & Difference between projected and historical mean annual air temperature $\left({ }^{\circ} \mathrm{C}\right)$. \\
\hline \multicolumn{3}{|r|}{ Indirect exposure } \\
\hline B1 & Species' exposure to sea level rise & None applicable for assessment areas. \\
\hline $\mathrm{B} 2 \mathrm{~b}$ & $\begin{array}{l}\text { Species' distribution relative to anthropogenic } \\
\text { barriers to range shift }\end{array}$ & None. \\
\hline B3 & $\begin{array}{l}\text { Impact of land use change due to human re- } \\
\text { sponse to climate change }\end{array}$ & None. \\
\hline
\end{tabular}

\begin{tabular}{lcc}
\hline & Species-specific sensitivity or adaptive capacity factors \\
\hline C1 Species' dispersal and movements & None.
\end{tabular}

C2ai Species' historical thermal niche

C2aii Species' physiological thermal niche

C2bi Species' historical hydrological niche

C2bii Species' physiological hydrological niche

C2c Species' dependence on a disturbance regime likely to be impacted by climate change

C2d Species' dependence on ice, ice-edge, or snowcover habitat

C3 Species' restriction to uncommon geological features or derivatives

C4a Species' dependence on other species to generate None. habitat and vulnerability of those species to climate change

$\mathrm{C} 4 \mathrm{~b}$

Species' dietary versatility and vulnerability of prey species to climate change (animals only)

C4c Species' pollinator versatility (plants only)

None.

C4d Species' dependence on other species for None. propagule dispersal

C4e Species' dependence on an interspecific
interaction not covered by C4a through C4d

C5a Species' measured genetic variation None.

None.

None.

None.

None.
Difference between mean July maximum air temperature and mean January minimum air temperature for historical period.

Differences between historical and projected minimum and maximum air temperatures on annual and monthly basis. Trends in annual and monthly minimum and maximum air temperatures over historical, projected, and complete periods. Differences in minimum and maximum air temperature exceedance values between historical and projected periods. Difference between historical and projected periods in number of days maximum air temperature exceeds $36^{\circ} \mathrm{C}$.

Four times the standard deviation of annual precipitation over the historical period.

Differences between historical and projected annual and monthly precipitation. Trends in annual and monthly precipitation for historical, projected, and complete periods. Differences between historical and projected flood intensity and frequency, as estimated by changes in flow exceedance values, and size of peaks. Differences between historical and projected annual and monthly streamflow or springflow.

Input used for C2aii and C2bii. 
Table 5. Factors scored in the Climate Change Vulnerability Index (CCVI) and climate and hydrologic input used for scoring.Continued

[Differences between historical and projected are calculated as means of historical (start of record through 1975) and projected (2041-50) periods, whereas trends are evaluated for historical (start of record through 1975), projected (2011-50), and complete (start of record through 2050) time periods; ${ }^{\circ} \mathrm{C}$, degrees Celsius]

\begin{tabular}{lll}
\hline Factor & \multicolumn{1}{c}{ Description } & \multicolumn{1}{c}{ Climate and hydrologic input } \\
\hline C5b & $\begin{array}{c}\text { Occurrence of population bottleneck within the } \\
\text { last } 500 \text { years }\end{array}$ & None. \\
C6 & $\begin{array}{l}\text { Phenological response to changing seasonal air } \\
\text { or water temperature or precipitation } \\
\text { dynamics }\end{array}$ & None. \\
& \multicolumn{1}{c}{ Documented or simulated response to climate change } \\
\hline D1 & $\begin{array}{c}\text { Documented response of species to climate } \\
\text { change }\end{array}$ & None. \\
D2 & $\begin{array}{l}\text { Modeled future change in species' range or } \\
\text { population size due to climate change }\end{array}$ & None. \\
D3 & $\begin{array}{l}\text { Overlap of modeled future range with observed } \\
\text { modern range }\end{array}$ & None. \\
D4 & $\begin{array}{l}\text { Occurrence of protected areas in modeled future } \\
\text { distribution }\end{array}$ & None. \\
\hline
\end{tabular}

hydrological niches of the species, are based on the percentage of the species' occurrences or range that is restricted to a specific thermal or hydrological condition (table 5). Vulnerability scores for these factors in this application were assigned on the basis of detailed analyses of climatological and hydrological factors that affect the species. For example, levels of dissolved oxygen are positively correlated with springflow and negatively correlated with water temperature in Barton Springs (Mahler and Bourgeais, 2013). Dissolved oxygen sustained below 3.4 milligrams per liter for more than a month will lead to mortality of the Barton springs salamander, Eurycea sosorum (Woods and others, 2010). Adult abundance and reproduction of this salamander, which is endemic to Barton Springs, decline substantially during low discharge (Gillespie, 2011). The RRAWFLOW simulation of springflow was used in conjunction with correlations of springflow and dissolved oxygen to determine this species' vulnerability scores for factors C2aii and C2bii. In another example, air temperatures above $36^{\circ} \mathrm{C}$ can kill the American dipper (Cinclus mexicanus) if the bird cannot cool itself in water (Anderson, 2002). This is a species of concern in the Black Hills region, but not the Balcones Escarpment region. Therefore, the number of days per year with maximum air temperatures exceeding $36{ }^{\circ} \mathrm{C}$ was compared between historical and projected periods for the appropriate weather station in the Black Hills area (Lead). Other detailed climate and hydrological information used to score these factors and factor C2c (species' dependence on a disturbance regime) include anomalies and trends in air temperature, precipitation, or springflow for each month, allowing assessment of climate change effects on various stages of the species' life cycle, and differences between historical and projected flood or low flow frequencies (table 5).

Finally, the standard CCVI reduces the effect of climate exposure by one-third for obligate cave and groundwater species under the assumption that their habitat is buffered from local climate changes; however, karst aquifers are expected to respond rapidly to climate change (Loáiciga and others, 1996, 2000; Ma and others, 2004; Long and Mahler, 2013) and thus quickly affect the associated obligate cave and groundwater species. Therefore, the obligate groundwater species (stygobites) from the Balcones Escarpment were not designated as buffered from local climate changes, and the reduction of exposure by one-third was not applied to the CCVI scores.

\section{Historical and Projected Climate and Hydrologic Response}

Historical and projected climate and hydrologic response are described to characterize climate at Edwards and Madison aquifer sites, as input to the RRAWFLOW model, and as climate and hydrologic statistics required for CCVI to estimate species vulnerability. Climate variables for all weather stations used as input to the RRAWFLOW model included daily records of total precipitation $(P)$ and mean air temperature $\left(T_{\text {mean }}\right)$. Daily records of maximum air temperature $\left(T_{\max }\right)$ and minimum air temperature $\left(T_{\min }\right)$ for the Boerne, Custer, and Lead weather stations also were used for other analyses. Daily records were used to compute monthly and annual means or totals. A mean or total for a single year is referred to as 
"annual mean" and "annual total," respectively. For example, the mean of all daily maximum air-temperature records $\left(T_{\max }\right)$ for a single year is referred to as "annual mean $T_{\max }$." Similar terminology is used for means and totals for a single month: "monthly mean" and "monthly total." An average of annual means or annual totals over several years will be referred to as "mean annual." Similarly, an average of monthly means or monthly totals over several years will be referred to as "mean monthly." For example, a mean of several years of annual total precipitation $(P)$ will be referred to as "mean annual $P$." Similarly, the mean of several years of annual mean $T_{\max }$ would be referred to as "mean annual $T_{\max }$."

Projected climate variables for 2011-50 were simulated by the WRF model, and $P, T_{\text {mean }}, T_{\max }, T_{\text {min }}$ for these years are implicitly "simulated $P$," "simulated $T_{\text {mean }}$," "simulated $T_{\max }$," and "simulated $T_{\min }$." Historical and projected springflow and water-table level for all years are simulated by the RRAWFLOW model and are implicitly "simulated springflow" and "simulated water-table level."

\section{Climate Trends and Statistics}

Climate trends were analyzed at Boerne, Custer, and Lead weather stations (fig. 1; table 2). The Boerne and Lead weather stations were selected because they had the longest weather records in their respective regions. Because the Lead weather station is located in the northern Black Hills, the Custer weather station was added to characterize climate for the central Black Hills. Records used begin January 1 of 1906, 1943, and 1918 for the Boerne, Custer, and Lead weather stations, respectively, and these dates are referred to as "start of record" (SOR). Records preceding these years were available but were not used because records did not span a full calendar year. Climate projections for January 1, 2011, to December 31, 2050, were estimated using bias-corrected WRF model output.

To provide consistency in trend analysis among weather stations, trends were considered starting in the year where continuous records are available for all three stations: 19432050. Trends also were considered for two subset periods: 1943-2010 (historical) and 2011-50 (projected). Mean annual $P, T_{\text {mean }}, T_{\max }$, and $T_{\min }$ were computed for 1943-2050, 1943-2010, and 2011-50 (table 6). On the basis of weather station records from 1943-2010, mean annual $T_{\text {mean }}, T_{\text {max }}$, and $T_{\text {min }}$ at the Boerne weather station is $\sim 11$ to $14^{\circ} \mathrm{C}$ warmer than at the Custer and Lead weather stations, and mean annual $P$ at the Boerne weather station is $\sim 400$ and $\sim 160 \mathrm{~mm}$ greater than at the Custer and Lead weather stations, respectively. Mean annual $T_{\text {mean }}, T_{\max }$, and $T_{\min }$ for the Custer weather station are within 1 to $3{ }^{\circ} \mathrm{C}$ of respective means for the Lead weather station, but mean annual $P$ for 1943-2010 at the Custer weather station is $\sim 250 \mathrm{~mm}$ less than that at Lead, reflecting the variability in precipitation in the Black Hills.

The Kendall-tau nonparametric test (Kendall, 1938) was used to test for statistical significance in trends in time series of annual total $P$, and annual mean $T_{\text {mean }}, T_{\max }$, and $T_{\text {min }}$ for the Boerne, Custer, and Lead weather stations (fig. 11).
Table 6. Mean annual precipitation and air temperature (daily mean, maximum, and minimum) for years 1943-2050, 1943-2010, and $2011-50$ for selected weather stations.

[NOAA, National Oceanic and Atmospheric Administration]

\begin{tabular}{|c|c|c|c|}
\hline NOAA weather station & 1943-2050 & 1943-2010 & 2011-50 \\
\hline \multicolumn{4}{|c|}{ Mean annual precipitation $(P)$, in millimeters } \\
\hline Boerne, Texas & 922 & 892 & 974 \\
\hline Custer, South Dakota & 504 & 484 & 539 \\
\hline Lead, South Dakota & 758 & 730 & 807 \\
\hline \multicolumn{4}{|c|}{$\begin{array}{l}\text { Mean annual of daily mean air temperature }\left(T_{\text {mean }}\right) \text {, } \\
\text { in degrees Celsius }\end{array}$} \\
\hline Boerne, Texas & 19.1 & 18.7 & 19.7 \\
\hline Custer, South Dakota & 6.8 & 6.0 & 8.2 \\
\hline Lead, South Dakota & 7.6 & 7.0 & 8.5 \\
\hline \multicolumn{4}{|c|}{$\begin{array}{l}\text { Mean annual of daily maximum air temperature }\left(T_{m a x}\right), \\
\text { in degrees Celsius }\end{array}$} \\
\hline Boerne, Texas & 25.9 & 25.5 & 26.5 \\
\hline Custer, South Dakota & 13.9 & 13.4 & 14.7 \\
\hline Lead, South Dakota & 13.3 & 12.8 & 14.2 \\
\hline \multicolumn{4}{|c|}{$\begin{array}{l}\text { Mean annual of daily minimum air temperature }\left(T_{\min }\right), \\
\text { in degrees Celsius }\end{array}$} \\
\hline Boerne, Texas & 12.2 & 11.9 & 12.9 \\
\hline Custer, South Dakota & -0.6 & -1.7 & 1.3 \\
\hline Lead, South Dakota & 1.6 & 1.0 & 2.6 \\
\hline
\end{tabular}

Significance was set at the 0.05 probability [probability value ( $p$-value) less than or equal to $(\leq) 0.05$ ] of a Type I error (rejecting null hypothesis when true) for the null hypothesis: no trend $(\operatorname{tau}=0)$.

For the time series over 1943-2010, the Boerne weather station had a significant upward trend in annual total $P$, but did not have significant trends in annual mean $T_{\text {mean }}, T_{\max }$, and $T_{\min }$ (table 7). Upward trends in annual total $P$ might reflect effects of the droughts of the 1950s in south-central Texas. For the time series over 1943-2010, the Custer and Lead weather stations did not have significant trends in annual total $P$. In contrast to the Lead weather station, the Custer weather station had significant upward trends in annual mean $T_{\text {mean }}, T_{\text {max }}$, and $T_{\text {min }}$

For the WRF-model-output period (2011-50), upward trends in time series of annual mean $T_{\text {mean }}, T_{\max }$, and $T_{\min }$ were significant (table 7) at all stations. There was a significant downward trend in time series of annual total $P$ at the Boerne weather station and no significant trend in time series of annual total $P$ for the Lead and Custer weather stations.

For 1943-2050, which spans both observational records and the WRF model output, all stations had significant upward trends in time series of annual mean $T_{\text {mean }}, T_{\max }$, and $T_{\text {min }}$ (fig. 11; table 7). No trend is indicated for the time series of annual $P$ for 1943-2050 at the Boerne weather station, reflecting the offsetting of the upward trend for 1943-2050 

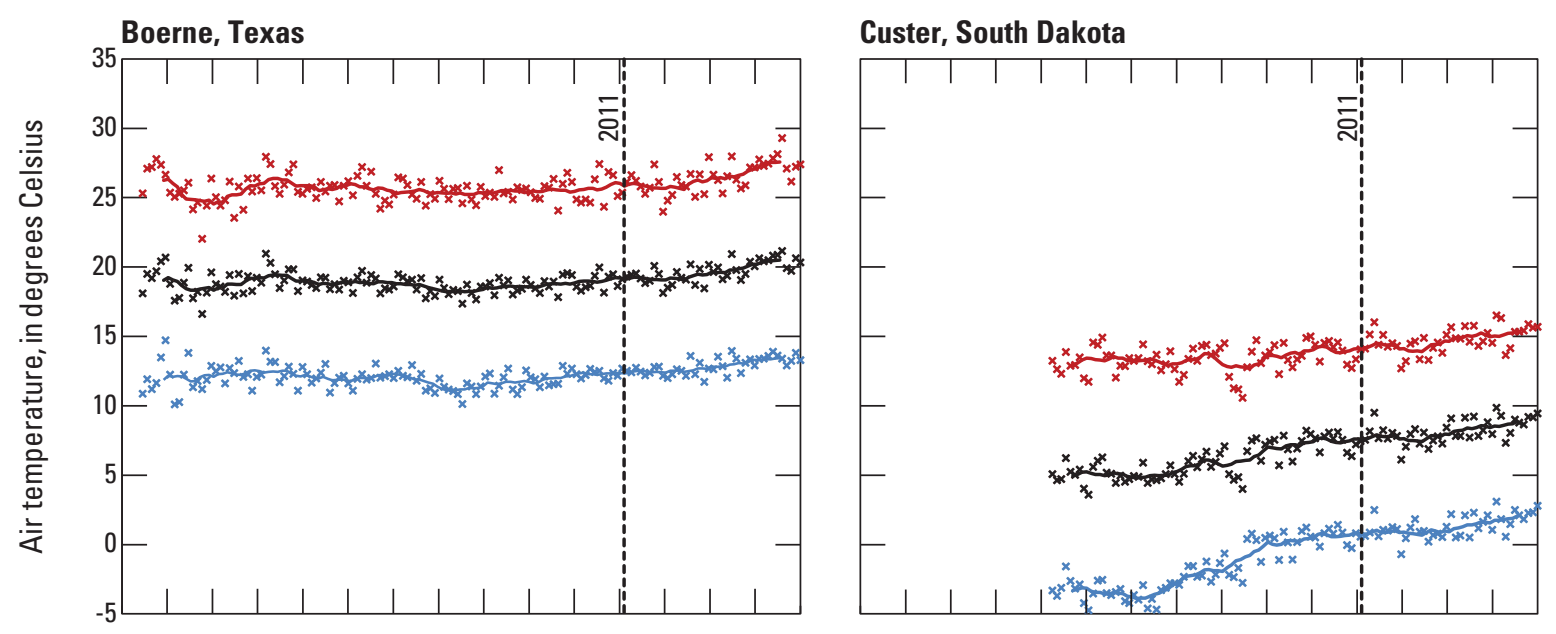

\section{Lead, South Dakota}
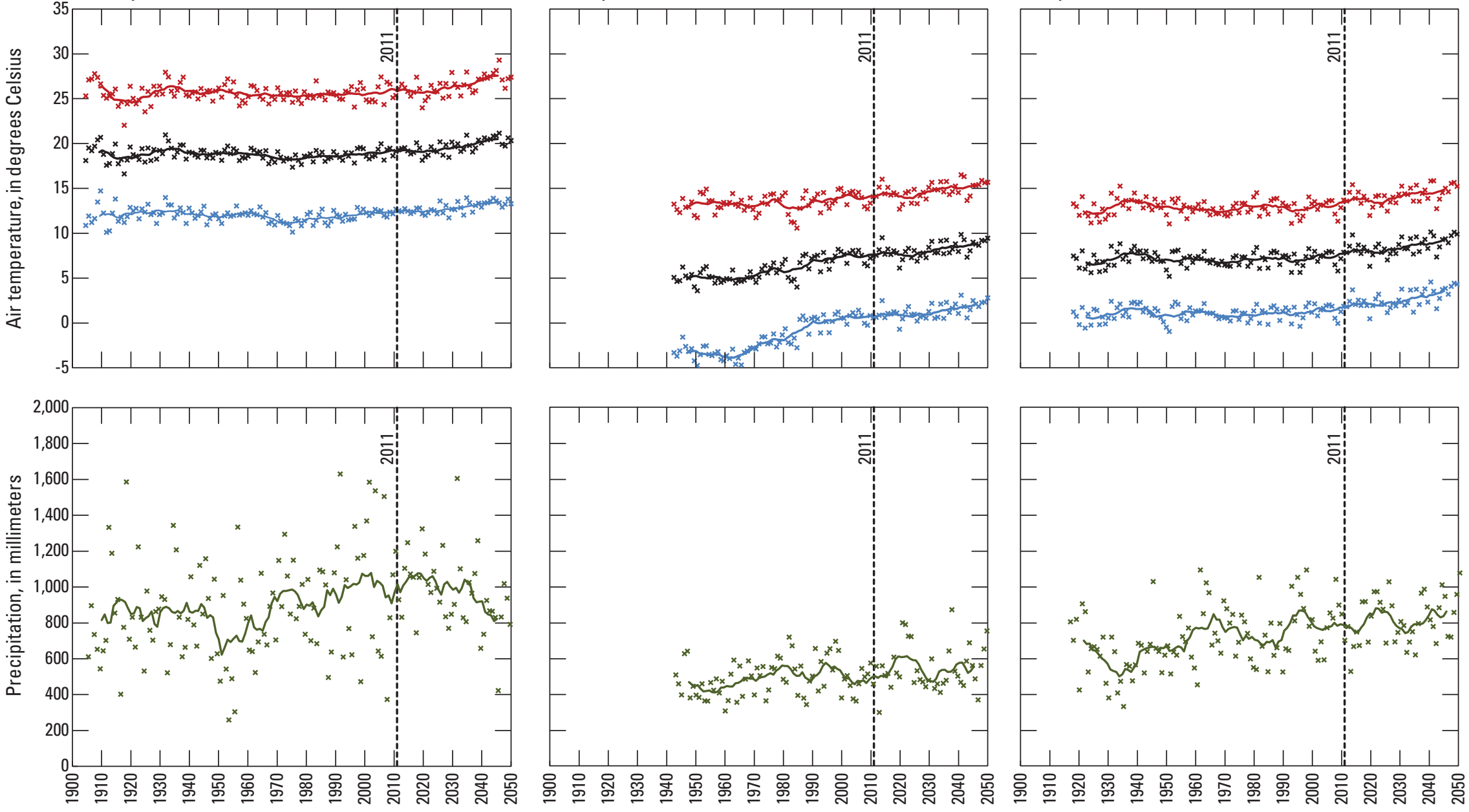

Yea
నิ

을

Figure 11. Annual total precipitation, annual mean daily air temperatures (mean, maximum, minimum), and 10-year moving means of annual values of weather station records (1943-2010) and adjusted output from the Weather Research and Forecasting Model (2011-50) for selected weather stations. 
Table 7. Results of Kendall-tau nonparametric test of significance of trends for records and climate projections for selected weather stations.

[NOAA, National Oceanic and Atmospheric Administration; Tau, measure of trend, positive values indicate upward trend, negative values indicate downward trend; $p$-value, probability of rejecting the null hypotheses (tau equals zero) when true; values in bold are statistically significant ( $p$-value less than or equal to 0.05$)$ ]

\begin{tabular}{|c|c|c|c|c|c|c|}
\hline \multirow{2}{*}{ NOAA weather station } & \multicolumn{2}{|c|}{ 1943-2050 } & \multicolumn{2}{|c|}{ 1943-2010 } & \multicolumn{2}{|c|}{$2011-50$} \\
\hline & Tau & $p$-value & Tau & $p$-value & Tau & $p$-value \\
\hline \multicolumn{7}{|c|}{ Annual total precipitation $(P)$} \\
\hline Boerne, Texas & 0.114 & 0.081 & 0.179 & 0.031 & -0.303 & 0.006 \\
\hline Custer, South Dakota & 0.183 & 0.005 & 0.158 & 0.057 & 0.059 & 0.602 \\
\hline Lead, South Dakota & 0.233 & 0.000 & 0.131 & 0.114 & 0.185 & 0.096 \\
\hline \multicolumn{7}{|c|}{ Annual mean of daily mean air temperature $\left(T_{\text {mean }}\right)$} \\
\hline Boerne, Texas & 0.398 & 0.000 & 0.007 & 0.928 & 0.457 & 0.000 \\
\hline Custer, South Dakota & 0.649 & 0.000 & 0.508 & 0.000 & 0.361 & 0.001 \\
\hline Lead, South Dakota & 0.438 & 0.000 & 0.033 & 0.687 & 0.346 & 0.002 \\
\hline \multicolumn{7}{|c|}{ Annual mean of daily maximum air temperature $\left(T_{\max }\right)$} \\
\hline Boerne, Texas & 0.287 & 0.000 & -0.033 & 0.695 & 0.403 & 0.000 \\
\hline Custer, South Dakota & 0.440 & 0.000 & 0.169 & 0.042 & 0.330 & 0.003 \\
\hline Lead, South Dakota & 0.394 & 0.000 & 0.001 & 0.987 & 0.314 & 0.004 \\
\hline \multicolumn{7}{|c|}{ Annual mean of daily minimum air temperature $\left(T_{\min }\right)$} \\
\hline Boerne, Texas & 0.446 & 0.000 & 0.069 & 0.409 & 0.414 & 0.000 \\
\hline Custer, South Dakota & 0.704 & 0.000 & 0.641 & 0.000 & 0.365 & 0.001 \\
\hline Lead, South Dakota & 0.470 & 0.000 & 0.080 & 0.335 & 0.393 & 0.000 \\
\hline
\end{tabular}

and the downward trend for 2011-50. Significant upward trends were indicated in time series of annual total $P$ for 1943-2050 at the Custer and Lead weather stations. While trends for 1943-2010 and 2011-50 were upward, they were not significant. However, trends for 1943-2010 at the Custer weather station would have been significant at the 0.06 probability.

The distribution of monthly precipitation and air temperature during a year is distinct for different climate settings of the Balcones Escarpment and the Black Hills regions. For example, mean monthly $P$ for 1943-2010 at the Boerne weather station had a bimodal distribution with peaks in May and September (fig. 12), whereas mean monthly $P$ for 1943-2010 at the Custer and Lead weather stations had a unimodal to weakly bimodal distribution, respectively. Mean monthly $P$ for $2011-50$ at the Boerne weather station has a more complex, but overall bimodal distribution, with peaks in May-June and October. Mean monthly $P$ in October for 2011-50 was $46 \mathrm{~mm}$ greater than for 1943-2010 (table 8). The distribution of mean monthly $P$ for the Custer weather station for 2011-50 is similar to that for 1943-2011 with increases in late summer and early autumn $P$ (August-October) (table 8). The weakly bimodal distribution of mean monthly $P$ for the Lead weather station becomes more strongly bimodal for 2011-50 with a 32-mm increase in mean October $P$ relative to that for 1943-2010.
The distribution of mean monthly $T_{\max }$ and $T_{\min }$ for the Boerne, Custer, and Lead weather stations indicates a general upward shift in air temperature from 1943-2010 to 2011-50 (fig. 12), but not for all months. Anomalies were as large as increases of about $4.9^{\circ} \mathrm{C}$ (anomaly for mean monthly $T_{\text {max }}$ in May at the Lead weather station) and decreases of as much as $1.1{ }^{\circ} \mathrm{C}$ (anomalies for mean monthly $T_{\max }$ in October at the Custer weather station and in December at the Boerne weather station) (table 8).

\section{Climate and Hydrologic Response}

The hydrologic response to climate was based on application of the RRAWFLOW model to data for the Edwards and Madison aquifer sites (fig. 1; table 1). Output was daily springflow in cubic meters per second for all sites except the Bexar County Index Well, for which output was water-table level in meters. Periods used for calibration and validation of the RRAWFLOW model differ among stations (fig. 13), as described by Long and Mahler (2013), and include records from 2011 for some stations (table 1). Starting date of simulations differs among modeled sites (table 1), and simulations based on observations extend to December 31, 2010. The RRAWFLOW model simulations during calibration and validation periods indicate a good match between simulated response 

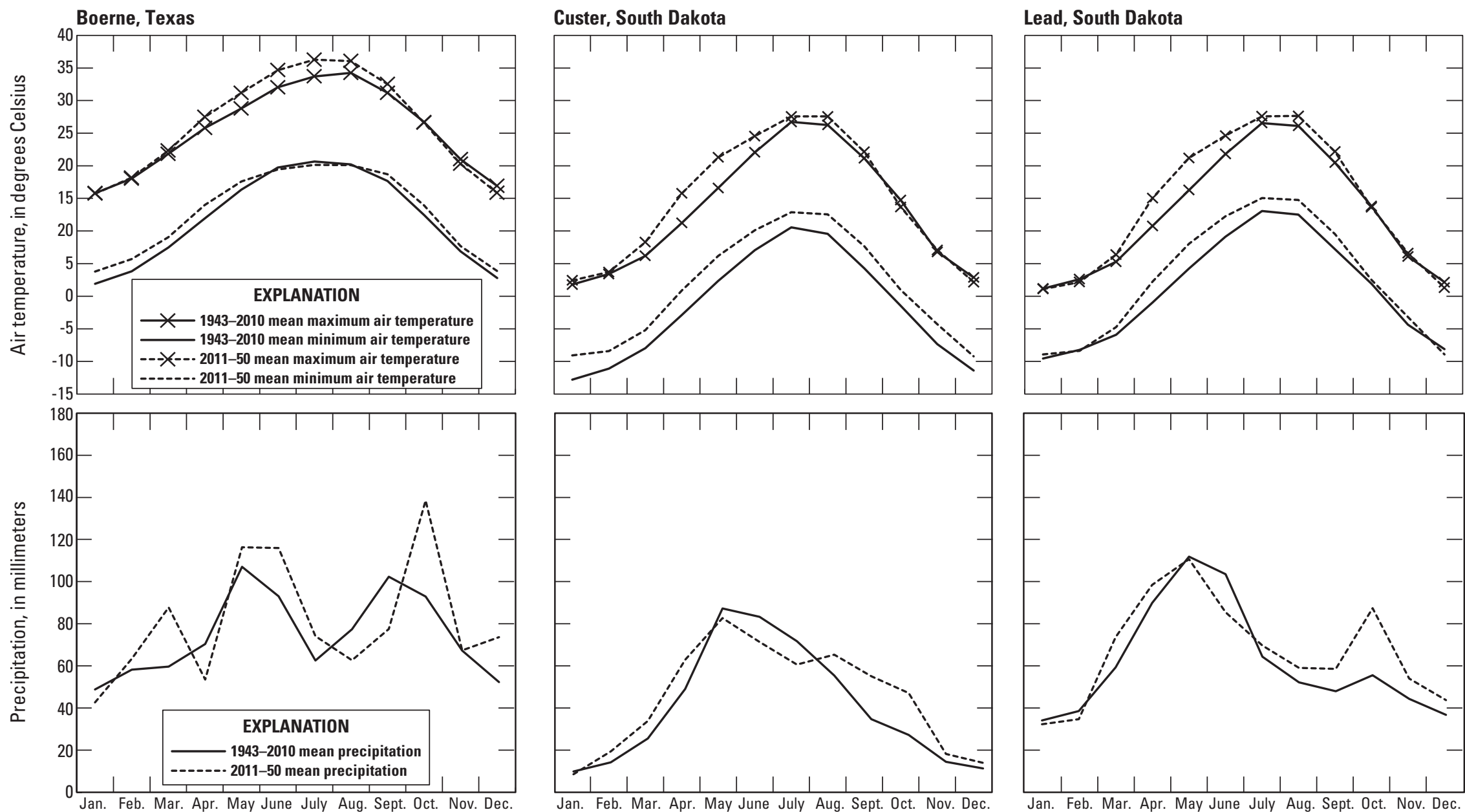

Month

Figure 12. Mean monthly precipitation and air temperature (daily maximum and minimum) of weather station records (1943-2010) and adjusted output from the Weather Research and Forecasting (WRF) model (2011-50) for selected weather stations. 
Table 8. Anomalies (mean monthly or mean annual for 2011-50 minus respective mean monthly or mean annual for 1943-2010) of climate variables for selected weather stations.

[NOAA, National Oceanic and Atmospheric Administration]

\begin{tabular}{|c|c|c|c|c|c|c|c|c|c|}
\hline \multirow{3}{*}{ Month } & \multicolumn{9}{|c|}{$\begin{array}{l}\text { Anomalies, computed as mean monthly or mean annual for 2011-50 minus } \\
\text { mean monthly or mean annual for 1943-2010 }\end{array}$} \\
\hline & \multicolumn{3}{|c|}{$\begin{array}{l}\text { Total precipitation }(P) \text { anomaly } \\
\text { (millimeters) at NOAA weather station }\end{array}$} & \multicolumn{3}{|c|}{$\begin{array}{c}\text { Mean of daily maximum air temperature } \\
\left(T_{\max }\right) \text { anomaly (degrees Celsius) at NOAA } \\
\text { weather station }\end{array}$} & \multicolumn{3}{|c|}{$\begin{array}{c}\text { Mean of daily minimum air temperature } \\
\left(T_{\text {min }}\right) \text { anomaly (degrees Celsius) at NOAA } \\
\text { weather station }\end{array}$} \\
\hline & $\begin{array}{l}\text { Boerne, } \\
\text { Texas }\end{array}$ & $\begin{array}{c}\text { Custer, } \\
\text { South Dakota }\end{array}$ & $\begin{array}{c}\text { Lead, } \\
\text { South Dakota }\end{array}$ & $\begin{array}{l}\text { Boerne, } \\
\text { Texas }\end{array}$ & $\begin{array}{c}\text { Custer, } \\
\text { South Dakota }\end{array}$ & $\begin{array}{c}\text { Lead, } \\
\text { South Dakota }\end{array}$ & $\begin{array}{l}\text { Boerne, } \\
\text { Texas }\end{array}$ & $\begin{array}{c}\text { Custer, } \\
\text { South Dakota }\end{array}$ & $\begin{array}{c}\text { Lead, } \\
\text { South Dakota }\end{array}$ \\
\hline January & -6 & -1 & -1 & -0.1 & 0.6 & -0.1 & 1.9 & 3.7 & 0.6 \\
\hline February & 5 & 5 & -3 & 0.1 & 0.3 & -0.4 & 1.9 & 2.7 & -0.2 \\
\hline March & 28 & 8 & 12 & 0.5 & 2.1 & 1.1 & 1.6 & 2.8 & 1.2 \\
\hline April & -17 & 14 & 9 & 1.7 & 4.5 & 4.3 & 2.1 & 3.8 & 3.2 \\
\hline May & 9 & -5 & 1 & 2.4 & 4.7 & 4.9 & 1.3 & 3.8 & 3.8 \\
\hline June & 23 & -12 & -14 & 2.6 & 2.5 & 2.8 & -0.3 & 3.1 & 3.1 \\
\hline July & 12 & -11 & 7 & 2.6 & 0.9 & 1.0 & -0.5 & 2.3 & 2.0 \\
\hline August & -15 & 10 & 10 & 1.8 & 1.3 & 1.5 & -0.1 & 3.0 & 2.3 \\
\hline September & -25 & 20 & 10 & 1.3 & 1.0 & 1.7 & 1.0 & 3.4 & 2.3 \\
\hline October & 46 & 20 & 32 & -0.1 & -1.1 & -0.2 & 1.5 & 2.5 & 0.6 \\
\hline November & 0 & 4 & 9 & -0.7 & 0.3 & 0.5 & 0.8 & 3.0 & 1.2 \\
\hline December & 21 & 3 & 6 & -1.1 & -0.7 & -0.8 & 1.0 & 2.2 & -0.8 \\
\hline Annual & 82 & 55 & 78 & 0.9 & 1.4 & 1.4 & 1.0 & 3.0 & 1.6 \\
\hline
\end{tabular}

and observation records, as described by Long and Mahler (2013). The RRAWFLOW model simulates hydrologic response given weather station records of air temperature and precipitation for times that precede recorded springflow or water-table level used for calibration and validation. Projected hydrologic response through 2050 requires input of $T_{\text {mean }}$ and $P$, as projected by the WRF model.

Hydrographs of annual mean springflow (fig. 13) for Comal Springs indicate the effect of precipitation on simulated annual mean springflow. For example, low precipitation in the 1950s was matched by distinct lows in Comal Springs springflow. Drought equivalent to the 1950s was not projected (2011-50) for this site, but annual mean water-table level of the Bexar County Index Well, below that observed in the 1950s (192.7 $\mathrm{m}$ in 1956), is projected for simulation years 2046 and 2047. Significance of trends is described in the section that follows, for which trends in springflow and watertable level during a historical baseline period are compared to projected springflow. For the Madison aquifer sites, the most marked change in hydrographs is for the Spearfish Creek site for which the hydrograph indicates little variability in projected springflow for 2011-50 relative to the record for simulated historical springflow before 2011.

\section{Baseline and Projected Climate and Hydrologic Response}

Climate trends for historical and projected climate have been described in the context of comparison of weather station observations from 1943 to 2010 to the WRF model output for 2011-50. For the CCVI analyses, comparison between sites was not required. Therefore, weather station observations preceding 1943 were used, if available, through 1975. Anomalies were computed as values for 2041-50 minus the associated baseline values for SOR-1975. Computed statistics include significance of monthly and annual trends, frequency and duration of daily events, and annual aridity indices for the Boerne, Custer, and Lead weather stations and associated RRAWFLOW model simulations.

\section{Trends}

Trends in time series of monthly mean and annual mean $T_{\max }$ and $T_{\text {min }}$ for SOR-1975 (table 9), 2011-50 (table 10), and SOR-2050 (table 11) at the Boerne, Custer, and Lead weather stations were used to generate factors used in the CCVI, such 

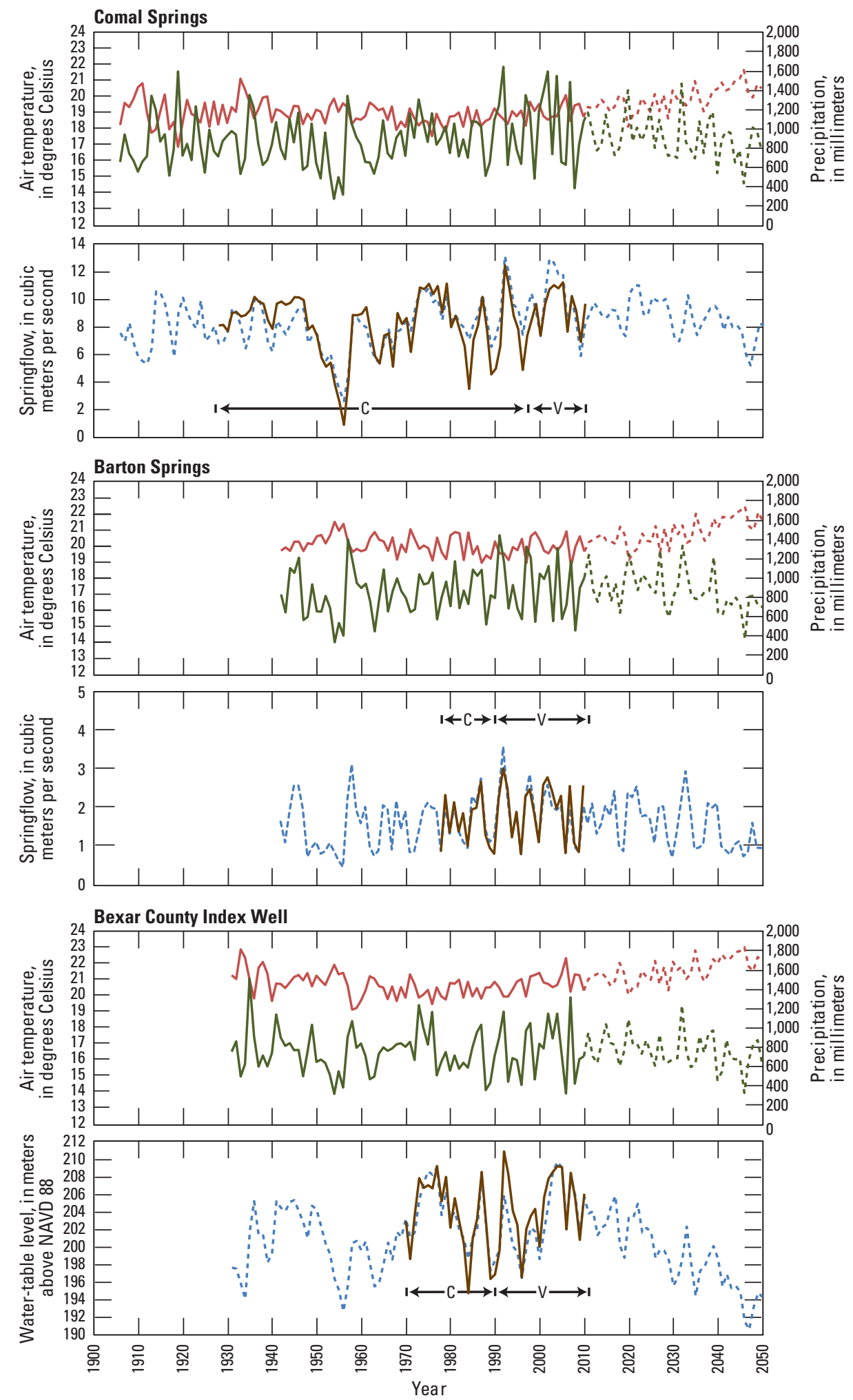

EXPLANATION

$1 \leftarrow C \rightarrow 1$ Calibration period

Observed air temperature

-..- Simulated air temperature

Simulated springflow or water-table level $\mathrm{I} \leftarrow \mathrm{V} \rightarrow \mathrm{I}$ Validation period

Observed precipitation

Simulated precipitation

Observed springflow or water-table level

Figure 13. Annual mean air temperature, annual total precipitation, and annual mean springflow or water-table level for Edwards and Madison aquifer sites based on observed weather station records, output from the Weather Research and Forecasting (WRF) model (simulated air temperature and precipitation), and output from the Rainfall-Response Aquifer and Watershed Flow (RRAWFLOW) model (simulated springflow or water-table level). 

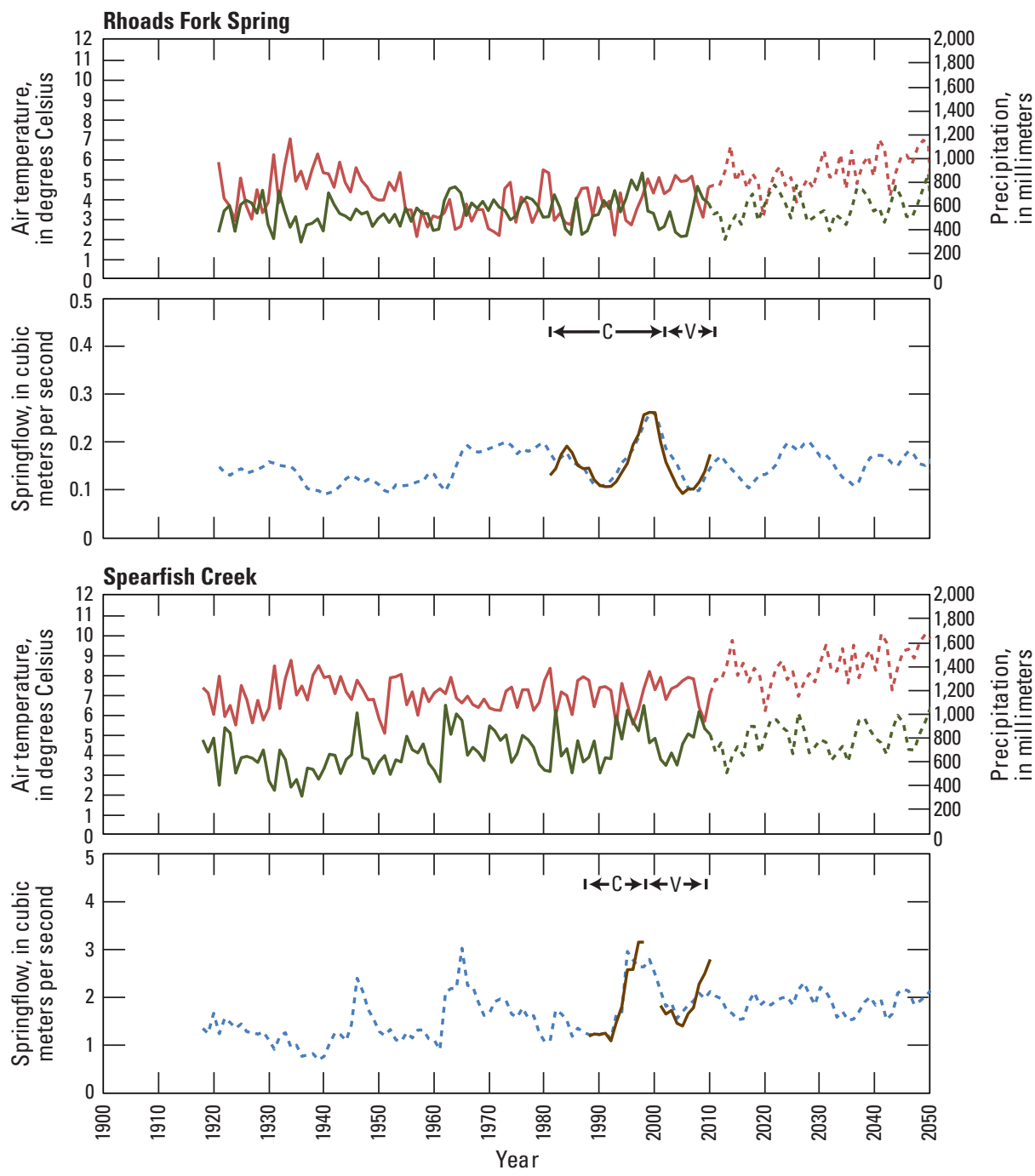

EXPLANATION

$1 \leftarrow C \rightarrow 1$ Calibration period
$1 \leftarrow V \rightarrow I$ Validation period

Observed air temperature
Observed precipitation

. . . . . . Simulated air temperature

Simulated springflow or water-table leve

Figure 13. Annual med

observed precipitation

(n) for Edwards and Madison aquifer sites based on observed weather station records, output from the Weather Research and Forecasting (WRF) model (simulated air temperature and precipitation), and output from the Rainfall-Response Aquifer and Watershed Flow (RRAWFLOW) model (simulated springflow or water-table level)._- Continued

as a species' physiological thermal and hydrological niches (factors C2aii and C2bii) (table 5). Trends also were evaluated for time series of monthly total and annual total $P$, and monthly mean and annual mean $T_{\text {mean }}$, which are also used in the CCVI in calculations of the aridity index. Significance of trends was determined on the basis of the Kendall-tau nonparametric test for monthly and annual time series.

The baseline period, SOR-1975, had few significant trends for all climate variables (table 9). The Lead weather station had an upward trend in annual total $P$, reflected by upward trends in monthly total $P$ for February, March, April, and December. The WRF model simulation period, 2011-50 (table 10), had upward trends in annual mean $T_{\text {mean }}, T_{\text {max }}$, and
$T_{\min }$ at all three weather stations and a downward trend in annual total $P$ for the Boerne weather station. Upward trends in annual mean $T_{\text {mean }}, T_{\text {max }}$, and $T_{\text {min }}$ at the Boerne weather station were reflected by upward trends for monthly means for April through September and November. The downward trend in annual total $\mathrm{P}$ was reflected by downward trends in monthly totals for June, July, and November. Upward trends in annual mean $T_{\text {mean }}, T_{\max }$, and $T_{\min }$ at the Custer and Lead weather stations were reflected by upward trends in monthly means for January, April, and November.

Trends in time series for SOR-2050 (table 11) were generally in agreement with trends for 1943-2050 (table 7). Trends differed in that the upward trend in annual $P$ for the 
Table 9. Statistical significance and direction of trends in monthly and annual precipitation and air temperatures at selected weather stations for the period spanning the start of weather station records (SOR) through 1975

[NOAA, National Oceanic and Atmospheric Administration; statistical significant trends have $p$-values less than or equal to 0.05 ; --, no significant trend; $\boldsymbol{\nabla}$, statistically significant downward trend; $\boldsymbol{\Delta}$, statistically significant upward trend]

\begin{tabular}{|c|c|c|c|c|c|c|c|c|c|c|c|c|c|}
\hline Statistic & January & February & March & April & May & June & July & August & September & October & November & December & Annual \\
\hline \multicolumn{14}{|c|}{ Boerne, Texas NOAA weather station (1906-75) } \\
\hline Total precipitation $(P)$ & -- & -- & -- & -- & -- & -- & $\nabla$ & -- & -- & -- & -- & -- & -- \\
\hline $\begin{array}{l}\text { Mean of daily mean air } \\
\text { temperature }\left(T_{\text {mean }}\right)\end{array}$ & $\boldsymbol{\nabla}$ & -- & -- & $\Delta$ & -- & -- & -- & -- & -- & -- & -- & -- & -- \\
\hline $\begin{array}{l}\text { Mean of daily maximum } \\
\text { air temperature }\left(T_{\max }\right)\end{array}$ & -- & -- & -- & -- & -- & -- & -- & $\boldsymbol{\nabla}$ & -- & -- & -- & -- & -- \\
\hline $\begin{array}{c}\text { Mean of daily minimum } \\
\text { air temperature }\left(T_{\min }\right)\end{array}$ & $\boldsymbol{\nabla}$ & -- & -- & -- & -- & -- & -- & - & -- & -- & -- & -- & -- \\
\hline \multicolumn{14}{|c|}{ Custer, South Dakota NOAA weather station (1943-75) } \\
\hline Total precipitation $(P)$ & -- & -- & -- & -- & -- & -- & -- & -- & -- & -- & -- & -- & -- \\
\hline $\begin{array}{l}\text { Mean of daily mean air } \\
\text { temperature }\left(T_{\text {mean }}\right)\end{array}$ & - & -- & - & - & -- & -- & - & - & - & - & -- & - & - \\
\hline $\begin{array}{l}\text { Mean of daily maximum } \\
\text { air temperature }\left(T_{\max }\right)\end{array}$ & -- & -- & -- & -- & -- & -- & -- & -- & -- & -- & -- & -- & -- \\
\hline $\begin{array}{c}\text { Mean of daily minimum } \\
\text { air temperature }\left(T_{\min }\right)\end{array}$ & -- & -- & -- & -- & -- & -- & -- & -- & -- & -- & -- & -- & -- \\
\hline \multicolumn{14}{|c|}{ Lead, South Dakota NOAA weather station (1918-75) } \\
\hline Total precipitation $(P)$ & -- & $\Delta$ & $\Delta$ & $\Delta$ & -- & -- & - & -- & -- & -- & -- & $\Delta$ & $\Delta$ \\
\hline $\begin{array}{l}\text { Mean of daily mean air } \\
\text { temperature }\left(T_{\text {mean }}\right)\end{array}$ & -- & -- & -- & -- & -- & -- & -- & -- & -- & -- & -- & -- & -- \\
\hline $\begin{array}{l}\text { Mean of daily maximum } \\
\text { air temperature }\left(T_{\max }\right)\end{array}$ & -- & -- & - & -- & -- & -- & -- & -- & -- & -- & -- & -- & -- \\
\hline $\begin{array}{c}\text { Mean of daily minimum } \\
\text { air temperature }\left(T_{\min }\right)\end{array}$ & -- & -- & -- & -- & -- & -- & -- & -- & -- & -- & -- & -- & -- \\
\hline
\end{tabular}


Table 10. Statistical significance and direction of trends in projected monthly and annual precipitation and air temperatures at selected weather stations for 2011-50.

[NOAA, National Oceanic and Atmospheric Administration; statistical significant trends have $p$-values less than or equal to 0.05 ; --, no significant trend; $\boldsymbol{\nabla}$, statistically significant downward trend; $\mathbf{\Lambda}$, statistically significant upward trend]

\begin{tabular}{|c|c|c|c|c|c|c|c|c|c|c|c|c|c|}
\hline Statistic & January & February & March & April & May & June & July & August & September & October & November & December & Annual \\
\hline \multicolumn{14}{|c|}{ Boerne, Texas NOAA weather station (2011-50) } \\
\hline Total precipitation $(P)$ & -- & -- & -- & -- & -- & $\nabla$ & $\nabla$ & -- & -- & -- & $\nabla$ & -- & $\nabla$ \\
\hline $\begin{array}{l}\text { Mean of daily mean air } \\
\text { temperature }\left(T_{\text {mean }}\right)\end{array}$ & -- & -- & -- & $\boldsymbol{\Delta}$ & $\boldsymbol{\Delta}$ & $\boldsymbol{\Delta}$ & $\boldsymbol{\Delta}$ & $\boldsymbol{\Delta}$ & $\boldsymbol{\Delta}$ & -- & $\boldsymbol{\Delta}$ & -- & $\boldsymbol{\Delta}$ \\
\hline $\begin{array}{l}\text { Mean of daily maximum } \\
\text { air temperature }\left(T_{\max }\right)\end{array}$ & -- & -- & -- & -- & $\Delta$ & $\boldsymbol{\Delta}$ & $\boldsymbol{\Delta}$ & $\boldsymbol{\Delta}$ & $\boldsymbol{\Delta}$ & -- & $\boldsymbol{\Delta}$ & -- & $\boldsymbol{\Delta}$ \\
\hline $\begin{array}{c}\text { Mean of daily minimum } \\
\text { air temperature }\left(T_{\min }\right)\end{array}$ & -- & -- & -- & $\boldsymbol{\Delta}$ & $\Delta$ & -- & $\boldsymbol{\Delta}$ & $\boldsymbol{\Delta}$ & $\boldsymbol{\Delta}$ & -- & $\Delta$ & -- & $\Delta$ \\
\hline \multicolumn{14}{|c|}{ Custer, South Dakota NOAA weather station (2011-50) } \\
\hline Total precipitation $(P)$ & -- & -- & -- & -- & -- & -- & -- & -- & -- & -- & -- & -- & -- \\
\hline $\begin{array}{l}\text { Mean of daily mean air } \\
\text { temperature }\left(T_{\text {mean }}\right)\end{array}$ & -- & -- & -- & $\boldsymbol{\Delta}$ & -- & -- & -- & -- & -- & -- & $\boldsymbol{\Delta}$ & -- & $\Delta$ \\
\hline $\begin{array}{l}\text { Mean of daily maximum } \\
\text { air temperature }\left(T_{\max }\right)\end{array}$ & $\Delta$ & -- & -- & $\boldsymbol{\Delta}$ & -- & -- & -- & -- & -- & -- & $\Delta$ & -- & $\boldsymbol{\Delta}$ \\
\hline $\begin{array}{c}\text { Mean of daily minimum } \\
\text { air temperature }\left(T_{\min }\right)\end{array}$ & -- & -- & -- & $\boldsymbol{\Delta}$ & -- & $\Delta$ & -- & -- & -- & -- & $\Delta$ & -- & $\Delta$ \\
\hline \multicolumn{14}{|c|}{ Lead, South Dakota NOAA weather station (2011-50) } \\
\hline Total precipitation $(P)$ & -- & -- & -- & -- & -- & -- & -- & -- & -- & -- & -- & -- & -- \\
\hline $\begin{array}{l}\text { Mean of daily mean air } \\
\text { temperature }\left(T_{\text {mean }}\right)\end{array}$ & -- & -- & -- & $\boldsymbol{\Delta}$ & -- & -- & -- & -- & -- & -- & $\Delta$ & -- & $\Delta$ \\
\hline $\begin{array}{l}\text { Mean of daily maximum } \\
\text { air temperature }\left(T_{\max }\right)\end{array}$ & $\Delta$ & -- & -- & $\boldsymbol{\Delta}$ & -- & -- & -- & -- & -- & -- & $\Delta$ & -- & $\Delta$ \\
\hline $\begin{array}{c}\text { Mean of daily minimum } \\
\text { air temperature }\left(T_{\min }\right)\end{array}$ & $\boldsymbol{\Delta}$ & -- & -- & $\boldsymbol{\Delta}$ & -- & -- & -- & -- & -- & -- & $\boldsymbol{\Delta}$ & -- & $\boldsymbol{\Delta}$ \\
\hline
\end{tabular}


Table 11. Statistical significance and direction of trends in monthly and annual precipitation and air temperatures at selected weather stations for the period spanning the start of the weather station record (SOR) through 2050.

[NOAA, National Oceanic and Atmospheric Administration; statistical significant trends have $p$-values less than or equal to 0.05 ; $\mathbf{\Lambda}$, statistically significant upward trend; --, no significant trend; $\nabla$, statistically significant downward trend]

\begin{tabular}{|c|c|c|c|c|c|c|c|c|c|c|c|c|c|}
\hline Statistic & January & February & March & April & May & June & July & August & September & October & November & December & Annual \\
\hline \multicolumn{14}{|c|}{ Boerne, Texas NOAA weather station (1906-2050) } \\
\hline Total precipitation $(P)$ & -- & -- & $\Delta$ & $\nabla$ & -- & $\Delta$ & -- & $\Delta$ & -- & $\Delta$ & -- & -- & $\Delta$ \\
\hline $\begin{array}{l}\text { Mean of daily mean air } \\
\text { temperature }\left(T_{\text {mean }}\right)\end{array}$ & -- & -- & -- & $\Delta$ & $\Delta$ & $\Delta$ & $\Delta$ & $\Delta$ & $\Delta$ & $\Delta$ & -- & -- & $\Delta$ \\
\hline $\begin{array}{l}\text { Mean of daily maximum } \\
\text { air temperature }\left(T_{\max }\right)\end{array}$ & -- & -- & -- & $\Delta$ & $\Delta$ & $\Delta$ & $\boldsymbol{\Delta}$ & $\Delta$ & $\Delta$ & -- & -- & -- & $\Delta$ \\
\hline $\begin{array}{l}\text { Mean of daily minimum } \\
\text { air temperature }\left(T_{\min }\right)\end{array}$ & -- & $\Delta$ & $\Delta$ & $\Delta$ & $\Delta$ & -- & -- & $\Delta$ & $\Delta$ & $\Delta$ & $\Delta$ & -- & $\Delta$ \\
\hline \multicolumn{14}{|c|}{ Custer, South Dakota NOAA weather station (1943-2050) } \\
\hline Total precipitation $(P)$ & -- & $\Delta$ & -- & $\Delta$ & -- & $\nabla$ & -- & -- & $\Delta$ & $\Delta$ & -- & -- & $\boldsymbol{\Delta}$ \\
\hline $\begin{array}{l}\text { Mean of daily mean air } \\
\text { temperature }\left(T_{\text {mean }}\right)\end{array}$ & $\Delta$ & $\Delta$ & $\Delta$ & $\Delta$ & $\Delta$ & $\Delta$ & $\Delta$ & $\Delta$ & $\Delta$ & $\Delta$ & $\Delta$ & $\Delta$ & $\Delta$ \\
\hline $\begin{array}{l}\text { Mean of daily maximum } \\
\text { air temperature }\left(T_{\max }\right)\end{array}$ & $\Delta$ & -- & $\Delta$ & $\Delta$ & $\Delta$ & $\Delta$ & $\boldsymbol{\Delta}$ & $\Delta$ & $\Delta$ & $\nabla$ & -- & -- & $\Delta$ \\
\hline $\begin{array}{l}\text { Mean of daily minimum } \\
\text { air temperature }\left(T_{\min }\right)\end{array}$ & $\Delta$ & $\Delta$ & $\Delta$ & $\boldsymbol{\Delta}$ & $\Delta$ & $\boldsymbol{\Delta}$ & $\boldsymbol{\Delta}$ & $\Delta$ & $\boldsymbol{\Delta}$ & $\Delta$ & $\boldsymbol{\Delta}$ & $\Delta$ & $\Delta$ \\
\hline \multicolumn{14}{|c|}{ Lead, South Dakota NOAA weather station (1918-2050) } \\
\hline Total precipitation $(P)$ & -- & $\Delta$ & $\Delta$ & $\Delta$ & $\Delta$ & $\boldsymbol{\nabla}$ & -- & -- & $\Delta$ & $\Delta$ & $\Delta$ & $\Delta$ & $\Delta$ \\
\hline $\begin{array}{l}\text { Mean of daily mean air } \\
\text { temperature }\left(T_{\text {mean }}\right)\end{array}$ & -- & -- & $\Delta$ & $\Delta$ & $\Delta$ & $\Delta$ & $\Delta$ & $\boldsymbol{\Delta}$ & $\Delta$ & -- & -- & -- & $\Delta$ \\
\hline $\begin{array}{l}\text { Mean of daily maximum } \\
\text { air temperature }\left(T_{\max }\right)\end{array}$ & -- & -- & $\Delta$ & $\Delta$ & $\Delta$ & $\Delta$ & -- & -- & $\Delta$ & -- & -- & -- & $\Delta$ \\
\hline $\begin{array}{l}\text { Mean of daily minimum } \\
\text { air temperature }\left(T_{\min }\right)\end{array}$ & -- & -- & $\Delta$ & $\Delta$ & $\Delta$ & $\Delta$ & $\Delta$ & $\Delta$ & $\Delta$ & -- & $\Delta$ & -- & $\Delta$ \\
\hline
\end{tabular}


Boerne weather station was not significant over the period 1943-2050, but was significant over the period SOR-2050. Trends in annual mean $T_{\text {mean }}, T_{\max }$, and $T_{\text {min }}$ were upward for all weather stations and these trends were reflected by the positive anomalies in $T_{\text {mean }}, T_{\max }$, and $T_{\min }$ for 2041-50 relative to SOR-1975 (table 12). Trends in annual $P$ were upward for all weather stations, consistent with positive anomalies in mean annual $P$ for 2041-50 for the Custer and Lead weather stations, but not consistent with the negative anomaly in mean annual $P$ for the Boerne weather station (table 12). Trends in April $P$ for SOR-2050 were downward for the Boerne weather station (table 11); however, trends were upward for March, June, August, and October, resulting in upward trends in annual $P$. Trends in June $P$ for SOR-2050 were downward for the Custer and Boerne weather stations, which was a month that typically received higher amounts of precipitation than other months (fig. 12). However, upward trends in other months counteract the downward trend in June, with a resultant upward trend in annual $P$ for SOR-2050 for the Custer and Boerne weather stations.

Trends in RRAWFLOW model output generally were consistent between monthly and annual means for each site (table 13). For the baseline period, SOR-1975, no trends in springflow or water-table level were significant except for Spearfish Creek, which had an upward trend for all monthly and annual springflows, and for Rhoads Fork Spring, which had an upward trend for July springflow. For the projected climate period, 2011-50, annual springflow or water-table level had a significant downward trend for all Edwards aquifer sites and no significant trend for Madison aquifer sites. For SOR-2050, Comal Springs, Spearfish Creek, and Rhoads Fork Spring had upward trends in annual and monthly springflows. In contrast, trends in annual and monthly springflow were not significant for Barton Springs, and downward trends in annual and monthly water-table levels (with the exception of April) were indicated for the Bexar County Index Well.

\section{Frequencies and Extremes of Events}

Frequencies of extreme events were used to score the CCVI factors for physiological thermal and hydrologic niche (table 5). Frequency of climate or hydrologic events can be expressed as a percentage associated with an exceedance value. For example, if 20 percent is associated with an exceedance value of $15^{\circ} \mathrm{C}$, it means that air temperature exceeded $15^{\circ} \mathrm{C}$ for 20 percent of the record. Exceedance values were computed for $P, T_{\max }$, and $T_{\text {min }}$ for the Boerne, Lead, and Custer weather stations (table 14), and exceedance values for daily springflow or water-table level at Edwards and Madison aquifer sites (table 15). Anomalies were computed as the exceedance value for 2041-50 minus the value for SOR-1975 for specified percentages.

Many days in weather station records or the WRF model simulation had zero precipitation. This is reflected in zero entries for exceedance values for $P$ values reported in table 14 . For the period SOR-1975, zero precipitation was recorded 79,
68, and 77 percent of the time at the Boerne, Lead, and Custer weather stations, respectively. For the period 2041-50, zero precipitation was projected 64,63 , and 76 percent of the time at the Boerne, Lead, and Custer weather stations, respectively. In summary, the number of days with zero precipitation were similar for the two periods for the Lead and Custer weather station locations, but at the Boerne weather station location were more frequent in SOR-1975 than the projected period 2041-50.

Exceedance values for air temperature (table 14) indicate anomalies on the order of 1 to $3{ }^{\circ} \mathrm{C}$ for the Boerne and Lead weather station locations. Anomalies for the Custer weather station location are more extreme, particularly those associated with $T_{m i n}$, and are on the order of increases of 5 to $6{ }^{\circ} \mathrm{C}$ for all categories for the percent of time exceeded. Anomalies for the Custer weather station for $T_{\max }$ are on the order of increases of 2 to $3{ }^{\circ} \mathrm{C}$.

Exceedance values for springflow or water-table level (table 15) can be categorized as low flow (those flows exceeded 80 to 90 percent of the time), median flow (those exceeded 50 percent of the time), and high-flow events (those exceeded 10 to 20 percent of the time). Exceedance values indicate increases in projected low flow, represented as positive anomalies, for Madison aquifer sites and Barton Springs, decreases in low water-table levels for the Bexar County Index Well, and increases to slight decreases in low flow for Comal Springs. High flows were projected to decrease for Edwards aquifer sites, increase for Spearfish Creek, and slight changes are indicated for Rhoads Fork Spring. Exceedance values for 50 percent indicate decreased flows and water-table levels for Edwards aquifer sites, and increased flows for Madison aquifer sites.

The CCVI factors also were scored on the basis of extremes in precipitation and air temperature. A metric of extremes, used for Madison aquifer sites, was the number of days that maximum air temperature exceeded $36{ }^{\circ} \mathrm{C}$ and the maximum number of consecutive days in a year with a mean daily air temperature that exceeded $36^{\circ} \mathrm{C}$ (fig. 14). Another metric of extremes, used for all sites, was computed as the mean July $T_{\max }$ minus mean January $T_{\min }$, for SOR-1975 (table 16).

\section{Aridity Index}

The aridity index for a given year is based on the ratio of annual precipitation to annual potential evapotranspiration (United Nations Environment Programme, 1997; Parsons and Abrahams, 2009), and computations include monthly total $P$ and monthly mean $T_{\text {mean }}$. Monthly potential evapotranspiration was set to zero if monthly mean $T_{\text {mean }}$ was less than $0{ }^{\circ} \mathrm{C}$ and otherwise was computed using the method from Hamon (1961). Calculations of potential evapotranspiration required estimates of the length of day, which were computed using the methodology described by Dingman (2002). An aridity index approaching 0.0 indicates more arid conditions (annual 
Table 12. Climate anomalies, computed as mean monthly or mean annual for 2041-50 minus mean monthly or mean annual for start of record (SOR) through 1975 at selected weather stations.

[NOAA, National Oceanic and Atmospheric Administration]

\begin{tabular}{|c|c|c|c|c|c|c|c|c|c|c|c|c|}
\hline \multirow{3}{*}{ Month } & \multicolumn{12}{|c|}{$\begin{array}{c}\text { Anomalies, computed as mean monthly or mean annual for 2041-50 minus mean monthly or mean annual anomaly for start of record (SOR) } \\
\text { through } 1975\end{array}$} \\
\hline & \multicolumn{3}{|c|}{$\begin{array}{l}\text { Total precipitation }(P) \text { anomaly } \\
\text { (millimeters) at NOAA weather } \\
\text { station }\end{array}$} & \multicolumn{3}{|c|}{$\begin{array}{c}\text { Mean of daily mean air- } \\
\text { temperature }\left(T_{\text {mean }}\right) \text { anomaly } \\
\text { (degrees Celsius) at NOAA } \\
\text { weather station }\end{array}$} & \multicolumn{3}{|c|}{$\begin{array}{c}\text { Mean of daily maximum air- } \\
\text { temperature }\left(T_{\max }\right) \text { anomaly } \\
\text { (degrees Celsius) at NOAA } \\
\text { weather station }\end{array}$} & \multicolumn{3}{|c|}{$\begin{array}{c}\text { Mean of daily minimum air- } \\
\text { temperature }\left(T_{\text {min }}\right) \text { anomaly } \\
\text { (degrees Celsius) at NOAA } \\
\text { weather station }\end{array}$} \\
\hline & $\begin{array}{l}\text { Boerne, } \\
\text { Texas }\end{array}$ & $\begin{array}{l}\text { Custer, } \\
\text { South } \\
\text { Dakota }\end{array}$ & $\begin{array}{l}\text { Lead, } \\
\text { South } \\
\text { Dakota }\end{array}$ & $\begin{array}{l}\text { Boerne, } \\
\text { Texas }\end{array}$ & $\begin{array}{l}\text { Custer, } \\
\text { South } \\
\text { Dakota }\end{array}$ & $\begin{array}{l}\text { Lead, } \\
\text { South } \\
\text { Dakota }\end{array}$ & $\begin{array}{l}\text { Boerne, } \\
\text { Texas }\end{array}$ & $\begin{array}{l}\text { Custer, } \\
\text { South } \\
\text { Dakota }\end{array}$ & $\begin{array}{l}\text { Lead, } \\
\text { South } \\
\text { Dakota }\end{array}$ & $\begin{array}{l}\text { Boerne, } \\
\text { Texas }\end{array}$ & $\begin{array}{l}\text { Custer, } \\
\text { South } \\
\text { Dakota }\end{array}$ & $\begin{array}{l}\text { Lead, } \\
\text { South } \\
\text { Dakota }\end{array}$ \\
\hline January & -11.7 & -4.6 & -6.5 & 1.1 & 5.5 & 3.0 & 0.8 & 2.8 & 2.3 & 1.4 & 7.8 & 3.5 \\
\hline February & 1.2 & 5.4 & 6.9 & 1.1 & 4.2 & 2.4 & 0.5 & 2.0 & 1.8 & 1.5 & 6.5 & 3.0 \\
\hline March & 38.8 & 8.9 & 31.3 & 1.4 & 3.4 & 1.4 & 0.9 & 2.7 & 1.4 & 1.9 & 4.2 & 1.4 \\
\hline April & -24.0 & 20.3 & 16.0 & 2.7 & 6.5 & 5.5 & 2.6 & 6.8 & 6.3 & 2.8 & 6.6 & 5.2 \\
\hline May & -7.8 & -0.3 & 12.6 & 3.0 & 5.8 & 5.0 & 4.2 & 5.8 & 5.5 & 2.0 & 5.7 & 4.8 \\
\hline June & 23.0 & -19.4 & -9.2 & 2.0 & 3.9 & 2.9 & 3.8 & 2.9 & 2.5 & 0.5 & 4.4 & 3.2 \\
\hline July & -3.2 & -0.1 & 4.2 & 1.7 & 2.9 & 1.6 & 3.7 & 1.1 & 0.8 & 0.3 & 4.4 & 2.4 \\
\hline August & -13.3 & 21.6 & 28.5 & 1.9 & 3.0 & 1.7 & 2.6 & 1.2 & 1.1 & 0.7 & 4.7 & 2.5 \\
\hline September & -23.2 & 25.7 & 10.3 & 1.9 & 3.4 & 1.9 & 2.1 & 1.7 & 1.7 & 1.6 & 5.7 & 2.8 \\
\hline October & 5.5 & 27.0 & 55.1 & 1.3 & 2.0 & 0.6 & 0.8 & -0.5 & 0.5 & 1.6 & 4.9 & 1.4 \\
\hline November & 0.7 & 5.7 & 17.2 & 1.3 & 3.8 & 2.3 & 1.0 & 1.7 & 2.2 & 1.6 & 5.9 & 2.5 \\
\hline December & 6.6 & 8.9 & 23.0 & 0.5 & 0.9 & -1.3 & 0.0 & -1.7 & -1.4 & 1.0 & 3.1 & -1.4 \\
\hline Annual & -7.6 & 99.1 & 189.3 & 1.7 & 3.8 & 2.2 & 1.9 & 2.2 & 2.1 & 1.4 & 5.3 & 2.6 \\
\hline
\end{tabular}


Table 13. Statistical significance and direction of trends in monthly mean and annual mean springflow or water-table level at Edwards and Madison aquifer sites based on output from the Rainfall-Response Aquifer and Watershed Flow (RRAWFLOW) model.

[Statistical significant trends have $p$-values less than or equal to 0.05 .; --, no significant trend; $\mathbf{\Lambda}$, statistically significant upward trend; $\boldsymbol{\nabla}$, statistically significant downward trend]

\begin{tabular}{|c|c|c|c|c|c|c|c|c|c|c|c|c|c|}
\hline Aquifer site & January & February & March & April & May & June & July & August & September & October & November & December & Annual \\
\hline \multicolumn{14}{|c|}{ Start of record through 1975} \\
\hline Comal Springs & -- & -- & -- & -- & -- & -- & -- & -- & -- & -- & -- & -- & -- \\
\hline Barton Springs & -- & -- & -- & -- & -- & -- & -- & -- & -- & -- & -- & -- & -- \\
\hline Bexar County Index Well & -- & -- & -- & -- & -- & -- & -- & -- & -- & -- & -- & -- & -- \\
\hline Spearfish Creek & $\Delta$ & $\Delta$ & $\Delta$ & $\Delta$ & $\Delta$ & $\Delta$ & $\boldsymbol{\Delta}$ & $\Delta$ & $\boldsymbol{\Delta}$ & $\Delta$ & $\boldsymbol{\Delta}$ & $\Delta$ & $\boldsymbol{\Delta}$ \\
\hline Rhoads Fork Spring & -- & -- & -- & -- & -- & -- & $\boldsymbol{\Delta}$ & -- & -- & -- & -- & -- & -- \\
\hline \multicolumn{14}{|c|}{$2011-50$} \\
\hline Comal Springs & $\nabla$ & $\nabla$ & $\nabla$ & $\nabla$ & $\boldsymbol{\nabla}$ & $\nabla$ & $\boldsymbol{\nabla}$ & $\boldsymbol{\nabla}$ & $\boldsymbol{\nabla}$ & $\nabla$ & $\boldsymbol{\nabla}$ & $\nabla$ & $\boldsymbol{\nabla}$ \\
\hline Barton Springs & $\boldsymbol{\nabla}$ & $\boldsymbol{\nabla}$ & $\boldsymbol{\nabla}$ & $\nabla$ & $\boldsymbol{\nabla}$ & $\boldsymbol{\nabla}$ & $\boldsymbol{\nabla}$ & $\nabla$ & $\boldsymbol{\nabla}$ & $\nabla$ & $\nabla$ & $\nabla$ & $\boldsymbol{\nabla}$ \\
\hline Bexar County Index Well & $\nabla$ & $\boldsymbol{\nabla}$ & $\boldsymbol{\nabla}$ & $\nabla$ & $\boldsymbol{\nabla}$ & $\nabla$ & $\boldsymbol{\nabla}$ & $\boldsymbol{\nabla}$ & $\boldsymbol{\nabla}$ & $\nabla$ & $\boldsymbol{\nabla}$ & $\nabla$ & $\boldsymbol{\nabla}$ \\
\hline Spearfish Creek & -- & -- & -- & -- & -- & -- & -- & -- & -- & -- & -- & -- & -- \\
\hline Rhoads Fork Spring & -- & -- & -- & -- & -- & -- & -- & -- & -- & -- & -- & -- & -- \\
\hline \multicolumn{14}{|c|}{ Start of record through 2050} \\
\hline Comal Springs & $\Delta$ & $\Delta$ & $\Delta$ & $\Delta$ & $\Delta$ & $\Delta$ & $\Delta$ & $\Delta$ & $\Delta$ & $\Delta$ & $\Delta$ & $\Delta$ & $\Delta$ \\
\hline Barton Springs & -- & -- & -- & -- & -- & -- & -- & -- & -- & -- & -- & -- & -- \\
\hline Bexar County Index Well & $\nabla$ & $\nabla$ & $\boldsymbol{\nabla}$ & -- & $\nabla$ & $\nabla$ & $\boldsymbol{\nabla}$ & $\boldsymbol{\nabla}$ & $\boldsymbol{\nabla}$ & $\nabla$ & $\boldsymbol{\nabla}$ & $\nabla$ & $\boldsymbol{\nabla}$ \\
\hline Spearfish Creek & $\Delta$ & $\Delta$ & $\Delta$ & $\Delta$ & $\Delta$ & $\Delta$ & $\Delta$ & $\Delta$ & $\Delta$ & $\Delta$ & $\Delta$ & $\Delta$ & $\Delta$ \\
\hline Rhoads Fork Spring & $\boldsymbol{\Delta}$ & $\Delta$ & $\boldsymbol{\Delta}$ & $\boldsymbol{\Delta}$ & $\boldsymbol{\Delta}$ & $\boldsymbol{\Delta}$ & $\boldsymbol{\Delta}$ & $\boldsymbol{\Delta}$ & $\boldsymbol{\Delta}$ & $\boldsymbol{\Delta}$ & $\boldsymbol{\Delta}$ & $\Delta$ & $\Delta$ \\
\hline
\end{tabular}


Table 14. Exceedance values of daily climate variables for selected weather stations, on the basis of observational records for the start of record (SOR) through 1975 and output from the Weather Research and Forecasting (WRF) model for $2041-50$.

[NOAA, National Oceanic and Atmospheric Administration; anomalies are computed as the exceedance value for 2041-50 minus the associated exceedance value for start of weather station record through 1975]

\begin{tabular}{|c|c|c|c|c|c|c|c|c|c|}
\hline \multirow{2}{*}{$\begin{array}{c}\text { Percentage } \\
\text { of time } \\
\text { exceeded }\end{array}$} & \multicolumn{3}{|c|}{$\begin{array}{c}\text { Boerne, Texas } \\
\text { NOAA weather station }\end{array}$} & \multicolumn{3}{|c|}{$\begin{array}{l}\text { Custer, South Dakota } \\
\text { NOAA weather station }\end{array}$} & \multicolumn{3}{|c|}{$\begin{array}{l}\text { Lead, South Dakota } \\
\text { NOAA weather station }\end{array}$} \\
\hline & $1906-75$ & 2041-50 & Anomaly & $1943-75$ & 2041-50 & Anomaly & $1918-75$ & 2041-50 & Anomaly \\
\hline \multicolumn{10}{|c|}{ Daily total precipitation $(P)$, in millimeters } \\
\hline 10 & 4.6 & 5.5 & 0.9 & 3.3 & 4.0 & 0.7 & 5.1 & 6.7 & 1.6 \\
\hline 20 & 0.5 & 3.3 & 2.8 & 0.5 & 0.8 & 0.3 & 1.8 & 3.3 & 1.6 \\
\hline 50 & 0.0 & 0.0 & 0.0 & 0.0 & 0.0 & 0.0 & 0.0 & 0.0 & 0.0 \\
\hline 80 & 0.0 & 0.0 & 0.0 & 0.0 & 0.0 & 0.0 & 0.0 & 0.0 & 0.0 \\
\hline 90 & 0.0 & 0.0 & 0.0 & 0.0 & 0.0 & 0.0 & 0.0 & 0.0 & 0.0 \\
\hline \multicolumn{10}{|c|}{ Daily maximum air temperature $\left(T_{\max }\right)$, in degrees Celsius } \\
\hline 10 & 35.00 & 37.73 & 2.73 & 27.78 & 28.84 & 1.06 & 27.78 & 28.81 & 1.03 \\
\hline 20 & 32.80 & 36.02 & 3.22 & 23.89 & 25.72 & 1.84 & 24.44 & 25.75 & 1.30 \\
\hline 50 & 26.70 & 28.26 & 1.56 & 12.78 & 16.40 & 3.62 & 12.78 & 15.87 & 3.09 \\
\hline 80 & 18.90 & 19.52 & 0.62 & 3.33 & 5.53 & 2.19 & 2.22 & 4.74 & 2.52 \\
\hline 90 & 15.00 & 15.79 & 0.79 & -1.11 & 0.81 & 1.92 & -1.67 & 0.08 & 1.75 \\
\hline \multicolumn{10}{|c|}{ Daily minimum air temperature $\left(T_{\min }\right)$, degrees Celsius } \\
\hline 10 & 21.10 & 21.20 & 0.10 & 8.89 & 13.80 & 4.91 & 13.89 & 15.95 & 2.06 \\
\hline 20 & 20.00 & 20.17 & 0.17 & 6.11 & 11.15 & 5.04 & 10.00 & 13.30 & 3.30 \\
\hline 50 & 13.90 & 15.36 & 1.46 & -2.78 & 2.80 & 5.58 & 1.11 & 4.21 & 3.10 \\
\hline 80 & 3.90 & 6.63 & 2.73 & -11.67 & -5.42 & 6.25 & -7.22 & -4.33 & 2.89 \\
\hline 90 & 0.00 & 2.86 & 2.86 & -16.67 & -11.79 & 4.88 & -12.22 & -10.76 & 1.46 \\
\hline
\end{tabular}

precipitation approaches zero and is less than potential evapotranspiration), with wetter conditions as the aridity index approaches 1.0 (annual precipitation approaches or exceeds the value of potential evapotranspiration). Aridity index has four classifications (Parsons and Abrahams, 2009):

1. Hyperarid: less than 0.05

2. Arid: 0.05 to 0.20

3. Semiarid: 0.20 to 0.50

4. Dry-subhumid: 0.50 to 0.65

Aridity index was computed for the Boerne, Custer, and Lead weather stations for the SOR through 2050 (fig. 15). The percentage of years for each of the four classifications was computed for the time periods SOR-2050, SOR-1975, and 2041-50 (table 17). No years in these three time periods were classified as arid or hyperarid for any of the three stations. The percentage of years that were classified as semiarid is projected to decrease from SOR-1975 to 2041-50 for all weather stations. The dominant classification for the Boerne weather station is dry-subhumid, and the percentage of years classified as dry-subhumid is projected to increase from SOR-1975 to 2041-50. Approximately 60 percent of years SOR-1975 for the Custer and Lead weather stations do not fall within the aridity index classification. The percentage of years classified as dry-subhumid is projected to increase for the Custer weather station and decrease for the Lead weather station. The trend in aridity index for the Custer weather station (fig. 15) is similar to the trend for the Lead weather station for historical climate, but commonly ( 80 percent of years) is lower (more arid) than the Lead weather station for projected climate of 2011-50.

\section{Species Vulnerability to Projected Climate and Hydrologic Response}

Climatic and hydrologic information was used to determine scores for 7 of the 26 factors defined in the CCVI (A1, A2, C2ai, C2aii, C2bi, C2bii, and C2c; table 5). This allows the CCVI to quantify species vulnerability to climatic and hydrologic variability and change from the RRAWFLOW model projections for the hydrological features that the species depend on. Factor scores and detailed justifications for assigning scores for each species evaluated are in supplemental table S1-2, and a summary of the results are in table 18 . 


\section{Species Vulnerability}

All of the 16 species evaluated for the Balcones Escarpment region occurred in either Comal or Barton Springs. One-half of the species were stygobites, six of the species occurred in the springs, and two of the species were dominant riparian relict plants (supplemental table S1-2). Two of the plant species in the Balcones Escarpment region, Ehretia anacua and Cabomba caroliniana, were evaluated because of their importance as habitat for two endangered species from Comal Springs, Heterelmis comalensis and Etheostoma fonticola, respectively. However, Ehretia anacua and Cabomba caroliniana are not listed in supplemental table S1-1 because they are not species of conservation concern. As described in the "Species Assessment" section, the stygobites were not scored as such in the CCVI score sheet because of the rapid response of these karst systems to surface conditions. The RRAWFLOW model output for the Bexar County Index Well confirmed this with projections of downward trends in watertable level across all months for 2011-50 (table 13).

One salamander in the Balcones Escarpment region was scored as highly vulnerable, four spring and riparian plants as well as two invertebrates were scored as not vulnerable/ presumed stable, and the remaining nine species were scored as moderately vulnerable (table 18). For all species in the region, the projected air temperature increase at the Boerne weather station, as assessed by the difference between mean annual $T_{\text {mean }}$ between 1906-75 and 2041-50 (factor A1, table 19), was only $1.7^{\circ} \mathrm{C}$ - the lowest severity category for exposure to air temperature change in the CCVI. For the period 2011-50, trends in mean monthly $T_{\text {mean }}$ were projected to have an increasing trend during 7 months whereas precipitation was projected to decrease during 3 months (table 10). The WRF model projects a slight increase of 0.1 percent in the moisture index (factor A2, table 19), which is the lowest severity category for the CCVI.

All of the species that were scored as highly or moderately vulnerable in the Balcones Escarpment region are obligate aquatic cave or spring species in habitats that have undergone substantial historical hydrological variation (factor C2bi, table 19). Recent evidence indicates that many of these species are affected negatively by extremely low flows that lead to decreased dissolved oxygen concentrations and increased water temperature (Woods and others, 2010; BIOWEST, Inc., 2011; Gillespie, 2011; RECON Environmental, Inc., and others, 2012), or by extremely high flows that lead to habitat loss (RECON Environmental, Inc., and others, 2012). Consequently, the RRAWFLOW model estimates of projected springflow and water-table level for the springs and Bexar County Index Well were invaluable for scoring vulnerability of these species. Mean monthly precipitation is projected to decrease for only 6 months of the year, mostly during the hot summer months (table 12). However, the RRAWFLOW model projects decreased mean monthly springflow during each month for the period 2011-50 (table 13). In Comal Springs, median springflow is projected to decrease from 7.71 


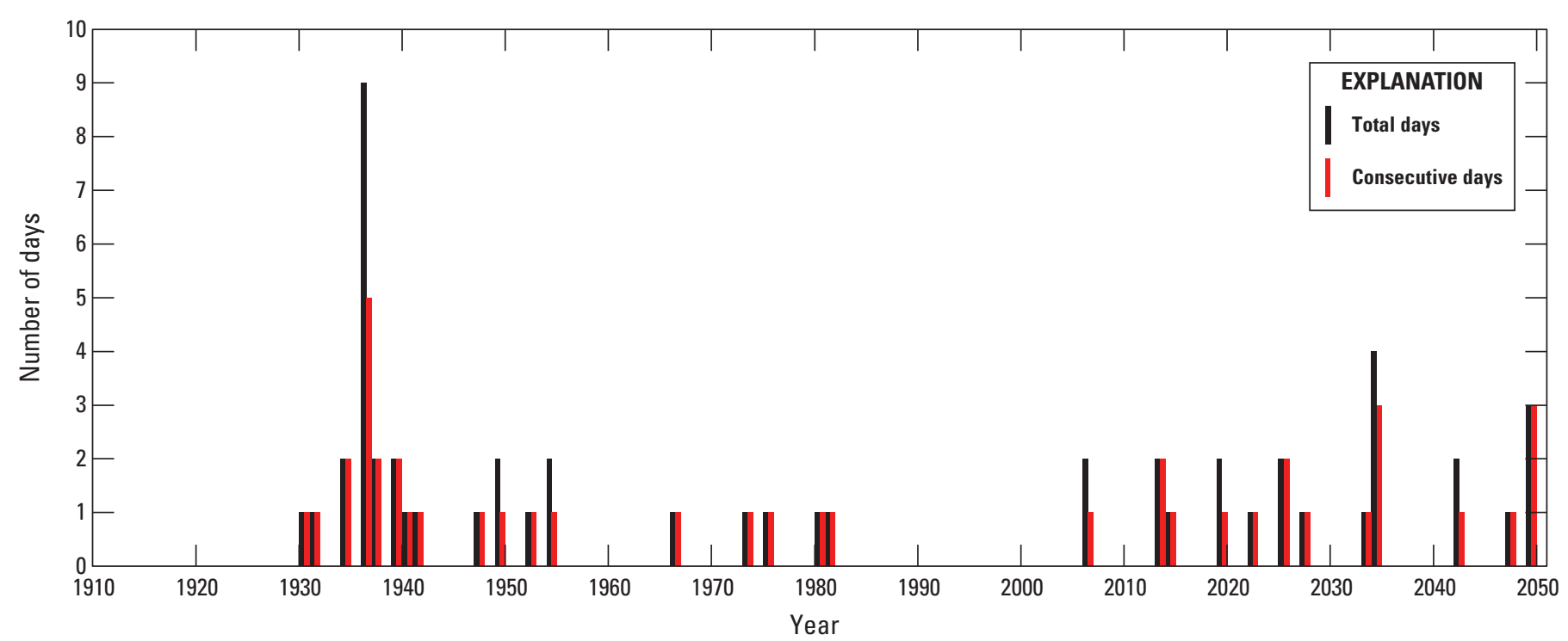

Figure 14. Number of days and consecutive days in a year that the maximum daily air temperature exceeded 36 degrees Celsius at the Lead, South Dakota, weather station. (Data records begin in 1918).

Table 16. Range in annual temperature measured as July mean daily maximum air temperature minus January mean daily minimum air temperature for start of weather station record (SOR) through 1975 for selected weather stations.

[NOAA, National Oceanic and Atmospheric Administration]

\begin{tabular}{lccc}
\hline \multirow{2}{*}{ Statistic } & \multicolumn{3}{c}{ Air temperature, in degrees Celsius (SOR-1975) } \\
\cline { 2 - 4 } & $\begin{array}{c}\text { Boerne, Texas } \\
\text { NOAA weather station }\end{array}$ & $\begin{array}{c}\text { Custer, South Dakota } \\
\text { NOAA weather station }\end{array}$ & $\begin{array}{c}\text { Lead, South Dakota } \\
\text { NOAA weather station }\end{array}$ \\
\hline $\begin{array}{l}\text { Mean of maximum daily air } \\
\text { temperature }\left(T_{\max }\right) \text { for July }\end{array}$ & 34.0 & 26.7 & 27.1 \\
$\begin{array}{c}\text { Mean of minimum daily air } \\
\text { temperature }\left(T_{\min }\right) \text { for January }\end{array}$ & 2.9 & -14.8 & -10.0 \\
\begin{tabular}{l} 
Range \\
\hline
\end{tabular} & 31.1 & 41.6 & 37.1 \\
\hline
\end{tabular}

for 1906-75 to $7.69 \mathrm{~m}^{3} / \mathrm{s}$ for 2041-50 (0.2 percent change), whereas median springflow at Barton Springs is projected to decrease from 1.23 for $1942-75$ to $0.91 \mathrm{~m}^{3} / \mathrm{s}$ for $2041-50$ (30 percent change) (table 15). Water-table levels for the Bexar County Index Well are also projected to decrease, with median water-table levels decreasing from 200.7 for 1931-75 to $194.5 \mathrm{~m}$ for 2041-50, a change of 6.2 meters (table 15), with projected annual mean water-table levels falling below that observed in the 1950s (192.7 $\mathrm{m}$ in 1956) for simulation years 2046-47 (fig. 13).

Projections of significant decreases in springflow and water-table levels led to scoring all of the Barton Springs and aquifer species as increase or greatly increase for hydrological niche (factor C2bii, supplemental table S1-2). Due to the lower projected change in springflow at Comal Springs, species from this site were scored as increase to somewhat increase for hydrological niche (factor C2bii, table S1-2). Where data were available that linked increased water temperature to decreasing springflow, and thermal tolerances of species were narrow, those species were scored with higher vulnerability to decreasing springflow (supplemental table S1-2). For example, Etheostoma fonticola, the endangered fountain darter in Comal Springs (U.S. Fish and Wildlife Service, 1974), has very narrow thermal tolerance with an ideal water temperature of $24^{\circ} \mathrm{C}$, a decrease in reproduction above water temperatures of $26^{\circ} \mathrm{C}$, and a critical thermal maximum water temperature of $34.8^{\circ} \mathrm{C}$ (Brandt and others, 1993). Although springflow is projected to decline across all months, the declines were small, so this species' vulnerability to air-temperature change was scored with some uncertainty as greatly increase or increase (factor C2aii, supplemental table S1-2). 


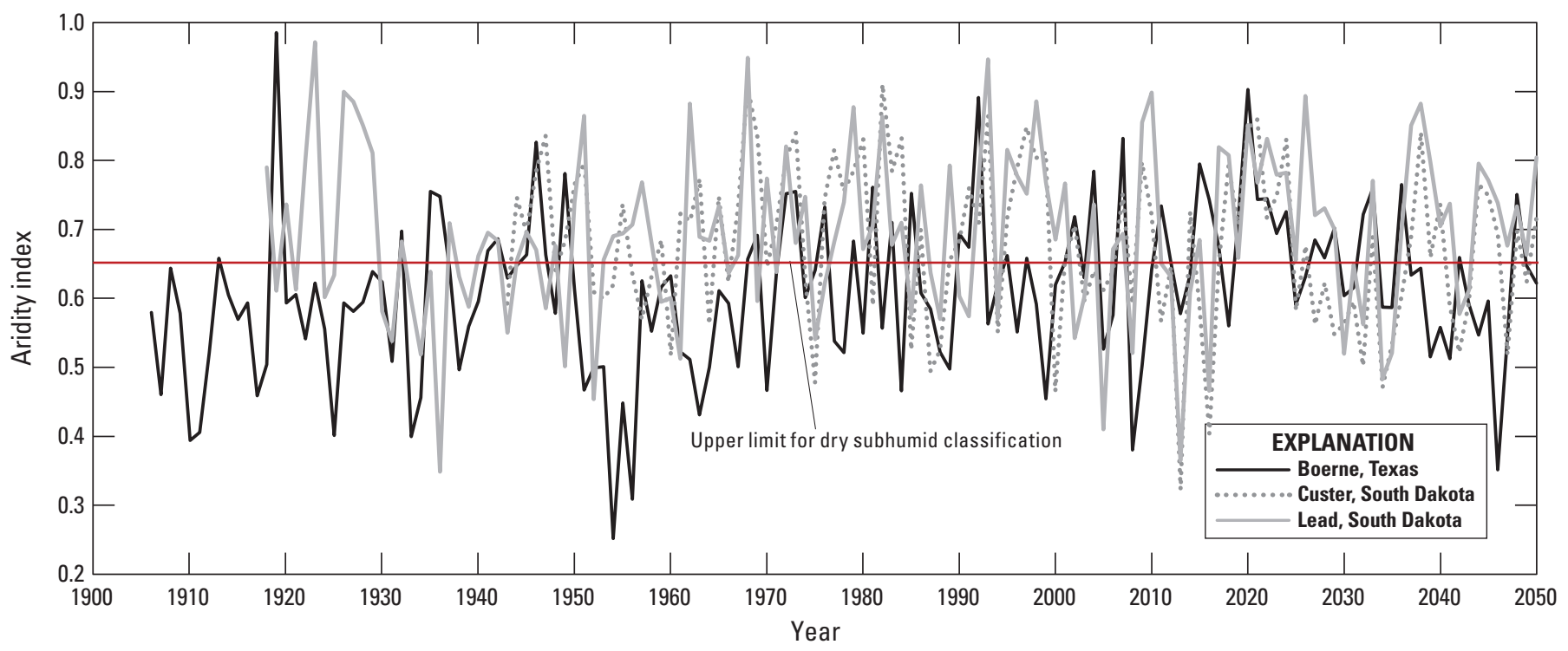

Figure 15. Aridity index for start of records through 2050 for selected weather stations.

Table 17. Percentage of years in listed time periods of aridity index classifications for weather stations for three periods: start of weather station record (SOR) to 1975, 2041-50, and SOR-2050.

[The year of the SOR changes for each station. NOAA, National Oceanic and Atmospheric Administration]

\begin{tabular}{lccccc}
\hline \multicolumn{1}{c}{ Years } & Hyperarid & Arid & Semiarid & Dry-subhumid & $\begin{array}{c}\text { Wetter than dry- } \\
\text { subhumid }\end{array}$ \\
\hline \multicolumn{5}{c}{ Boerne, Texas NOAA weather station } \\
\hline 1906-75 & 0.0 & 0.0 & 25.7 & 52.9 & 21.4 \\
2041-50 & 0.0 & 0.0 & 10.0 & 70.0 & 20.0 \\
$1906-2050$ & 0.0 & 0.0 & 16.6 & 50.3 & 33.1 \\
\hline \multicolumn{7}{c}{ Custer, South Dakota NOAA weather station } \\
\hline 1943-75 & 0.0 & 0.0 & 3.0 & 39.4 & 57.6 \\
$2041-50$ & 0.0 & 0.0 & 0.0 & 50.0 & 50.0 \\
$1943-2050$ & 0.0 & 0.0 & 6.5 & 35.2 & 58.3 \\
\hline $1918-75$ & 0.0 & 0.0 & 5.2 & 34.5 & 60.3 \\
$2041-50$ & 0.0 & 0.0 & 0.0 & 20.0 & 80.0 \\
$1918-2050$ & 0.0 & 0.0 & 5.3 & 29.3 & 65.4 \\
\hline
\end{tabular}


Table 18. Climate change vulnerability, confidence in that assessment, and vulnerability to other anthropogenic threats (as estimated by Natural Heritage rank) for selected karst-hydrology-dependent species in the Balcones Escarpment and Black Hills regions.

[National Oceanic and Atmospheric Administration (NOAA) weather station records and simulated springflow or water-table level at aquifer sites used for evaluating climate change vulnerability are in the second column. Natural Heritage ranks provide a measure of species or subspecific taxon ("T", subspecies or varieties) vulnerability to anthropogenic threats other than climate change on two spatial scales: S, state; G, global. Natural Heritage rankings of species vulnerability are: 1, critically imperiled; 2, imperiled; 3 , vulnerable; 4, apparently secure; 5, secure; ?, inexact numeric rank; SNR, state conservation status not yet assessed; Q, questionable taxonomy that may reduce conservation priority]

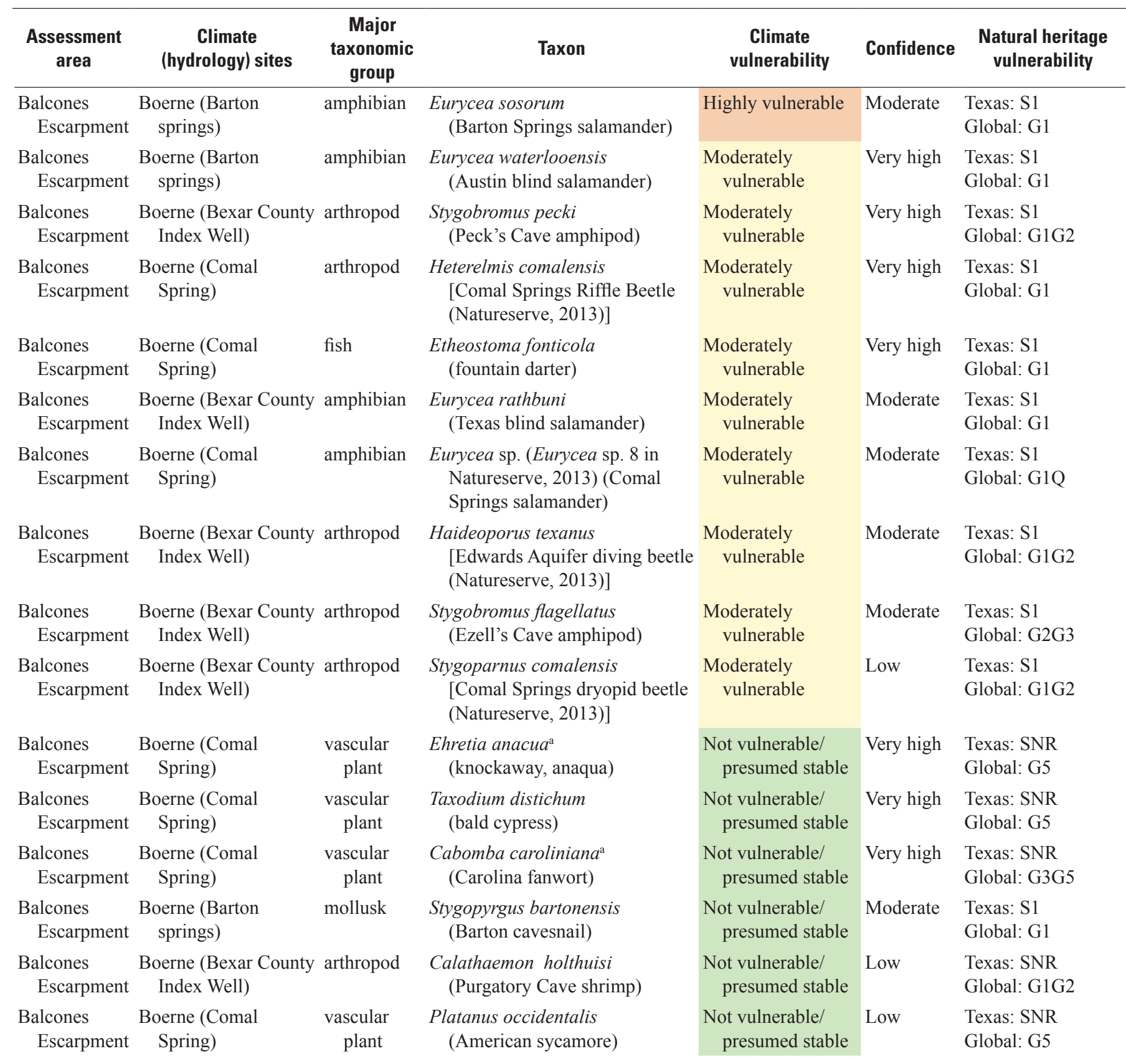


Table 18. Climate change vulnerability, confidence in that assessment, and vulnerability to other anthropogenic threats (as estimated by Natural Heritage rank) for selected karst-hydrology-dependent species in the Balcones Escarpment and Black Hills regions.-Continued

[National Oceanic and Atmospheric Administration (NOAA) weather station records and simulated springflow or water-table level at aquifer sites used for evaluating climate change vulnerability are in the second column. Natural Heritage ranks provide a measure of species or subspecific taxon ("T", subspecies or varieties) vulnerability to anthropogenic threats other than climate change on two spatial scales: S, state; G, global. Natural Heritage rankings of species vulnerability are: 1 , critically imperiled; 2 , imperiled; 3 , vulnerable; 4 , apparently secure; 5 , secure; ?, inexact numeric rank; SNR, state conservation status not yet assessed; Q, questionable taxonomy that may reduce conservation priority]

\begin{tabular}{|c|c|c|c|c|c|c|}
\hline $\begin{array}{l}\text { Assessment } \\
\text { area }\end{array}$ & $\begin{array}{l}\text { Climate } \\
\text { (hydrology) sites }\end{array}$ & $\begin{array}{c}\text { Major } \\
\text { taxonomic } \\
\text { group } \\
\end{array}$ & Taxon & $\begin{array}{c}\text { Climate } \\
\text { vulnerability }\end{array}$ & Confidence & $\begin{array}{l}\text { Natural heritage } \\
\text { vulnerability }\end{array}$ \\
\hline Black Hills & $\begin{array}{l}\text { Lead (Spearfish } \\
\text { Creek) }\end{array}$ & bird & $\begin{array}{l}\text { Cinclus mexicanus (American } \\
\text { dipper) }\end{array}$ & $\begin{array}{l}\text { Moderately } \\
\text { vulnerable }\end{array}$ & High & $\begin{array}{l}\text { South Dakota: S2 } \\
\text { Wyoming: S4 } \\
\text { Global: G5 }\end{array}$ \\
\hline Black Hills & $\begin{array}{l}\text { Lead (Spearfish } \\
\text { Creek), Custer }\end{array}$ & $\begin{array}{l}\text { vascular } \\
\text { plant }\end{array}$ & $\begin{array}{l}\text { Cypripedium parviflorum (lesser } \\
\text { yellow lady's slipper) }\end{array}$ & $\begin{array}{l}\text { Moderately } \\
\text { vulnerable }\end{array}$ & High & $\begin{array}{l}\text { South Dakota: S3? } \\
\text { Wyoming: S2 } \\
\text { Global: G5 }\end{array}$ \\
\hline Black Hills & $\begin{array}{l}\text { Lead (Spearfish } \\
\text { Creek), compos- } \\
\text { ite (Rhoads Fork } \\
\text { Spring), Custer }\end{array}$ & $\begin{array}{l}\text { vascular } \\
\text { plant }\end{array}$ & $\begin{array}{l}\text { Equisetum scirpoides (dwarf } \\
\text { scouringrush) }\end{array}$ & $\begin{array}{l}\text { Moderately } \\
\text { vulnerable }\end{array}$ & Moderate & $\begin{array}{l}\text { South Dakota: S2 } \\
\text { Wyoming: S1 } \\
\text { Global: G5 }\end{array}$ \\
\hline Black Hills & $\begin{array}{l}\text { Composite (Rhoads } \\
\text { Fork Spring) }\end{array}$ & $\begin{array}{l}\text { vascular } \\
\text { plant }\end{array}$ & Salix serissima (autumn willow) & $\begin{array}{l}\text { Moderately } \\
\text { vulnerable }\end{array}$ & Low & $\begin{array}{l}\text { South Dakota: S1 } \\
\text { Wyoming: S1 } \\
\text { Global: G4 }\end{array}$ \\
\hline Black Hills & $\begin{array}{l}\text { Lead (Spearfish } \\
\text { Creek) }\end{array}$ & $\begin{array}{l}\text { vascular } \\
\text { plant }\end{array}$ & $\begin{array}{l}\text { Asplenium trichomanes-ramosum } \\
\text { (green spleenwort) }\end{array}$ & $\begin{array}{l}\text { Not vulnerable/ } \\
\text { presumed stable }\end{array}$ & Very High & $\begin{array}{l}\text { South Dakota: S2 } \\
\text { Wyoming: S2 } \\
\text { Global: G4 }\end{array}$ \\
\hline Black Hills & $\begin{array}{l}\text { Lead (Spearfish } \\
\text { Creek), compos- } \\
\text { ite (Rhoads Fork } \\
\text { Spring) }\end{array}$ & mollusk & $\begin{array}{l}\text { Oreohelix cooperi }^{\mathrm{b}} \\
\quad \text { (Black Hills mountainsnail) }\end{array}$ & $\begin{array}{l}\text { Not vulnerable/ } \\
\text { presumed stable }\end{array}$ & Low & $\begin{array}{l}\text { South Dakota: S2 } \\
\text { Wyoming: not rated } \\
\text { Global: G5T2T3? }\end{array}$ \\
\hline Black Hills & $\begin{array}{l}\text { Lead (Spearfish } \\
\text { Creek), compos- } \\
\text { ite (Rhoads Fork } \\
\text { Spring), Custer }\end{array}$ & mammal & $\begin{array}{l}\text { Castor canadensis } \\
\quad \text { (American beaver) }\end{array}$ & $\begin{array}{l}\text { Not vulnerable/ } \\
\text { increase likely }\end{array}$ & Low & $\begin{array}{l}\text { South Dakota: S5 } \\
\text { Wyoming: S5 } \\
\text { Global: G5 }\end{array}$ \\
\hline
\end{tabular}

a Species was selected because of its importance in providing habitat for species of conservation concern.

${ }^{b}$ Because the taxonomy of the genus Oreohelix is uncertain, $O$. cooperi often is not considered a species distinct from $O$. strigosa. We follow Weaver and others (2006) in nomenclature (that is, use O. cooperi) and in the assumption that there is only one O. cooperi taxon in the Black Hills, as opposed to the two or three proposed by others (Frest and Johannes, 2002; Chak, 2007, as cited by Tronstad and Andersen, 2011).

Differences in vulnerability scores among the four species of salamanders were determined by severity of the hydrological niche (C2bii) as determined by the RRAWFLOW model (table S1-2) and severity of the anthropological barriers (B2b). For example, the Barton Springs salamander (Eurycea sosorum) and Austin blind salamander (Eurycea waterlooensis), occur in Barton Springs, a highly altered spring system, with the largest of the four springs in the Barton Springs complex used as a municipal swimming pool. The spring hydrology has been substantially altered by dams, piped outflow, and channelization that have eliminated surface dispersal among the springs. Although salamanders could potentially disperse through the karst aquifer outside of the Barton Springs complex, that has not been demonstrated definitively (Chippindale and others, 1993, 2000). A recent study indicates gene flow may have occurred between E. sosorum and E. nana (San Marcos salamander) in the past (Chippendale, 2012); however, movement of individuals through the aquifer has yet to be demonstrated. Thus, factors relating to natural and anthropogenic dispersal barriers (factors B2a and B2b) were scored as greatly increased for these species (supplemental table S1-2). These high vulnerabilities to migration coupled with high vulnerability to hydrologic niche (C2bii) resulted in the Barton Springs salamander, Eurycea sosorum, to be scored as highly vulnerable, the highest vulnerability of any species in the study. 
Table 19. Climate and hydrologic input for factors in the Climate Change Vulnerability Index (CCVI) for each weather station/hydrologic site.

[NOAA, National Oceanic and Atmospheric Administration; ${ }^{\circ} \mathrm{C}$, degrees Celsius; --, not determined]

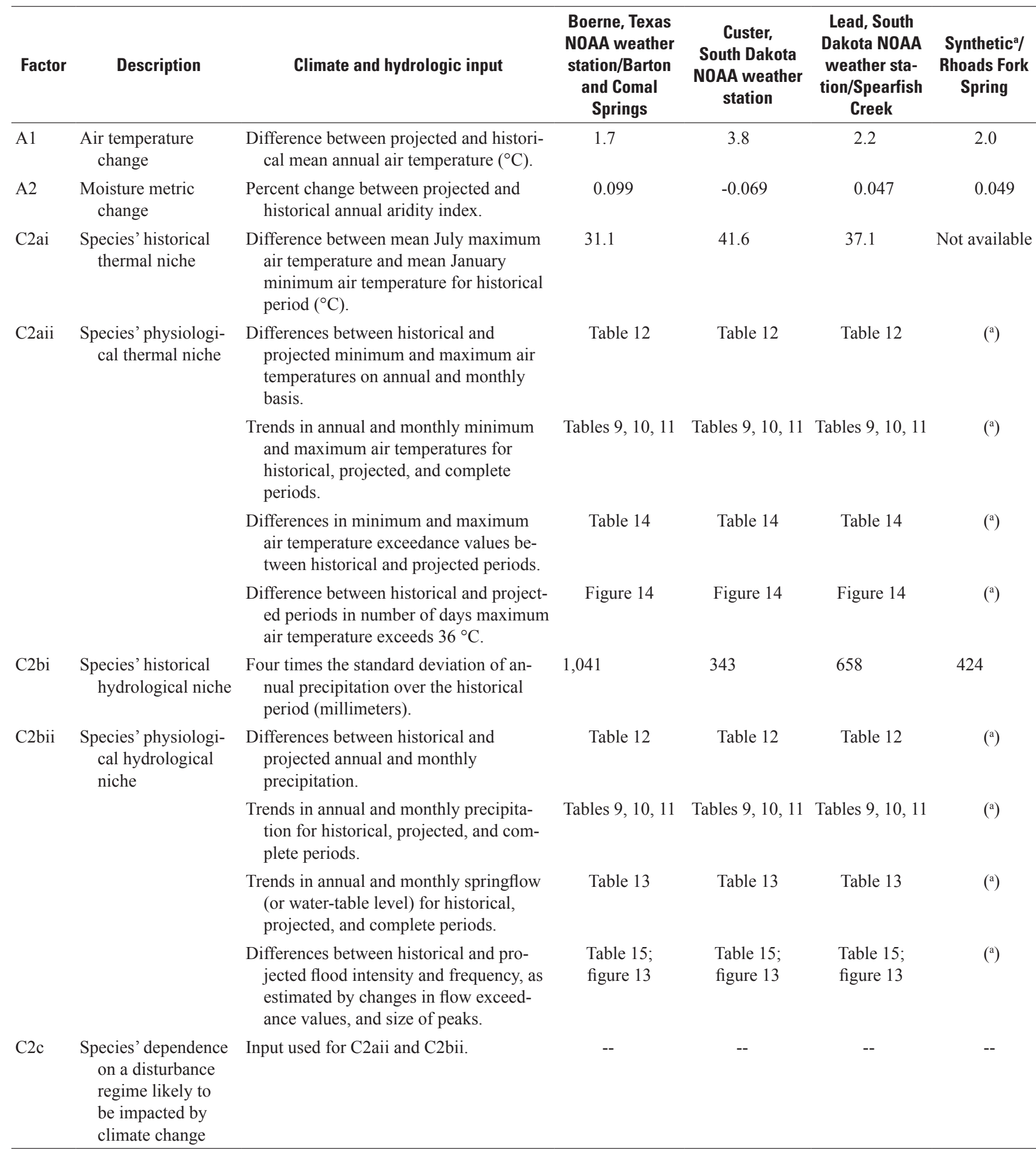

${ }^{a}$ Synthetic climate data used for Rainfall-Response Aquifer and Watershed Flow (RRAWFLOW) model input for Rhoads Fork Spring characterize climate for the north-central Black Hills. Summary information for this "station" [referred to as "Rhoads Fork (interpolated)"] is not presented, but relevant values and trends based on these data, which are shown in figure 13, are described in supplemental table S1-2. 
In contrast, Eurycea sp. 8, which was scored by the CCVI as moderately vulnerable, occurs in Comal Springs where springflow declines are projected to be less severe than in Barton Springs, and the spring systems are less hydrologically altered.

Of the four plant species scored for the Balcones Escarpment region, American sycamore (Platanus occidentalis) and bald cypress (Taxodium distichum) are relict species at their westernmost distribution, and knockaway (Ehretia anacua) and Carolina fanwort (Cabomba caroliniana) are common aquatic plants that provide important habitat for the Comal Springs riffle beetle and the fountain darter, respectively. All of the plants were scored as not vulnerable/presumed stable (table 18, supplemental table S1-2); however, confidence in the vulnerability score for $P$. occidentalis was low with 54.8 percent of Monte Carlo runs resulting in a score of not vulnerable/presumed stable whereas the remaining runs resulted in a score of moderately vulnerable (table S1-2). Previous research showed that the relict species depend on cool, moist canyons in their western distribution (Amos and Rowell, 1988) and, on the basis of their air temperature and moisture needs, Prasad and others (2007) suggested that a small increase in air temperature or decrease in springflow could lead to their extirpation in their far western distribution. Climate and hydrology were not simulated in this study for the far western part of the Balcones Escarpment, which receives substantially less annual precipitation than do the areas near Barton and Comal Springs. Expanding climate and hydrologic modeling to the sites in the western part of the Balcones Escarpment may therefore yield different climate vulnerability assessments for these species.

All of the insects and amphipods, with the exception of Heterelmis comalensis, are stygobites that are vulnerable to significant declines in aquifer level and thus scored as moderately vulnerable due to high vulnerabilities to thermal and hydrological niches (C2aii and C2bii, respectively, table S1-2). However, little biological information is available for these species so confidence in the vulnerability scores was generally low.

Of the eight species assessed for the Black Hills region, two were scored as not vulnerable/presumed stable and three as moderately vulnerable with moderate to very high confidence (table 18). The remaining three species' scores had low confidence, bordering between two ranks (one borders between not vulnerable/presumed stable and not vulnerable/ increase likely, and two border between moderately vulnerable and not vulnerable/presumed stable), as Monte Carlo simulations produced the two ranks with nearly equal frequency (supplemental table S1-2).

Climate for four of the assessed Black Hills species was represented by the Lead weather station and the interpolated weather station data relevant to Rhoads Fork Spring. For both of these weather stations, projected air temperature increases were moderate and precipitation increases substantial (table 12), yielding a positive moisture metric change, as assessed by projected (2041-50) and historical (SOR-1975) aridity index (table 19). Thus, for these species, biological factors that make them sensitive to moisture-related climate changes were generally ameliorated by low exposure to increased aridity, and biological factors that make them sensitive to heat-related climate changes were ameliorated by moderate air-temperature changes. The other four species assessed for this region have broader geographic ranges that encompass climate represented by the Custer weather station. For this weather station, the projected air temperature increase (table 12) fell into the highest category for air-temperature change exposure in the CCVI. In addition, although projected annual precipitation was higher than for the historical period, the increase was only half of that at the Lead station (table 12). Combined, these led to a projected decrease in the moisture metric (table 19) and less amelioration for heat- and moisturesensitive biological factors.

Differences in exposure to projected climate changes did not fully explain differences in species' vulnerability scores, however (table 18). Although exposed to a large mean annual $T_{\text {mean }}$ increase of $3.8^{\circ} \mathrm{C}$, the Bear Lodge meadow jumping mouse (Zapus hudsonius campestris) and American beaver (Castor canadensis) were scored as not vulnerable to climate change (table 18) because they are not restricted by high air temperatures and have broad habitat and dietary tolerances (supplemental table S1-2). The green spleenwort (Asplenium trichomanes-ramosum), a fern at the southern edge of its range whose habitat in the Black Hills is almost exclusively on vertical limestone outcrops along Spearfish Creek and one of its tributaries, was also scored as not vulnerable. Its restrictive thermal tolerance and habitat are ameliorated not only by the moderate projected climate for this habitat, but also by the high mobility of its propagules (fine, wind-blown spores) and its independence of other species and disturbance regimes.

Vulnerability scores for Black Hills mountainsnail (Oreohelix cooperi; taxonomy based on Weaver and others, 2006) and autumn willow (Salix serissima) in the Black Hills region border between not vulnerable/presumed stable and moderately vulnerable, but for different reasons. Adaptive capacity of both was reduced by their small or isolated populations and habitat specificity, and they are sensitive to high air temperatures. For the willow, these characteristics are nearly countered by its high dispersal ability (wind-blown seeds), and projected increased flow in springs like those that feed its restricted fen habitat. Only three CCVI factors were assigned more than one score, indicating uncertainty about its reliance on specific mycorrhizal symbionts and the projected climate's effect on habitat size and disturbance (fire) frequency. These opposing forces put the species' vulnerability on the border between two scores. For the snail, in contrast, seven factors had multiple scores (supplemental table S1-2). This greater uncertainty stemmed partially from more information being available for the snail than for the willow; conflicting statements within or among publications indicated different vulnerability scores (Weaver and others, 2006; Tronstad and Anderson, 2011). 
The four most vulnerable species for the Black Hills were scored as moderately vulnerable (table 18). Adaptive capacity of the American dipper (Cinclus mexicanus) and dwarf scouringrush (Equisetum scirpoides) are hampered by their low population sizes and the lack of appropriate habitat to which they can migrate (presumably following air temperature changes) within or near the Black Hills. Tolerance for high air temperatures was known (dipper) or presumed (scouringrush) to be low based on their physiology or current distribution (respectively). For example, the increased frequency of days with maximum air temperatures over a thermal threshold of $36^{\circ} \mathrm{C}$ for the dipper (fig. 14) increased its vulnerability to overheating (Willson and Kingery, 2011). In contrast, the yellow lady's slipper (Cypripedium parviflorum), an orchid, was vulnerable because of its reliance on other species for pollination, habitat, and sustenance (through mycorrhizal symbionts), as well as its low dispersal ability. Both of the moderately vulnerable plants were also affected by the increased aridity in portions of their range represented by the Custer climate station (supplemental table S1-2).

The American dipper was the only Black Hills species for which the CCVI factors related to documented or simulated response to climate change (table 5) could be scored. Vulnerability based on these factors alone also was moderately vulnerable, contributing to the high confidence in this score. Other assessments using methods related but not identical to the CCVI produced similar results: medium sensitivity in the Pacific Northwest region of the United States (Case, 2009), and not at risk for climate change effects in California (Gardali and others, 2012). This is the only scored species in the Black Hills for which other climate sensitivity analyses have been published.

Climate change is only one of many anthropogenic threats to species, and species vulnerability to these other threats might or might not correspond well to their vulnerability to climate change. Among the 24 species assessed among both regions, the species most vulnerable to other threats (based on Natural Heritage rankings; NatureServe, 2013) also were more vulnerable to climate change than were other species, in that the least imperiled species were scored as not vulnerable/presumed stable (table 18); however, highly imperiled species (Natural Heritage rank 1) were scored as both moderately vulnerable and highly vulnerable to climate change.

\section{Differences Between Regions}

Of the 231 species in the region of the Balcones Escarpment that met criteria for inclusion in this study, 75 percent of the species are endemic, 25 percent are aquatic obligates, and 29 percent are stygobites (supplemental table S1-1). Conversely, of the 25 species in the Black Hills that met the criteria for inclusion, one is endemic, one is fully aquatic, and none are stygobitic. The lack of stygobitic taxa in the
Black Hills reflects the extremely low energy input into Black Hills cave systems and aquifers relative to the input that supports species in the Balcones Escarpment region. Although the microbial community of the Madison aquifer is diverse and unique, this water has microbial biomass two to three orders of magnitude lower than that of any other karst environment, aquifer, or other body of water yet examined (Barton, 2012).

The biota in the Black Hills region had no species that were scored as highly vulnerable, had 50 percent scored as moderately vulnerable, and 38 percent scored as not vulnerable/presumed stable, whereas the Balcones Escarpment biota had 6 percent as highly vulnerable species, 56 percent as moderately vulnerable species, and 38 percent as not vulnerable/presumed stable species. Although the scored species were not a random or even representative sample of the biota of either area, it is unlikely that the difference between these two karst regions would change if more species were assessed. The Balcones Escarpment species had higher vulnerability scores than those in the Black Hills because of their high levels of endemism and therefore highly restricted range, habitat, and, in some cases, thermal tolerances, as well as higher severity of projected climate change and springflow. Significantly decreased springflow and water-table level in the modeled springs and well, respectively, and more uncertainty in future municipal water needs with climate change in the Balcones Escarpment region contrasts with increased median streamflow for the part of the Black Hills where karst hydrologyassociated species are concentrated.

\section{Evaluation of the Approach}

The very detailed climate and hydrological information produced by the approach of coupling a regional climate model - the WRF model - with the RRAWFLOW model makes it possible to evaluate some factors in much more detail than with the standard CCVI approach. The high spatial resolution of the climate projections revealed differences in the magnitude of air-temperature trends within the small area of the Black Hills (factor A1, table 19), which resulted in higher air temperature exposure scores for some Black Hills species than would have been assigned with more coarse climate information. This resolution is particularly important for regions like the Black Hills and Balcones Escarpment, both of which have strong climatic gradients over relatively small distances. Detailed hydrologic response projections also affected vulnerability scores. Using only precipitation projections, the Balcones Escarpment species would have been scored in the "neutral" to "somewhat increase" categories for factors related to moisture to reflect declining precipitation during the three summer months when springflow historically is lowest; however, the RRAWFLOW model projects significant declines in springflow and water-table level in all three sites that were modeled in the Balcones Escarpment region (table 13). These data 
were key for interpreting the effect of climate change on obligate aquatic species and led to increased vulnerability scores for 12 of the 16 species assessed. Vulnerability scores for hydrologically related factors in the Balcones Escarpment increased from "neutral" or "somewhat increase" to "somewhat increase" or "increase" for 11 of the 12 obligate aquatic species, and increased to "increase" or "greatly increase" for the Barton Springs salamander (supplemental table S1-2).

For many Black Hills species, higher projected springflow compared to the historic period (table 15), which might not have been predicted solely on the basis of precipitation and air temperature data (table 12), caused vulnerability scores to be slightly lower than would have been assigned without the hydrological response information. Thus, although hydrological response information was important for assessing climate change vulnerability of species in both regions, the diversity of fully aquatic species tied to individual springs in the Balcones Escarpment region made this information more critical than in the Black Hills region.

A single climate projection and subsequent hydrological response can yield substantially different results from other climate projections, however. For example, if the climate projection in the standard protocol provided by the CCVI (Young and others, 2012) had been used, aridity changes in the Black Hills would have been in the third and fourth, and the Balcones Escarpment in the fourth, of the standard's six aridity exposure categories (with the sixth being the highest). Note that aridity exposure differs from the aridity index, previously discussed in the "Aridity Index" section. The WRF model projection put the Black Hills in the lowest category (for more restricted species) or lowest three categories and Balcones Escarpment in the lowest category for this metric. Furthermore, the WRF model air temperature exposure is similar to that of the CCVI-provided data for the Lead weather station, but higher for the Custer weather station and lower for the Boerne weather station. Additional climate modeling at the high spatial and temporal resolution provided by the WRF model, using different but appropriate AOGCM boundary conditions or greenhouse gas scenarios, would allow evaluation of the robustness of the derived species vulnerability scores.

Finally, although detailed climate and hydrological response projections were very useful for improving the assessment of karst hydrology-related species' vulnerability to climate change, the historical data needed to accurately model hydrological response as done here do not exist for many springs and streams. Variability in the response functions of karst-fed springs and streams to contemporary climate (Long and Mahler, 2013) might preclude extrapolating hydrologic response of one site with a long history of measurement to another with little data. Where data are available, however, this approach should improve assessments of karst-associated species and ecosystem vulnerability to climate change.

\section{Summary}

Karst aquifers are important groundwater resources in North America and, because of the nature of flow in karst systems, respond rapidly to climate change. Two karst aquifers, the Edwards aquifer in the Balcones Escarpment region of south-central Texas and the Madison aquifer in the Black Hills of western South Dakota, were evaluated for hydrologic response to projected climate change through 2050. Edwards aquifer sites include Barton Springs, the Bexar County Index Well, and Comal Springs. Madison aquifer sites include Spearfish Creek and Rhoads Fork Spring. Climate projections at sites were based on output from the Community Climate System Model of global climate, linked to the Weather Research and Forecasting (WRF) model of regional climate. The WRF model projections were bias adjusted to match means for 1981-2010 from weather station records, including those at Boerne, Texas, and Lead and Custer, South Dakota. The WRF model projections for 2011-50 indicate a significant upward trend in annual mean, maximum, and minimum air temperature for all weather stations and a significant downward trend in annual precipitation for the Boerne weather station.

The hydrologic response to projected climate at spring and well sites was based on the Rainfall-Response Aquifer and Watershed Flow (RRAWFLOW) model. The RRAWFLOW model uses observed or projected climate data (air temperature and precipitation) to simulate a hydrologic response. The model simulates two processes in series: the process of precipitation becoming recharge, and the transition of recharge into a hydrologic response. Projected (2011-50) annual springflow simulated by the RRAWFLOW model had a significant downward trend for Edwards aquifers sites and no trend for Madison aquifer sites. Drought equivalent to the 1950s was not projected by the WRF model for springflow at Comal Springs (Edwards aquifer site), but a general downward trend in projected springflow might reflect effects of associated projected increases in air temperature at this and other Edwards aquifer sites. Simulated annual mean water-table level of the Bexar County Index Well fell below that observed in the 1950s (192.7 meters in 1956) for simulation years 2046 and 2047.

Many biological communities and ecosystems associated with karst aquifers and terranes are extremely sensitive to changes in hydrologic conditions. Historical and projected climate trends, computed metrics such as aridity index, and output from the RRAWFLOW model were used to assess species vulnerability to projected climate based on the Climate Change Vulnerability Index.

Sixteen species associated with springs and groundwater were assessed in the Balcones Escarpment region. The Barton Springs salamander (Eurycea sosorum) was scored as highly vulnerable with moderate confidence. Nine species - three salamanders, a fountain darter (Etheostoma fonticola), three insects, and two amphipods - were scored as moderately vulnerable. The remaining six species - four vascular plants, the Barton cavesnail (Stygopyrgus bartonensis), and a cave shrimp - were scored as not vulnerable/presumed stable. 
Vulnerability of eight species associated with streams that receive springflow from the Madison aquifer in the Black Hills was assessed. Of these, the American dipper (Cinclus mexicanus) and the lesser yellow lady's slipper (Cypripedium parviflorum) were scored as moderately vulernable with high confidence. The dwarf scouringrush (Equisetum scirpoides) and autumn willow (Salix serissima) were also scored as moderately vulnerable with moderate to low confidence, respectively. Other species were scored as not vulnerable/ presumed stable or not vulnerable/increase likely. Lower vulnerability for the Black Hills species in comparison to the Balcones Escarpment species reflects lower endemicity, higher springflow than in the historical period, and high thermal tolerance of many of the species for the Black Hills region. Importantly, climate change vulnerability scores differed substantially for Edwards aquifer species when RRAWFLOW model projections for the hydrological features the species depend on were included. Scores using these projections of significant declines in springflow and watertable level led to increased vulnerability scores for 12 of the 16 species.

\section{References Cited}

Abbott, P.L., 1975, On the hydrology of the Edwards Limestone, south-central Texas: Journal of Hydrology, v. 24, p. 251-269. (Also available at $h t t p: / / d x$. doi. org/10.1016/0022-1694(75)90084-0.)

Abbott, P.L., and Woodruff, C.M., Jr., eds., 1986, The Balcones Escarpment - Geology, hydrology, ecology and social development in central Texas: Field Trip Guidebook, 1986 Geological Society of America Annual Meeting, San Antonio, Texas, $200 \mathrm{p}$.

Ahrens, C.D., 2007, Meteorology today, An introduction to weather climate and the environment (8th ed.): Stamford, Conn., Thomson Brooks/Cole, 537 p. plus appendices.

Aleinikoff, J.N., Muhs, D.R., Bettis, E.A., III, Johnson, W.C., Fanning, C.M., and Benton, Rachel, 2008, Isotopic evidence for the diversity of late Quaternary loess in Nebraska - Glaciogenic and nonglaciogenic sources: Geological Society of America Bulletin, v. 120, p. 1,362-1,377. (Also available at http://dx.doi.org/10.1130/B26222.1.)

Amos, B.B., and Gehlbach, F.R., 1988, Edwards Plateau vegetation-Plant ecological studies in central Texas: Waco, Tex., Baylor University Press, 145 p.

Amos, B.B., and Rowell, C.M., 1988, Floristic geography of woody and endemic plants, in Amos, B.B., and Gehlbach, F.R., eds., Edwards Plateau vegetation-Plant ecological studies in central Texas: Waco, Tex., Baylor University Press, p. 25-42.
Anderson, Tamara, 2002, Conservation assessment for the American dipper in the Black Hills National Forest, South Dakota and Wyoming: Custer, S. Dak., U.S. Department of Agriculture Forest Service, Black Hills National Forest, 34 p., accessed August 29, 2013, at http://www.fs.usda.gov/ Internet/FSE_DOCUMENTS/fsm9_012057.pdf.

Anderson, Tamara, 2005, Oreohelix strigosa cooperi (Cooper's Rocky Mountain snail)—A technical conservation assessment: U.S. Department of Agriculture Forest Service, Rocky Mountain Region, accessed March 13, 2013, at http://www.fs.fed.us/r2/projects/scp/assessments/ coopersrockymountainsnail.pdf.

Ashworth, J.B., and Hopkins, J., 1995, Aquifers of Texas: Texas Water Development Board Report 345, 60 p. (Also available at $h t t p: / / w w w . t w d b . s t a t e . t x . u s /$ publications/ reports/numbered_reports/doc/R345/R345Complete.pdf.)

Backlund, Doug, 2009, The American dipper, Cinclus mexicanus in the Black Hills of South Dakota-Past and present: Pierre, S. Dak., South Dakota Department of Game, Fish and Parks, accessed September 29, 2012, at http://gfp. sd.gov/wildlife/management/diversity/black-hills-americandipper.aspx.

Barker, R.A., and Ardis, A.F., 1996, Hydrogeologic framework of the Edwards-Trinity aquifer system, west-central Texas: U.S. Geological Survey Professional Paper 1421-B, 61 p. (Also available at http://pubs.er.usgs.gov/publication/ pp1421B.)

Barron, E.J., 1985, Explanations of the Tertiary global cooling trend: Palaeogeography, Palaeoclimatology, Palaeoecology, v. 50, p. 45-61. (Also available at http://dx.doi.org/10.1016/ S0031-0182(85)80005-5.)

Barton, H.A., 2012, Accessible microbial flora of the Madison aquifer - Investigations in Calcite Lake, Wind Cave, Wind Cave National Park (final report): Akron, Ohio, University of Akron, $18 \mathrm{p}$. plus figures and tables.

Bendik, N.F., 2006, Population genetics, systematics, biogeography, and evolution of the southeastern central Texas Eurycea clade Blepsimolge (Plethodontidae): Arlington, Tex., The University of Texas at Arlington, unpublished M.S. thesis, $127 \mathrm{p}$.

Berger, A., and Loutre, M.F., 1991, Insolation values for the climate of the last 10 million years: Quaternary Science Reviews, v. 10, no. 4, p. 297-317. (Also available at $h t t p: / /$ dx.doi.org/10.1016/0277-3791(91)90033-Q.)

Bertelsen, M., Windhager, S., and Simmons, M., 2010, Recommended land management for the Water Quality Protection Lands, Austin, Texas: accessed May 14, 2014, at ftp://ftp.ci.austin.tx.us/wildland/Water_Quality_Protection_Lands/Recommended\%20Land\%20Management_ Final.pdf. 
Bezanson, D., 2000, Natural vegetation types of Texas and their representation in conservation areas: Austin, Tex., The University of Texas at Austin, unpublished M.S. thesis, $215 \mathrm{p}$.

BIO-WEST, Inc., 2011, Comprehensive and critical period monitoring program to evaluate the effects of variable flow on biological resources in the Comal Springs/River aquatic ecosystem, final 2010 annual report: accessed May 15, 2013, at http://www.edwardsaquifer.org/documents/2011_ BIOWEST_ComalCriticalPeriod2010.pdf.

Blair, W.F., 1950, The biotic provinces of Texas: Texas Journal of Science, v. 2, p. 93-117.

Blasing, T.J., 2013, Recent greenhouse gas concentrations: Carbon Dioxide Information Analysis Center, accessed August 22, 2013, at http://cdiac.ornl.gov/pns/current_ghg.html.

Bomar, G.W., 1995, Texas weather (2d ed.): Austin, Tex., University of Texas Press, $287 \mathrm{p}$.

Bonner, T.H., Brandt, T.M., Fries, J.N., and Whiteside, B.G., 1998, Effects of temperature on egg production and early life stages of the fountain darter: Transactions of the American Fisheries Society, v. 127, no. 6, p. 971978. (Also available at $h t t p: / d x$.doi.org/10.1577/15488659(1998)127<0971:EOTOEP>2.0.CO;2.)

Bousman, C.B., 1998, Palaeoenvironmental change in central Texas-The palynological evidence: Plains Anthropologist, v. 43 , no. 164 , p. 201-219. (Also available at $h t t p: / / w w w$. jstor.org/stable/25669541.)

Bowles, D.E., and Arsuffi, T.L., 1993, Karst aquatic ecosystems of the Edwards Plateau region of central Texas, USA-A consideration of their importance, threats to existence, and efforts for their conservation: Aquatic Conservation, Marine and Freshwater Ecosystems, v. 3, no. 4, p. 317-329. (Also available at $h t t p: / / d x . d o i . o r g / 10.1002 /$ aqc.3270030406.)

Bradley, R.S., 1999, Paleoclimatology—Reconstructing climates of the Quaternary (2d ed.): New York, Harcourt Academic Press, 613 p.

Brahana, J.V., Thrailkill, J., Freeman, T., and Ward, W.C., 1988, Carbonate rocks, in Back, W., Rosenshein, J.S., and Seaber, P.R., eds., Hydrogeology: Boulder, Colo., Geological Society of America, The Geology of North America, v. O-2, p. 333-352.

Brandt, T.M., Graves, K.G., Berkhouse, C.S., Simon, T.P., and Whiteside, B.G., 1993, Laboratory spawning and rearing of the endangered fountain darter: The Progressive FishCulturist, v. 55, no. 3, p. 149-156. (Also available at $h t t p: / /$ dx.doi.org/10.1577/1548-8640(1993)055<0149:LSAROT> 2.3.CO;2.)
Brown, H.P., 1987, Biology of riffle beetles: Annual Review of Entomology, v. 32, p. 253-273. (Also available at http:// dx.doi.org/10.1146/annurev.en.32.010187.001345.)

Brown, P.M., 2006, Climate effects on fire regimes and tree recruitment in Black Hills ponderosa pine: Ecology, v. 87, no. 10 , p. 2,500-2,510. (Also available at $h t t p: / / d x . d o i$. org/10.1890/0012-9658(2006)87[2500:CEOFRA]2.0 .CO;2.)

Brune, Gunnar, 1981, Springs of Texas, volume 1: College Station, Tex., Texas A\&M University Press, 566 p.

Bryce, S.A., Omernik, J.M., Pater, D.A., Ulmer, M., Schaar, J., Freeouf, J., Johanson, R., Kuck, P., and Azevedo, S.H., 1996, Ecoregions of North Dakota and South Dakota (color poster with map, descriptive text, summary tables, and photographs): Reston, Va., U.S. Geological Survey (map scale $1: 1,500,00)$.

Burchett, C.R., Rettman, P.L., and Boning, C.W., 1986, The Edwards aquifer, extremely productive, but....A sole-source water supply for San Antonio and surrounding counties in south-central Texas: San Antonio, Tex., Edwards Underground Water District Report, $38 \mathrm{p}$.

Capehart, W.J., Stamm, J., and Norton, P., 2011, Representing Great Plains prairie wetland feedbacks in WRF: extended abstract, 12th Annual WRF Users Workshop, June 21-25, Boulder, Colo., accessed May 20, 2013, at http://www. mmm.ucar.edu/wrf/users/workshops/WS2011/Extended\%20 Abstracts\%202011/P75_Capehart_ExtendedAbstract_11. $p d f$.

Carter, J.M., Driscoll, D.G., Williamson, J.E., and Lindquist, V.A., 2002, Atlas of water resources in the Black Hills area, South Dakota: U.S. Geological Survey Hydrologic Investigations Atlas HA-747, 120 p. (Also available at http://pubs.usgs.gov/ha/ha747/.)

Case, Michael, 2009, Climate Change Sensitivity Database-Cinclus mexicanus: Seattle, Wash., University of Washington, accessed January 20, 2013, at http:// climatechangesensitivity.org/node/517.

Case, M.A., and Bradford, Z.R., 2009, Enhancing the trap of lady's slippers-A new technique for discovering pollinators yields new data from Cypripedium parviflorum (Orchidaceae): Botanical Journal of the Linnean Society, v. 106, no. 1, p. 1-10. (Also available at http://dx.doi.org/10.1111/ j.1095-8339.2009.00962.x.)

Chak, S., 2007, Phylogenetic relationships and population differentiation of Oreohelix landsnails in Wyoming and adjacent South Dakota: Laramie, Wyo., University of Wyoming, unpublished M.S. thesis, $75 \mathrm{p}$. 
Chapman, S.S., Bryce, S.A., Omernik, J.M., Despain, D.G., ZumBerge, J., and Conrad, M., 2004, Ecoregions of Wyoming (color poster with map, descriptive text, summary tables, and photographs): Reston, Va., U.S. Geological Survey (map scale 1:1,400,000).

Chippendale, Paul, 2008, Population genetic analysis of the Texas blind salamander, Eurycea rathbuni, Interim report: The Endangered Species Program, Texas, Grant No. TX E-78-R, 7 p., accessed May 24, 2013, at http://www.fws.gov/ southwest/federal_assistance/PDFs/PopulationGeneticAnal ysisoftheTexanBlindSalamanderTXE-78-1.pdf.

Chippendale, Paul, 2012, Status of newly discovered cave and spring salamanders (Eurycea) in southern Travis and northern Hays Counties, Final report: The Endangered Species Program, Texas, Grant No. TX E-122-R-1, 31 p., accessed November 15, 2013, at http://www.tpwd.state.tx.us/business/ grants/wildlife/section_6/projects/amphibians_reptiles/ e122_final_report.pdf.

Chippindale, P.T., Price, A.H., and Hillis, D.M., 1993, A new species of perennibranchiate salamander (Eurycea: Plethodontidae) from Austin, Tex.: Herpetologica, v. 49, no. 2, p. 248-259. (Also available at http://www.jstor.org/ stable/3892801.)

Chippindale, P.T., Price, A.H., Wiens, J.J., and Hillis, D.M., 2000, Phylogenetic relationship and systematic revision of Central Texas Hemidactyliine Plethodontid salamanders: Herpetological Monographs, v. 14, p. 1-80. (Also available at http://www.jstor.org/stable/1467045.)

Cleaveland, M.K., Votteler, T.H., Stahle, D.K., Casteel, R.C., and Banner, J.L., 2011, Extended chronology of drought in south central, southeastern and west Texas: Texas Water Journal, v. 2, no. 1, p. 54-96. (Also available at http:// journals.tdl.org/twj/index.php/twj/article/view/2049.)

Collins, W.D., Rasch, P.J., Boville, B.A., Hack, J.J., McCaa, J.R., Williamson, D.L., Kiehl, J.T., Briegleb, B., Bitz, C., Lin, S-J., Zhang, M., and Dia, Y., 2004, Description of the NCAR Community Atmosphere Model (CAM 3.0): NCAR Technical Note NCAR/TN-464+STR, 214 p., accessed August 29, 2013, at http://www.cesm.ucar.edu/models/atmcam/docs/description/description.pdf, model output downloaded June 7, 2012, at http://www.earthsystemgrid.org.

Cooke, M.J., Stern, L.A., Banner, J.L., Mack, L.E., Stafford, T.W., Jr., and Toomey, R.S., III, 2003, Precise timing and rate of massive late Quaternary soil denudation: Geology, v. 31, no. 10, p. 853-856. (Also available at http://dx.doi. org/10.1130/G19749.1.)

Cooperative Holocene Mapping Project members, 1988, Climate changes of the last 18,000 years-Observations and model simulations: Science, v. 241, no. 4869, p. 1,043-1,052. (Also available at $h t t p: / / d x . d o i . o r g / 10.1126 /$ science.241.4869.1043.)
Cooperative Research Centre for Australian Weed Management, 2003, Cabomba (Cabomba caroliniana)_Weed management guide - Weeds of national significance: Canberra, Australia, ACT, Department of the Environment and Heritage, 6 p., accessed May 23, 2013, at http:// www.environment.gov.au/biodiversity/invasive/weeds/ publications/guidelines/wons/pubs/c-caroliniana.pdf.

Correll, D.S., and Johnston, M.C., 1970, Manual of the vascular plants of Texas: Renner, Tex., Texas Research Foundation, $1,881 \mathrm{p}$.

Cryan, P.M., and Ellison, L.E., 2005, Distributional survey of the meadow jumping mouse (Zapus hudsonius) in the northern Great Plains-Trapping report, summer 2005: Fort Collins, Colo., U.S. Geological Survey Fort Collins Science Center, 45 p., accessed May 24, 2013, at http://www. fws.gov/mountain-prairie/species/mammals/preble/peer/ Cryan\%202005.pdf

Culver, D.C., Christman, M.C., Elliott, W.R., Hobbs, H.H., III, and Reddell, J.R., 2003, The North American obligate cave fauna-Regional patterns: Biodiversity and Conservation, v. 12 , no. 3, p. 441-468. (Also available at http://dx.doi. org/10.1023/A:1022425908017.)

Culver, D.C., Master, L.L., Christman, M.C., and Hobbs, H.H., III, 2000, Obligate cave fauna of the 48 contiguous United States: Conservation Biology, v. 14, no. 2, p. 386401. (Also available at http://dx.doi.org/10.1046/j.15231739.2000.99026.x.)

Curtis, J.T., 1943, Germination and seedling development in five species of Cypripedium L.: American Journal of Botany, v. 30, no. 3, p. 199-206. (Also available at http:// www.jstor.org/stable/2437240.)

Daly, C.D., Gibson, W.P., Taylor, G.H., Johnson, G.L., and Pasteris, P., 2002, A knowledge-based approach to the statistical mapping of climate: Climatic Research, v. 22, no. 2, p. 99-113. (Also available at http://dx.doi.org/10.3354/ cr022099.)

Daly, C.D., Neilson, R.P., and Phillips, D.L., 1994, A statistical-topographic model for mapping climatological precipitation over mountainous terrain: Journal of Applied Meteorology, v. 33, no. 2, p. 140-158. (Also available at http:// dx.doi.org/10.1175/1520-0450(1994)033<0140:ASTMFM> 2.0.CO;2.)

Darton, N.H., 1909, Geology and water resources of the northern portion of the Black Hills and adjoining regions in South Dakota and Wyoming: U.S. Geological Survey Professional Paper 65, 105 p. (Also available at http://pubs. er.usgs.gov/publication/pp65.)

Darton, N.H., and Paige, S., 1925, Central Black Hills folio, South Dakota: U.S. Geological Survey Atlas of the United States, Folio 219, 34 p. (Also available at http://pubs. er.usgs.gov/publication/gf219.) 
Dewitt, E., Redden, J.A., Wilson, A.B., and Buscher, D., 1986, Mineral resource potential and geology of the Black Hills National Forest, South Dakota and Wyoming: U.S. Geological Survey Bulletin 1580, 135 p. (Also available at $h t t p: / /$ pubs.er.usgs.gov/publication/b1580.)

Diamond, D.D., and Smeins, F.E., 1993, The native plant communities of the Blackland Prairie, in Sharpless, M.R., and Yelderman, J.C., eds., The Texas Blackland Prairie, land, history, and culture: Waco, Tex., Baylor University, Program for Regional Studies, p. 66-81.

Dingman, S.L., 2002, Physical hydrology (2d ed.): Upper Saddle River, N.J., Prentice Hall, 646 p.

Dowden, D.L., 1968, Population dynamics of the San Marcos Salamander, Eurycea nana: San Marcos, Tex., Southwest Texas State College, unpublished M.S. thesis, 44 p.

Downey, J.S., and Didwiddie, G.A., 1988, The regional aquifer system underlying the northern Great Plains in parts of Montana, North Dakota, South Dakota, and Wyoming Summary: U.S. Geological Survey Professional Paper 1402-A, 64 p. (Also available at http://pubs.er.usgs.gov/ publication/pp1402A.)

Driscoll, D.G., Bunkers, M.J., Carter, J.M., Stamm, J.F., and Williamson, J.E., 2010, Thunderstorms and flooding of August 17, 2007, with a context provided by a history of other large storm and flood events in the Black Hills area of South Dakota: U.S. Geological Survey Scientific Investigations Report 2010-5187, 139 p. (Also available at $h t t p: / /$ pubs.usgs.gov/sir/2010/5187/.)

Driscoll, D.G., and Carter, J.M., 2001, Hydrologic conditions and budgets for the Black Hills of South Dakota, through water year 1998: U.S. Geological Survey Water-Resources Investigations Report 01-4226, 143 p. (Also available at http://pubs.usgs.gov/wri/wri014226/.)

Driscoll, D.G., Hamade, G.R., and Kenner, S.J., 2000, Summary of precipitation data for the Black Hills area of South Dakota, water years 1931-98: U.S. Geological Survey Open-File Report 2000-329, 151 p. (Also available at http://pubs.er.usgs.gov/publication/ofr00329.)

Edwards Aquifer Research and Data Center, 2012, Threatened and endangered species in the Edwards aquifer system: San Marcos, Tex., Texas State University, accessed September 25, 2012, at http://www.eardc.txstate.edu/about/ endangered.html.

Environment Canada, 2010, The Third Generation Coupled Global Climate Model (CGCM3): Canadian Centre for Climate Modelling and Analysis, accessed March 5, 2012, at http://www.ec.gc.ca/ccmac-cccma/default. asp?lang $=E n \& n=1299529 F-1 . c o m$.)
Ethridge, J.Z., Gibson, J.R., and Nice, C.C., 2013, Cryptic diversity within and amongst spring-associated Stygobromus amphipods (Amphipoda: Crangonyctidae): Zoological Journal of the Linnean Society, v. 167, no. 2, p. 227-242. (Also available at $h t t p: / / d x$.doi.org/10.1111/j.10963642.2012.00877.x.)

Fenneman, N.M., 1931, Physiography of the western United States: New York, McGraw-Hill Book Company, 534 p.

Fertig, W., 2000a, Asplenium trichomanes-ramosum green spleenwort: Laramie, Wyo., Wyoming Natural Diversity Database, accessed March 4, 2013, at http://www.uwyo. edu/wyndd/_files/docs/reports/speciesabstracts/asplenium_ trichomanes-ramosum.pdf.

Fertig, W., 2000b, Equisetum scirpoides dwarf scouring rush: Laramie, Wyo., Wyoming Natural Diversity Database, accessed March 4, 2013, at http://www.uwyo.edu/wyndd/_ files/docs/reports/speciesabstracts/equisetum_scirpoides.pdf.

Fetter, C.W., 2001, Applied hydrogeology (4th ed.): Upper Saddle River, N.J., Prentice Hall, 598 p.

Firestone, R.B., West, A., Kennett, J.P., Becker, L., Bunch, T.E., Revay, Z.S., Schultz, P.H., Belgya, T., Kennett, D.J., Erlandson, J.M., Dickenson, O.J., Goodyear, A.C., Harris, R.S., Howard, G.A., Kloosterman, J.B., Lechler, P., Mayewski, P.A., Montgomery, J., Poreda, R., Darrah, T., Que Hee, S.S., Smith, A.R., Stich, A., Topping, W., Wittke, J.H., and Wolbach, W.S., 2007, Evidence for an extraterrestrial impact 12,900 years ago that contributed to the megafaunal extinctions and the Younger Dryas cooling: Proceedings of the National Academy of Sciences of the United States of America, v. 104, no. 41, p. 16,016-16,021. (Also available at $h t t p: / / d x$.doi.org/10.1073/ pnas.0706977104.)

Frest, T.J., and Johannes, E.J., 2002, Land snail survey of the Black Hills National Forest, South Dakota and Wyoming, Summary Report 1991-2001, Final Report Contract No. 43-67TO-8-1085: Custer, S. Dak., U.S. Forest Service, 129 p. plus tables and appendices.

Fries, J.N., 2003, Possible reproduction of the Comal Springs riffle beetle, Heterelmis comalensis (Coleoptera: Elmidae), in captivity: Entomological News, v. 114, no. 1, p. 7-9.

Froiland, S.G., 1990, Natural history of the Black Hills and Badlands: Sioux Falls, S. Dak., Augustana College Center for Western Studies, $225 \mathrm{p}$.

Gardali, T., Seavy, N.E., Digaudio, R.T., and Comrack, L.A., 2012, A climate change vulnerability assessment of California's at-risk birds: PLoS ONE, v. 7, no. 3, e29507, 13 p. (Also available at $h t t p: / / d x$.doi.org/10.1371/journal. pone.0029507.) 
Gehlbach, F.R., 1981, Mountain islands and desert seas-A natural history of the U.S.-Mexico borderlands: College Station, Tex., Texas A\&M University Press, 298 p.

Geophysical Fluid Dynamics Laboratory, 2013, CMIP3 experiments: accessed March 20, 2014, at http://nomads. gfdl.noaa.gov/CM2.X/.

Gesch, D.B., 2007, The National Elevation Dataset, in Maune, D., ed., Digital elevation model technologies and applications - The DEM users manual (2d ed.): Bethesda, Maryland, American Society for Photogrammetry and Remote Sensing, p. 99-118.

Gesch, D., Oimoen, M., Greenlee, S., Nelson, C., Steuck, M., and Tyler, D., 2002, The National Elevation Dataset: Photogrammetric Engineering and Remote Sensing, v. 68, no. 1, p. 5-11.

Gibbard, P.L., Head, M.J., Walker, M.J.C., and the Subcommission on Quaternary Stratigraphy, 2009, Formal ratification of the Quaternary System/Period and the Pleistocene Series/Epoch with a base at 2.58 Ma: Journal of Quaternary Science, v. 25, no. 2, p. 96-102. (Also available at http:// dx.doi.org/10.1002/jqs.1338.)

Gibson, J.R., Harden, S.J., and Fries, J.N., 2008, Survey and distribution of invertebrates from selected springs of the Edwards aquifer in Comal and Hays Counties, Texas: The Southwestern Naturalist, v. 53, no. 1, p. 74-84. (Also available at http://dx.doi.org/10.1894/00384909(2008)53[74:SADOIF]2.0.CO;2.)

Gillespie, J.H., 2011, Ecology and conservation of the endangered Barton Springs salamander (Eurycea sosorum): Austin, Tex., University of Texas at Austin, unpublished Ph.D. dissertation, $143 \mathrm{p}$.

Glick, P., Stin, B.A., and Edelson, N.A., eds., 2011, Scanning the conservation horizon-A guide to climate change vulnerability assessment: Washington, D.C., National Wildlife Federation, 176 p., accessed May 21, 2013, at http://www.habitat. noaa.gov/pdf/scanning_the_conservation_horizon.pdf.

Gluesenkamp, A., 2011, Typhlomolge tail tips tell tall talesPopulation studies of Eurycea rathbuni: Unpublished presentation at Eurycea Alliance meeting at San Marcos, Tex., June 10, 2011, accessed November 26, 2013, at http:// www.eahcp.org/files/admin-records/EARIP-HCP-docs/ Gluesenkamp,\%202011.pdf.

Gonzales, T.K., 2008, Conservation genetics of the Comal Springs riffle beetle (Heterelmis comalensis) populations in central Texas, with examination of molecular and morphological variation in Heterelmis sp. throughout Texas: San Marcos, Tex., Texas State University San Marcos, unpublished M.S. thesis, accessed May 24, 2013, at https://digital. library.txstate.edu/handle/10877/3118.
Graening, G.O., and Brown, A.V., 2003, Ecosystem dynamics of an Ozark cave stream: Journal of the American Water Resources Association, v. 39, no. 6, p. 1,497-1,507. (Also available at $h t t p: / / d x$.doi.org/10.1111/j.1752-1688.2003. tb04434.x.)

Great Plains Flora Association, 1986, Flora of the Great Plains: Lawrence, Kans., University Press of Kansas, 1402 p.

Gries, J.P., 1996, Roadside geology of South Dakota: Missoula, Mont., Mountain Press Publishing Company, 358 p.

Griffith, G.E., Bryce, S.A., Omernik, J.M., Comstock, J.A., Rogers, A.C., Harrison, B., Hatch, S.L., and Bezanson, D., 2004, Ecoregions of Texas (color poster with map, descriptive text, and photographs): Reston, Va., U.S. Geological Survey (map scale 1:2,500,000).

Griffiths, J.F., and Strauss, R.F., 1985, The variety of Texas weather: Weatherwise, v. 38, no. 3, p. 137-141. (Also available at http://dx.doi.org/10.1080/00431672.1985.9933301.)

Hamon, W.R., 1961, Estimating potential evapotranspiration: Journal of the Hydraulics Division, Proceedings of the American Society of Civil Engineers, v. 87, p. 107-120.

Harden, T.M., O'Connor, J.E., Driscoll, D.G., and Stamm, J.F., 2011, Flood-frequency analyses from paleoflood investigations for Spring, Rapid, Boxelder, and Elk Creeks, Black Hills, western South Dakota: U.S. Geological Survey Scientific Investigations Report 2011-5131, 136 p. (Also available at http://pubs.usgs.gov/sir/2011/5131/.)

Hardwick, P., and Gunn, J., 1993, The impact of agriculture on limestone caves, in Williams, P., ed., Karst terrainsEnvironmental changes and human impact: Catena Supplement 25, p. 235-250.

Harris, Dave, and Aldous, S.E., 1946, Beaver management in the northern Black Hills of South Dakota: Journal of Wildlife Management, v. 10, no. 4, p. 348-353. (Also available at http://www.jstor.org/stable/3796244.)

Hays, J.D., Imbrie, John, and Shackleton, N.J., 1976, Variations in the earth's orbit-Pacemaker of the ice ages: Science, v. 194, no. 4270, p. 1,121-1,132. (Also available at http://dx.doi.org/10.1126/science.194.4270.1121.)

Hershler, R., and Longley, G., 1986, Phreatic hydrobiids (Gastropoda: Prosobranchia) from the Edwards (Balcones Fault Zone) aquifer region, south-central Texas: Malacologia, v. 27 , no. 1 , p. 127-172.

Hill, E.P., 1982, Beaver, in Chapman, J.A., and Feldhamer, G.A., eds., Wild mammals of North America-Biology, management, and economics: Baltimore, Md., Johns Hopkins University Press, p. 256-281. 
Holsinger, J.R., 1967, Systematics, speciation, and distribution of the subterranean amphipod genus Stygonectes (Gammaridae): United States National Museum Bulletin, v. 259, p. 1-176.

Hornbeck, J.H., Hull Sieg, C., and Reyher, D.J., 2003, Conservation assessment for the autumn willow in the Black Hills National Forest, South Dakota and Wyoming: Custer, S. Dak., U.S. Forest Service, Black Hills National Forest, accessed March 19, 2013, at $h t t p: / / w w w . f s . f e d . u s / r m / p u b s$ other/rmrs_2003_hornbeck_j001.pdf.

Hostetler, S.W., Alder, J.R., and Allan, A.M., 2011, Dynamically downscaled climate simulations over North America-Methods, evaluation and supporting documentation for users: U.S. Geological Survey Open-File Report 2011-1238, 64 p. (Also available at http://pubs.usgs.gov/ of/2011/1238/.)

Husby, C., 2013, Biology and functional ecology of Equisetum with emphasis on the giant horsetails: The Botanical Review, v. 79, no. 2, p. 147-177. (Also available at http:// dx.doi.org/10.1007/s12229-012-9113-4.)

Imbrie, J., Hays, J.D., Martinson, D.G., McIntyre, A., Mix, A.C., Morley, J.J., Pisias, N.G., Prell, W.L., and Shackleton, N.J., 1984, The orbital theory of Pleistocene climate-Support from a revised chronology of the marine $\mathrm{d}^{18} \mathrm{O}$ record, in Berger, A.L., Imbrie, J., Hays, J.D., Kukla, G., and Saltzman B., eds., Milankovitch and climate (part 1): Dordrecht, Netherlands, D. Reidel Publishing Company, p. 269-305.

Jakeman, A.J., and Hornberger, G.M., 1993, How much complexity is warranted in a rainfall-runoff model?: Water Resources Research, v. 29, no. 8, p. 2,637-2,649. (Also available at $h t t p: / / d x$.doi.org/10.1029/93WR00877.)

Johnson, B.N., 1933, A climatological review of the Black Hills: Rapid City, S. Dak., South Dakota School of Mines and Technology, The Black Hills Engineer, 71 p.

Johnston, R.H., 1997, Hydrologic budgets of regional aquifer systems of the United States for predevelopment and development conditions: U.S. Geological Survey Professional Paper 1425, 34 p. (Also available at http://pubs.er.usgs.gov/ publication/pp1425.)

Kendall, M.G., 1938, A new measure of rank correlation: Biometrika, v. 30, no. 1-2, p. 81-93. (Also available at http://dx.doi.org/10.1093/biomet/30.1-2.81.)

Kennett, J.P, Stott, L.D., 1991, Abrupt deep-sea warming, palaeoocenaographic changes and benthic extinctions at the end of the Palaeocene: Nature, v. 353, p. 225-229. (Also available at $h t t p: / / d x$.doi.org/10.1038/353225a0.)
Kennett, D.J., Kennett, J.P., West, Allen, West, C.J., Bunch, T.E., Culleton, B.J., Erlandson, J.M., Que Hee, S.S., Johnson, J.R., Mercer, Chris, Shen, Feng, Sellers, Marilee, Stafford, T.W., Jr., Stich, Adrienne, Weaver, J.C., Wittke, J.H., and Wolbach, W.S., 2009, Shock-synthesized hexagonal diamonds in Younger Dryas boundary sediments: Proceedings of the National Academy of Sciences of the United States of America, v. 106, no. 31, p. 12,623-12,638. (Also available at $h t t p: / / d x . d o i . o r g / 10.1073 /$ pnas.0906374106.)

Kessler, M., 2010, Biogeography of ferns, in Mehltreter, K., Walker, L.R., and Sharpe, J.M., eds., Fern ecology: Cambridge, United Kingdom, Cambridge University Press, p. $22-60$.

King, T.L., Switzer, J.F., Morrison, C.L., Eackles, M.S., Young, C.C., Lubinski, B.A., and Cryan, Paul, 2006, Comprehensive genetic analyses reveal evolutionary distinction of a mouse (Zapus hudsonius preblei) proposed for delisting from the US Endangered Species Act: Molecular Ecology, v. 15, no. 14, p. 4,331-4,359. (Also available at http:// dx.doi.org/10.1111/j.1365-294X.2006.03080.x.)

Krutzsch, P.H., 1954, North American jumping mice (genus Zapus): University of Kansas Publications, Museum of Natural History, v. 8, p. 394-472.

Kukla, G.J., Bender, M.L., de Beaulieu, J.-L., Bond, G., Broecker, W.S., Cleveringa, P., Garvin, J.E., Herbert, T.D., Imbrie, J., Jouzel, J., Keigwin, L.D., Knudsen, K.-L., McManus, J.F., Merkt, J., Muhs, D.R., Müller, H., Poore, R.Z., Porter, S.C., Seret, G., Shackleton, N.J., Turner, C., Tzedakis, P.C., and Winograd, I.J., 2002, Last interglacial climates: Quaternary Research, v. 58, p. 2-13. (Also available at http://dx.doi.org/10.1006/qres.2001.2316.)

Laird, K.R., Fritz, S.C., Maasch, K.A. and Cumming, B.F., 1996, Greater drought intensity and frequency before AD 1200 in the northern Great Plains, USA: Nature, v. 384, p. 552-554. (Also available at http://dx.doi. org/10.1038/384552a0.)

Larson, G.E., and Johnson, J.R., 2007, Plants of the Black Hills and Bear Lodge Mountains (2d ed.): Brookings, S. Dak., South Dakota State University, 608 p.

Legates, D.R., and McCabe, G.J., Jr., 1999, Evaluating the use of "goodness-of-fit" measures in hydrologic and hydroclimatic model validation: Water Resources Research, v. 35, no. 1, p. 233-241. (Also available at http://dx.doi. org/10.1029/1998WR900018.)

Linam, G.W., Mayes, K.B., and Saunders, K.S., 1993, Habitat utilization and populations size estimate of fountain darters, Etheostoma fonticola, in the Comal River, Texas: Texas Journal of Science, v. 45, no. 4, p. 341-348. 
Lindgren, R.J., Dutton, A.R., Hovorka, S.D., Worthington, S.R.H., and Painter, Scott, 2004, Conceptualization and simulation of the Edwards aquifer, San Antonio region, Texas: U.S. Geological Survey Scientific Investigations Report 2004-5277, 143 p. (Also available at $h t t p: / / p u b s$. usgs.gov/sir/2004/5277/.)

Lisenbee, A.L., and DeWitt, E., 1993, Laramide evolution of the Black Hills uplift, in Snoke, A.W., Steidtmann, J.R., and Roberts, S.M., eds., Geology of Wyoming: Geological Survey of Wyoming Memoir 5, p. 374-412.

Loáiciga, H.A., Maidment, D.R., Valdes, J.B., Roos, M., and Wood, E.F., 1996, Report of the Case Study Selection Team, ASCE/USEPA Climate Change Cooperative Agreement: Reston, Va., American Society of Civil Engineers, 17 p. plus appendix.

Loáiciga, H.A., Maidment, D.R., and Valdes, J.B., 2000, Climate-change impacts in a regional karst aquifer, Texas, USA: Journal of Hydrology, v. 227, no. 1-4, p. 173-194. (Also available at $h t t p: / / d x$.doi.org/10.1016/S00221694(99)00179-1.)

Long, A.J., 2009, Hydrograph separation for karst watersheds using a two-domain rainfall-discharge model: Journal of Hydrology, v. 364, no. 3-4, p. 249-256. (Also available at http://dx.doi.org/10.1016/j.jhydrol.2008.11.001.)

Long, A.J., and Mahler, B.J., 2013, Prediction, time variance, and classification of hydraulic response to recharge in two karst aquifers: Hydrology and Earth System Sciences, v. 17, p. 281-294. (Also available at $h t t p: / / d x . d o i . o r g / 10.5194 /$ hess-17-281-2013.)

Long, K., 2000, Beavers-A wildlife handbook: Boulder, Colo., Johnson Printing, 182 p.

Longley, G., 1986, The biota of the Edwards aquifer and the implications for paleozoogeography, in Abbott, P.L., and Woodruff, C.M., Jr., eds., The Balcones Escarpment - Geology, hydrology, ecology and social development in central Texas: Field Trip Guidebook,1986 Geological Society of America Annual Meeting, San Antonio, Tex., p. 51-54.

Love, J.D., and Christiansen, A.C., 1985, Geologic map of Wyoming: U.S. Geological Survey Map WDB 904, scale 1:500,000. (Also available at http://ngmdb.usgs.gov/ Prodesc/proddesc_16366.htm.)

Lovett, Kristie, 2010, The American dipper (Cinclus mexica$n u s$ ) in the Black Hills of South Dakota: Report prepared for South Dakota Department of Game, Fish and Parks, accessed January 18, 2012, at http://gfp.sd.gov/wildlife/ management/diversity/docs/BH-dipper-six-year-monitoring. $p d f$.
Ma, Teng, Wang, Yanxin, and Guo, Qinghai, 2004, Response of carbonate aquifer to climate change in northern ChinaA case study at the Shentou karst springs: Journal of Hydrology, v. 297, no. 1-4, p. 274-284. (Also available at http://dx.doi.org/10.1016/j.jhydrol.2004.04.020.)

Mahler, B.J., and Bourgeais, R., 2013, Dissolved oxygen fluctuations in karst spring flow and implications for endemic species-Barton Springs, Edwards aquifer, Texas, USA: Journal of Hydrology, v. 505, no. 2013, p. 291-298. (Also available at $h t t p: / / d x$.doi.org/10.1016/j. jhydrol.2013.10.004.)

Mann, M.E., Zhang, Zhihua, Rutherford, Scott, Bradley, R.S., Hughes, M.K., Shindell, Drew, Ammann, Caspar, Faluvegi, Greg, and Ni, Fenbiao, 2009, Global signatures and dynamical origins of the Little Ice Age and Medieval Climate Anomaly: Science, v. 326, no. 5957, p. 1,256-1,260. (Also available at $h t t p: / / d x$.doi.org/10.1126/science.1177303.)

Manning, M.R., Edmonds, J., Emori, S., Grubler, A., Hibbard, K., Joos, F., Kainuma, M., Keeling, R.F., Kram, T., Manning, A.C., Meinshausen, M., Moss, R., Nakicenovic, N., Riahi, K., Rose, S.K., Smith, S., Swart, R., and van Vuuren, D.P., 2010, Misrepresentation of the IPCC $\mathrm{CO}_{2}$ emission scenarios: Nature Geoscience, v. 3, p. 376-377. (Also available at $h t t p: / / d x$.doi.org/10.1038/ngeo880.)

Martin, J.E., Sawyer, J.F., Fahrenbach, M.D., Tomhave, D.W., and Schulz, L.D., 2004, Geologic map of South Dakota: South Dakota Department of Environment and Natural Resources General Map 10, scale 1:500,000.

Marriott, H.J., and Faber-Langendoen, D., 2000, Riparian and wetland plant communities of the Black Hills: Minneapolis, Minn., The Nature Conservancy, Midwest Conservation Science Center and Association for Biodiversity Information, $178 \mathrm{p}$.

McDonald, D.L., Bonner, T.H., Oborny, E.L., Jr., and Brandt, T.M., 2007, Effects of fluctuating temperature and gill parasites on reproduction of the fountain darter, Etheostoma fonticola: Journal of Freshwater Ecology, v. 22, p. 311-318. (Also available at $h t t p: / / d x$.doi.org/10.1080/02705060.2007 .9665052.)

McIntosh, A.C, 1931, A botanical survey of the Black Hills of South Dakota: The Black Hills Engineer, v. 12, p. 159-276.

McKinney, D.C., and Sharp, J.M., 1995, Springflow augmentation of Comal Springs and San Marcos Springs, Texas, phase I, feasibility study: Austin, Tex., Center for Research in Water Resources, University of Texas at Austin, Technical Report 247, 92 p.

McMahan, C.A., Frye, R.G., and Brown, K.L., 1984, The vegetation types of Texas including cropland; an illustrated synopsis to accompany the map: Austin, Tex., Texas Parks and Wildlife Department, Wildlife Division, 40 p. 
Mehltreter, K., 2010, Interactions of ferns with fungi and animals, in Mehltreter, K., Walker, L.R., and Sharpe, J.M., eds., Fern ecology: Cambridge, United Kingdom, Cambridge University Press, p. 220-254.

Merz, R.W., 1965, American sycamore (Platanus occidentalis L.), in Fowells, H.A., ed., Silvics of forest trees of the United States: Washington, D.C., U.S. Department of Agriculture, Agriculture Handbook 271, p. 489-495.

Miao, Xiaodong, Mason, J.A., Swinehart, J.B., Loope, D.B., Hanson, P.R., Goble, R.J., and Liu, Xiaodong, 2007, A 10,000 year record of dune activity, dust storms, and severe drought in the central Great Plains: Geology, v. 35, no. 2, p. 119-122. (Also available at $h t t p: / / d x$.doi.org/10.1130/G23133A.1.)

Miller, G.H., Geirdóttir, A., Zhong, Y., Larsen, D.J., OttoBliesner, B.L., Holland, M.M., Bailey, D.A., Refsnider, K.A., Lehman, S.J., Southon, J.R., Anderson, C., Bjornsson, H., and Thordarson, T., 2012, Abrupt onset of the Little Ice Age triggered by volcanism and sustained by sea-ice/ocean feedbacks: Geophysical Research Letters, v. 39, no. 2, L02708, 5 p. (Also available at $h t t p: / / d x . d o i$. org/10.1029/2011GL050168.)

Muhs, D.R., and Holliday, V.T., 1995, Evidence of active dune sand on the Great Plains in the 19th century from accounts of early explorers: Quaternary Research, v. 43, no. 2, p. 198-208. (Also available at $h t t p: / / d x . d o i . o r g / 10.1006 /$ qres.1995.1020.)

Multi-Resolution Land Characteristics Consortium, 2011, National Land Cover Database 2001 (NLCD2001): accessed December 16, 2011, at http://www.mrlc.gov/ nlcd01_data.php.

Murray, J.W., and Hansen, J., 2013, Peak oil and energy independence - Myth and reality: EOS, Transactions, American Geophysical Union, v. 94, no. 28, p. 245-247. (Also available at $h t t p: / / d x$.doi.org/10.1002/2013EO280001.)

Musgrove, M., Banner, J.L., Mack, L.E., Combs, D.M., James, E.W., Cheng, H., and Edwards, R.L., 2001, Geochronology of late Pleistocene to Holocene speleothems from central Texas-Implications for regional paleoclimate: Bulletin of the Geological Society of America, v. 113, no. 12, p. 1,5321,543. (Also available at $h t t p: / / d x$.doi.org/10.1130/00167606(2001)113<1532: GOLPTH>2.0.CO;2.)

Nakićenović, N., and Swart, R., eds., 2000, Special report on emission scenarios-A special report of Working Group III of the Intergovernmental Panel on Climate Change: Cambridge, United Kingdom, Cambridge University Press, $570 \mathrm{p}$.

Nash, J.E., and Sutcliffe, J.V., 1970, River flow forecasting through conceptual models part I-A discussion of principles: Journal of Hydrology, v. 10, no. 3, p. 282-290. (Also available at $h t t p: / / d x$.doi.org/10.1016/0022-1694(70)90255-6.)
National Climatic Data Center, 2012, National Oceanic and Atmospheric Administration National Climatic Data Center: accessed June 14, 2012, at http://www.ncdc.noaa.gov.

National Climatic Data Center, 2013, Ice Core GatewayVostok ice core data: accessed January 25, 2013, at http:// www.ncdc.noaa.gov/paleo/icecore/antarctica/vostok/ vostok_data.html.

National Oceanic and Atmospheric Administration, 2013, Carbon dioxide at NOAA's Mauna Loa Observatory reaches new milestone-Tops 400 ppm: NOAA Office of Oceanic and Atmospheric Research, accessed May 28, 2013, at http://research.noaa.gov/News/NewsArchive/LatestNews/ TabId/684/ArtMID/1768/ArticleID/10061/Carbon-Dioxideat-NOAA\%e2\%80\%99s-Mauna-Loa-Observatory-reachesnew-milestone-Tops-400-ppm.aspx.

National Plant Information Network, 2013, Native plant database: Austin, Tex., Lady Bird Johnson Wildflower center at The University of Texas, accessed March 20, 2013, at http:// www.wildflower.org/plants/.

NatureServe, 2013, NatureServe Explorer-An online encyclopedia of life [web application], version 7.1: Arlington, Va., NatureServe, accessed January-March 2013, at http:// www.natureserve.org/explorer.

Nielson-Gammon, J.W., 2011, The 2011 Texas drought, a briefing packet for the Texas Legislature: Office of the State Climatologist, Texas, 43 p., accessed September 26, 2012, at $h$ ttp://climatexas.tamu.edu/index.php/news/588-the-2011texas-drought.

Nordt, L.C., Boutton, T.W., Hallmark, C.T., and Waters, M.R., 1994, Late Quaternary vegetation and climate changes in central Texas based on the isotopic composition of organic carbon: Quaternary Research, v. 41, no. 1, p. 109-120. (Also available at http://dx.doi.org/10.1006/ qres.1994.1012.)

Nordt, L.C., Boutton, T.W., Jacob, J.S., and Mandel, R.D., $2002, \mathrm{C}_{4}$ plant productivity and climate- $\mathrm{CO}_{2}$ variations in south-central Texas during the late Quaternary: Quaternary Research, v. 58, p. 182-188. (Also available at http://dx.doi. org/10.1006/qres.2002.2344.)

Norris, W.E., Jr., Grandy, P.A., and Davis, W.K., 1963, Comparative studies on the oxygen consumption of three species of neotenic salamanders as influenced by temperature, body size, and oxygen tension: Biological Bulletin, v. 125,

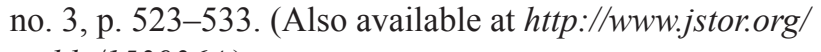
stable/1539364.)

Orgaard, Marian, 1991, The genus Cabomba (Cabombaceae) - A taxonomic study: Nordic Journal of Botany, v. 11, no. 2, p. 179-203. (Also available at http:// dx.doi.org/10.1111/j.1756-1051.1991.tb01819.x.) 
Palmer, A.N., 1990, Groundwater processes in karst terranes: Geological Society of America Special Paper 252, p. 177209.

Parsons, A.J., and Abrahams, A.D., 2009, Geomorphology of desert environments, in Parsons, A.J., and Abrahams, A.D., eds., Geomorphology of desert environments ( $2 \mathrm{~d}$ ed.): New York, Springer, p. 3-7.

Past Global Changes (PAGES) 2k Consortium, 2013, Continental-scale temperature variability during the past two millennia: Nature Geoscience, v. 6, no. 6, p. 339-346. (Also available at http://dx.doi.org/10.1038/ngeo1797.)

Peck, S.B., 1998, A summary of diversity and distribution of the obligate cave-inhabiting faunas of the United States and Canada: Journal of Cave and Karst Studies, v. 60, no. 1, p. 18-26, accessed August 29, 2013, at http://www.caves. org/pub/journal/PDF/V60/V60N1-Peck.pdf.

Peterson, A.T., 2003, Projected climate change effects on Rocky Mountain and Great Plains birds - Generalities of biodiversity consequences: Global Change Biology, v. 9, no. 5, p. 647-655. (Also available at http://dx.doi. org/10.1046/j.1365-2486.2003.00616.x.)

Petit, J.R., Jouzel, J., Raynaud, D., Barkov, N.I., Barnola, J.-M., Basile, I., Benders, M., Chappellaz, J., Davis, M., Delayque, G., Delmotte, M., Kotlyakov, V.M., Legrand, M., Lipenkov, V.Y., Lorius, C., Pépin, L., Ritz, C., Saltzman, E., and Stievenard, M., 1999, Climate and atmospheric history of the past 420,000 years from the Vostok ice core, Antarctica: Nature, v. 399, p. 429-436. (Also available at http:// dx.doi.org/10.1038/20859.)

Phillips, C.T., Wenburg, J.K., Lewis, Cara, and Olsen, Jeff, 2011, Genetic diversity in the fountain darter Etheostoma fonticola: Final report presented to the Edwards Aquifer Recovery Implementation Program Steering Committee, 45 p., accessed May 24, 2013, at http://alaska.fws.gov/ fisheries/genetics/pdf/64_RF_PhillipsWenburgLewisOlsen_ Fountain\%20darter\%20genetics\%20Report $\% 20$ 04122012\%20final.pdf.

Pinault, J.L., Plagnes, V., Aquilina, L., and Bakalowicz, M., 2001, Inverse modeling of the hydrological and the hydrochemical behavior of hydrosystems - Characterization of karst system functioning: Water Resources Research, v. 37, no. 8, p. 2,191-2,204. (Also available at http://dx.doi. org/10.1029/2001WR900018.)

Platt, S.G., Fast Horse, Zannita, Rainwater, T.R., and Miller, S.M., 2009, Distribution records and comments on mammals in western South Dakota: Western North American Naturalist, v. 69, no. 3, p. 329-334. (Also available at http:// dx.doi.org/10.3398/064.069.0306.)
Prasad, A.M., Iverson, L.R., Matthews, S., and Peters, M., 2007, A climate change atlas for 134 forest tree species of the eastern United States [database]: Delaware, Ohio, U.S. Department of Agriculture Northeast Research Station, accessed May 21, 2013, at http://www.fs.fed.us/nrs/atlas/.

Price, F.E., and Bock, C.E., 1983, Population ecology of the dipper (Cinclus mexicanus) in the Front Range of Colorado: Cooper Ornithological Society, Studies in Avian Biology No. 7, 84 p.

Raymo, M.E., Grant, B., Horowitz, M., and Rau, G.H., 1996, Mid-Pliocene warmth-Stronger greenhouse and stronger conveyor: Marine Micropaleontology, v. 27, p. 313-326. (Also available at $h t t p: / / d x$. doi.org/10.1016/03778398(95)00048-8.)

Raymo, M.E., and Rau, G., 1992, Plio-Pleistocene atmospheric $\mathrm{CO}_{2}$ levels inferred from POM d ${ }^{13} \mathrm{C}$ at SDSP Site 607: American Geophysical Union, EOS Transactions, 1992 Fall Meeting Supplement, v. 73, p. 95-96.

RECON Environmental, Inc., Hicks and Co., Zara Environmental LLC, and BIO-WEST, 2012, Edwards Aquifer Recovery Implementation Program-Habitat conservation plan: Prepared for Edwards Aquifer Recovery Implementation Program, Edwards Aquifer Authority, accessed May 21, 2013, at http://www.fws.gov/southwest/es/Documents/R2ES/ EARIP_HCP_Final_Nov_2012.pdf.

Redden, J.A., and Dewitt, E., 2008, Maps showing geology, structure, and geophysics of the central Black Hills, South Dakota: U.S. Geological Survey Scientific Investigations Map 2777, 44 p. pamphlet, 2 sheets. (Also available at http://pubs.usgs.gov/sim/2777/.)

Riskind, D.H., and Diamond, D.D., 1988, An introduction to the environments and vegetation, in Amos, B.B., and Gehlbach, F.R., eds., Edwards Plateau vegetation-Plant ecological studies in central Texas: Waco, Tex., Baylor University Press, p. 1-16.

Rose, P.R., 1972, Edwards Group, surface and subsurface, central Texas: Austin, Tex., University of Texas, Bureau of Economic Geology Report of Investigations 74, 198 p.

Ruddiman, W.F., 2010, A paleoclimate enigma?: Science, v. 328, p. 838-839. (Also available at http://dx.doi. org/10.1126/science.1188292.)

Schenck, J.R., and Whiteside, B.G., 1976, Distribution, habitat preference, and population size estimate of Etheostoma fonticola: Copeia, v. 76, no. 4, p. 697-703. (Also available at http://www.jstor.org/stable/1443451.) 
Schenck, J.R., and Whiteside, B.G., 1977, Food habits and feeding behavior of the fountain darter Etheostoma fonticola (Osteichthyes: Percidae): The Southwest Naturalist, v. 21, no. 4, p. 487-492. (Also available at $h t t p: / / w w w . j s t o r$. org/stable/30054031.)

Schorr, R.A., 2012, Using a temporal symmetry model to assess population change and recruitment in the Preble's meadow jumping mouse (Zapus hudsonius preblei): Journal of Mammalogy, v. 93, no. 5, p. 1,273-1,282. (Also available at $h t t p: / / d x$.doi.org/10.1644/11-MAMM-A-407.1.)

Schwarz, F.K., Hughes, L.A., Hansen, E.M., Petersen, M.S., and Kelly, D.B., 1975, The Black Hills-Rapid City flood of June 9-10, 1972-A description of the storm and flood: U.S. Geological Survey Professional Paper 877, 47 p. (Also available at http://pubs.er.usgs.gov/publication/pp877.)

Sharp, J.M., and Banner, J.L., 1997, The Edwards aquifer-A resource in conflict: GSA Today, v. 7, no. 8, p. 1-9.

Shefferson, R.P., Weiss, M., Kull, Tiiu, and Taylor, D.L., 2005, High specificity generally characterizes mycorrhizal association in rare lady's slipper orchids, genus Cypripedium: Molecular Ecology, v. 14, no. 2, p. 613-626. (Also available at $h t t p: / / d x$. doi.org/10.1111/j.1365-294X.2005.02424.x.)

Skamarock, W.C., Klemp, J.B., Dudhia, Jimy, Gill, D.O., Barker, D.M., Duda, M.G., Huang, X.-Y., Wang, Wie, and Powers, J.G., 2008, A description of the Advanced Research WRF version 3: NCAR Tech Note NCAR/TN-475+STR, 113 p., accessed August 26, 2013, at http://www.mmm.ucar. edu/wrf/users/docs/arw_v3.pdf.

Slade, R.M., Jr., 1986, Large rainstorms along the Balcones Escarpment in central Texas, in Abbott, P.L., and Woodruff, C.M., Jr., eds., The Balcones Escarpment-Geology, hydrology, ecology and social development in central Texas: Field Trip Guidebook, 1986 Geological Society of America Annual Meeting, San Antonio, Tex., p. 15-19.

Slade, R.M., Jr., and Patton, John, 2003, Major and catastrophic storms and floods in Texas: U.S. Geological Survey Open-File Report 03-193, no pagination, accessed August 16, 2013, at http://pubs.usgs.gov/of/2003/ofro3-193/.

Solomon, S., Qin, D., Manning, M., Chen, Z., Marquis, M., Averyt, K.B., Tignor, M., and Miller, H.L., eds., 2007, Climate change 2007-The physical science basis, Contribution of Working Group I to the Fourth Assessment Report of the Intergovernmental Panel on Climate Change: New York, Cambridge University Press, 996 p.

South Dakota Game, Fish and Parks, 2012, Threatened and endangered or rare species: accessed February 10, 2012, at http://gfp.sd.gov/wildlife/threatened-endangered/default.aspx.
Strobel, M.L., Jarrell, G.J., Sawyer, J.F., Schleicher, J.R., and Fahrenbach, M.D., 1999, Distribution of hydrogeologic units in the Black Hills area, South Dakota: U.S. Geological Survey Hydrologic Investigations Atlas HA-743, 3 sheets. (Also available at $h t t p: / / p u b s . u s g s . g o v / h a / h a 743 /$.

Sullivan, S.M.P., and Vierling, K.T., 2012, Exploring the influences of multiscale environmental factors on the American dipper Cinclus mexicanus: Ecography, v. 35, no. 7, p. 624636. (Also available at $h t t p: / / d x . d o i . o r g / 10.1111 / j .1600-$ 0587.2011.07071.x.)

Swanson, G.J., 1991, Super well is deep in the heart of Texas: Water Well Journal, no. 7, p. 56-58.

Texas Parks and Wildlife Department, 2012, Texas conservation action plan 2012-2016-Overview: Austin, Texas, Texas Conservation Action Plan Coordinator, accessed November 24, 2013, at http://www.tpwd.state.tx.us/ landwater/land/tcap/documents/tcap_overview_2012.pdf.

Texas State Historical Association, 2013, The handbook of Texas online-Droughts: accessed May 28, 2013, at http:// www.tshaonline.org/handbook/online/articles/ybd01.

The Nature Conservancy, 2008, The Edwards Plateau ecoregion: Conservation Profile TNC MRCSTX 1008, accessed May 15, 2013, at http://www.nature.org/ourinitiatives/ regions/northamerica/unitedstates/texas/placesweprotect/ edwards-plateau-fact-sheet-1008-lowres-1.pdf.

Tingley, M.W., Monahan, W.B., Beissinger, S.R., and Moritz, C., 2009, Birds track their Grinnellian niche through a century of climate change: Proceedings of the National Academy of Sciences (USA), v. 106, suppl. 2, p. 19,63719,643. (Also available at $h t t p: / / d x$.doi.org/10.1073/ pnas.0901562106.)

Toomey, R.S., III, Blum, M.D., and Valestro, Salvatore, Jr., 1993, Late Quaternary climates and environments of the Edwards Plateau, Texas: Global and Planetary Change, v. 7, no. 4, p. 299-320. (Also available at $h t t p: / / d x . d o i$. org/10.1016/0921-8181(93)90003-7.)

Tripati, A.K., Roberts, C.D., and Eagle, R.A., 2009, Coupling of $\mathrm{CO}_{2}$ and ice sheet stability over major climate transitions of the last 20 million years: Science, v. 326, no. 5958, p. 1,394-1,397. (Also available at $h t t p: / / d x$.doi.org/10.1126/ science.1178296.)

Tronstad, L.M., and Andersen, M.D., 2011, Monitoring rare land snails in the Black Hills National Forest: Report prepared by the Wyoming Natural Diversity Database, Laramie, Wyo., for the Black Hills National Forest Service, accessed March 14, 2013, at http://www.fs.usda.gov/ Internet/FSE_DOCUMENTS/stelprdb5285608.pdf. 
U.S. Department of Agriculture Forest Service, 2005, Final environmental impact statement for the Black Hills National Forest Land and Resource Management Plan Phase II Amendment: Custer, S. Dak., Black Hills National Forest, 20 p., accessed August 29, 2013, at http://www.fs.usda.gov/ Internet/FSE_DOCUMENTS/fsm9_011678.pdf.)

U.S. Department of Agriculture Forest Service, 2010, Black Hills National Forest FY 2009 Monitoring and Evaluation Report: Custer, S. Dak., Black Hills National Forest, 145 p., accessed August 29, 2013, at http://www.fs.usda.gov/ Internet/FSE_DOCUMENTS/stelprdb5262950.pdf.

U.S. Department of Agriculture Forest Service, 2012, Dippers equal a healthy habitat: accessed October 29, 2012, at http://www.fs.usda.gov/detail/blackhills/newsevents/? cid=STELPRDB5370498.

U.S. Environmental Protection Agency, 2011, Level IV ecoregions of the conterminous United States, U.S. EPA Office of Research \& Development (ORD): Corvallis, Oreg., National Health and Environmental Effects Research Laboratory (NHEERL), accessed May 21, 2013, at $h t t p: / / w w w$. epa.gov/wed/pages/ecoregions/level_iii_iv.htm\#Level IV.

U.S. Fish and Wildlife Service, 1974, Taking, possession, transportation, sale, purchase, barter, exportation, and importation of wildlife: Federal Register, v. 39, no. 3, p. $1,158-1,185$.

U.S. Fish and Wildlife Service, 1996, San Marcos and Comal Springs and associated ecosystems (Revised) recovery plan: Austin, Tex., U.S. Fish and Wildlife Service Austin Ecological Services Station, 120 p.

U.S. Fish and Wildlife Service, 2006, Endangered and threatened wildlife and plants; 90-day finding on a petition to list the Black Hills mountain snail as threatened or endangered: Federal Register, v. 71, no. 39, p. 9,988-9,999.

U.S. Fish and Wildlife Service, 2009, Part 3, Department of the Interior, Fish and Wildlife Service Endangered and threatened wildlife and plants; partial 90-day finding on a petition to list 475 species in the southwestern United States as threatened or endangered with critical habitat; proposed rule: Federal Register, v. 74, no. 240, p. 66,866-66,905.

United Nations Environment Programme, 1997, World atlas of desertification ( $2 \mathrm{~d}$ ed.): London, Edward Arnold Limited, $182 \mathrm{p}$.

University of Wyoming, 2012, Wyoming Natural Diversity Database - Species of concern: accessed February 10, 2012, at $h t t p: / / w w w . u w y o . e d u / w y n d d /$ species-of-concern/index. html.
Van Auken, O.W., 1988, Woody vegetation of the southeastern escarpment and plateau, in Amos, B.B., and Gehlbach, F.R., eds., Edwards Plateau vegetation-Plant ecological studies in central Texas: Waco, Tex., Baylor University Press, p. $43-55$.

Wagner, J.D.M., 2006, Speleothem record of southern Arizona paleoclimate, 54 to $3.5 \mathrm{ka}$ : Tucson, Ariz., University of Arizona, Ph.D. dissertation, 129 p., accessed November 27, 2013, at http://www.geo.arizona.edu/Antevs/Theses/ WagnerDiss2006.pdf.

Wang, W., Bruyère, C., Duda, M., Dudhia, J., Gill, D., Kavulich, M., Keene, K., Lin, H.-C., Michalakes, J., Rizvi, S., Zhang, X., Beezley, J.D., Coen, J.L., Mandel, J., Chuang, H.-Y., McKee, N., Slovacek, T., and Wolff, J., 2012, ARW Version 3 Modeling System User's Guide July 2012: Boulder, Colo., National Center for Atmospheric Research, Mesoscale and Microscale Meteorology Division [variously paged], accessed June 5, 2013, at http:// www.mmm.ucar.edu/wrf/users/docs/user_guide_V3/ ARWUsersGuideV3.pdf.

Waters, M.R., 1989, Late Quaternary lacustrine history and paleoclimatic significance of pluvial Lake Cochise, southeastern Arizona: Quaternary Research, v. 32, no. 1, p. 1-11. (Also available at $h t t p: / / d x$.doi.org/10.1016/00335894(89)90027-6.)

Weakly, H.E., 1943, A tree-ring record of precipitation in western Nebraska: Journal of Forestry, v. 41, no. 11, p. 816-819.

Weaver, K.F., Anderson, T., and Guralnick, R., 2006, Combining phylogenetic and ecological niche modeling approaches to determine distribution and historical biogeography of Black Hills mountain snails (Oreohelicidae): Diversity and Distributions, v. 12 , no. 6, p. 756-766. (Also available at http://www.jstor.org/stable/4124763.)

Wells, O.O., and Schmidtling, R.C., 1990, Platanus occidentalis L. sycamore, in Burns, R.M., and Honkala, B.H., technical coordinators, Silvics of North America, volume 2. Hardwoods: Washington, D.C., U.S. Department of Agriculture Forest Service, Agriculture Handbook 654, p. 511-517.

Wilhite, L.P., and Toliver, J.R., 1990, Taxodium distichum (L.) Rich. Baldcypress, in Burns, R.M., and Honkala, B.H., technical coordinators, Silvics of North America, volume 1. Conifers: Washington, D.C., U.S. Department of Agriculture Forest Service, Agriculture Handbook 654, p. 563-572.

Willson, M.F., and Kingery, H.E., 2011, American dipper (Cinclus mexicanus), in Poole, A., ed., The birds of North America online: Ithaca, N.Y., Cornell Lab of Ornithology, accessed January 20, 2013, at http://bna.birds.cornell.edu/ bna/species/229. 
Woods, H.A., Poteet, M.F., Hitchings, P.D., Brain, R.A., and Brooks, B.W., 2010, Conservation physiology of the Plethodontid salamanders Eurycea nana and E. sosorum-Response to declining dissolved oxygen: Copeia, v. 2010, no. 4, p. 540-553. (Also available at $h t t p: / / d x$. doi. org/10.1643/CP-09-026.)

Young, B., Byers, E., Gravuer, K., Hall, K., Hammerson, G., and Redder, A., 2011, Guidelines for using the NatureServe Climate Change Vulnerability Index, release 2.1: accessed September 25, 2012, at http://www.natureserve.org/sites/ default/files/publications/files/guidelines_natureserveclimat echangevulnerabilityindex_r2.1_apr2011.pdf.

Young, B.E., Hall, K.R., Byers, E., Gravuer, K., Hammerson, G., Redder, A., and Szabo, K., 2012, Rapid assessment of plant and animal vulnerability to climate change, in Brodie, J.F., Post, E.S., and Doak, D.F., eds., Wildlife conservation in a changing climate: Chicago, Ill., University of Chicago Press, p. 129-150.

Zachos, J., Pagani, M., Sloan, L., Thomas, E., and Billups, K., 2001, Trends, rhythms, and aberrations in global climate 65 Ma to present: Science, v. 292, no. 5517, p. 686-693. (Also available at $h t t p: / / d x . d o i . o r g / 10.1126 /$ science.1059412.)

Zara Environmental, 2010, Final report for the deep aquifer biota study of the Edwards aquifer, Prepared for the Edwards Aquifer Authority: 109 p., accessed May 15, 2013, at http://www.edwardsaquifer.org/documents/2010 ZaraEnvironmental_DeepAquiferBiotaStudy_Final.pdf. 


\section{Supplement 1. Data Tables for Species Vulnerability Assessment}

This supplemental section contains links to data tables (in Microsoft $囚$ Excel format) used for species vulnerability assessment. Supplemental table S1-1 lists species of conservation concern that depend strongly on karst hydrology in the Balcones Escarpment and Black Hills regions, their conservation status, restriction to the assessment area ("endemic"), and if their climate change vulnerability was scored for this report. Supplemental table S1-2 lists Climate Change Vulnerability Index (CCVI) factor scores, information supporting those scores, and the CCVI results.

Table S1-1. Species of conservation concern that depend strongly on karst hydrology in the Balcones Escarpment and Black Hills regions, their conservation status and restriction to the assessment area ("endemic"), and whether their vulnerability to climate change was scored for this report.

(http://pubs.usgs.gov/sir/2014/5089/downloads/Table_S1-1.xlsx)

Table S1-2. Climate Change Vulnerability Index (CCVI) factor scores, information supporting those scores, and the CCVI results for select karst-hydrology-dependent species in the Balcones Escarpment and Black Hills regions.

(http://pubs.usgs.gov/sir/2014/5089/downloads/Table_S1-2.xlsx)

\section{Supplement 2. Paleoclimate Inventory}

Supplemental table S2-1 (in Microsoft ${ }^{\circledR}$ Excel format) is an inventory of paleoclimate studies that are of global, regional, and local relevance.

Table S2-1. Review and inventory of local and regional paleoclimatic studies with relevance for the study areas.

(http://pubs.usgs.gov/sir/2014/5089/downloads/Table_S2-1.xlsx)

\section{Supplement 3. Weather Research and Forecasting Model Namelist Files and Bias Adjustments}

Supplemental data include input files that are used to specify a Weather Research and Forecasting (WRF) model run and annual and monthly bias adjustments to WRF output. The supplemental data text file "namelist.wps" (http://pubs.usgs.gov/ sir/2014/5089/downloads/namelist.wps) is associated with the WRF Preprocessing System and sets the model extent, grid spacing, projection, vegetation and land type maps, and soil parameters. The supplemental data text file "namelist.input" (http:// pubs.usgs.gov/sir/2014/5089/downloads/namelist.input) file re-specifies the model extent and grid spacing, defines the model computation and data-output time steps, sets physics options, and sets other parameters such as those related to boundary conditions. The namelist.input file is provided for the first 73-day increment used in the simulation of 2001-50 climate (simulation starting on August 8, 2000; note that output preceding October 1, 2000 was not used for analyses). Python scripts were used to adjust parameters in this file for incremental 73-day simulations extending to the total length of simulation (through 2050). Parameters listed in namelist files are described in the Advanced Research WRF Users Guide (Wang and others, 2012) and are summarized in the supplementary data text file "namelist.README" [(http://pubs.usgs.gov/sir/2014/5089/downloads/namelist. README) file comes bundled with source code for the WRF model, available from http://www.mmm.ucar.edu].

The WRF model output of daily precipitation was bias corrected so that the mean monthly precipitation of the daily precipitation rate for the period 1981-2010 matched that observed at the given weather station. In contrast, the WRF model output of daily mean, minimum, and maximum air temperatures were bias corrected so that the annual means of air temperatures (mean, minimum, and maximum) for the period 1981-2010 matched those observed at the given weather station. Bias correction of air temperature was computed on the basis of annual means rather than monthly means to avoid unrealistic steps in air temperature time series at the end and beginning of each month. Annual air temperature and monthly precipitation bias adjustments are listed in table S3-1. 
Table S3-1. Bias corrections applied to the Weather Research and Forecasting Model output interpolated to the locations of weather stations for modeled sites.

[IDW, inverse-distance weighting interpolation method; CCVI, Climate Change Vulnerability Index; --, bias correction not computed]

\begin{tabular}{|c|c|c|c|c|c|c|c|c|c|c|c|c|c|c|c|c|}
\hline \multirow{2}{*}{$\begin{array}{c}\text { Name of } \\
\text { modeled site }\end{array}$} & \multirow{2}{*}{$\begin{array}{l}\text { Primary weather } \\
\text { station }\end{array}$} & \multicolumn{12}{|c|}{ Precipitation bias adjustment (millimeters per day) } & \multicolumn{3}{|c|}{$\begin{array}{l}\text { Air temperature bias adjust- } \\
\text { ment (degrees Celsius) }\end{array}$} \\
\hline & & January & February & March & April & May & June & July & August & September & October & November & December & Maximum & Mean & Minimum \\
\hline \multicolumn{17}{|c|}{ Madison aquifer sites } \\
\hline $\begin{array}{l}\text { Rhoads Fork } \\
\text { Spring }\end{array}$ & $\begin{array}{l}\text { IDW of nine } \\
\text { weather stations } \mathrm{s}^{\mathrm{a}}\end{array}$ & -3.64 & -3.24 & -2.24 & -1.34 & -2.94 & -7.20 & -8.51 & -5.23 & -2.37 & 0.00 & -1.62 & -2.01 & -- & 0.81 & -- \\
\hline $\begin{array}{l}\text { Spearfish Creek } \\
\text { and CCVI site }\end{array}$ & Lead & -1.20 & -0.71 & 1.01 & 1.91 & -0.35 & -7.24 & -8.47 & -6.50 & -1.87 & 2.97 & 0.21 & -0.17 & 4.10 & 3.98 & 2.81 \\
\hline CCVI site & Custer & -0.95 & -0.01 & 0.06 & 0.51 & -1.82 & -7.76 & -7.46 & -4.18 & -1.81 & 0.34 & -0.30 & -0.28 & 1.98 & 1.32 & -0.74 \\
\hline \multicolumn{17}{|c|}{ Edwards aquifer sites } \\
\hline $\begin{array}{l}\text { Bexar County } \\
\text { Index Well }\end{array}$ & Hondo & -4.30 & -1.59 & 0.27 & -1.55 & 0.55 & 2.94 & 1.82 & 1.26 & -3.50 & 1.29 & -2.07 & -3.71 & -- & 2.00 & -- \\
\hline Barton Springs & Dripping Springs 6E & -1.30 & -1.39 & 0.53 & -2.63 & 1.16 & 4.09 & 2.03 & 1.14 & -4.78 & 1.86 & 0.00 & 1.10 & -- & 1.90 & -- \\
\hline Comal Spring & Rockspring $18 \mathrm{SW}$ & 1.67 & 2.04 & 3.13 & 0.32 & 3.20 & 7.75 & 10.31 & 6.57 & -4.66 & 4.36 & 3.57 & 2.40 & -- & 1.39 & -- \\
\hline CCVI site & Boerne & -1.98 & 0.04 & 0.88 & -1.79 & 1.44 & 4.06 & 2.92 & 2.33 & -2.64 & 2.96 & 0.90 & 0.21 & 0.96 & 0.88 & -0.76 \\
\hline
\end{tabular}

${ }^{a}$ Location is the approximate centroid of the contributing watershed.

Publishing support provided by:

Rolla and Denver Publishing Service Centers

For more information concerning this publication, contact:

Director, USGS South Dakota Water Science Center

1608 Mountain View Road

Rapid City, South Dakota 57702

(605) 394-3200

Or visit the South Dakota Water Science Center Web site at: http://sd.water.usgs.gov/ 

Back cover photographs. Upper left, Springflow at Comal Springs, Texas. Photograph by Michael Nyman, U.S. Geological Survey. Upper right, Upstream view of the U.S. Geological Survey streamgage at Rhoads Fork Spring near Rochford, South Dakota. Photograph by John Stamm, U.S. Geological Survey. 

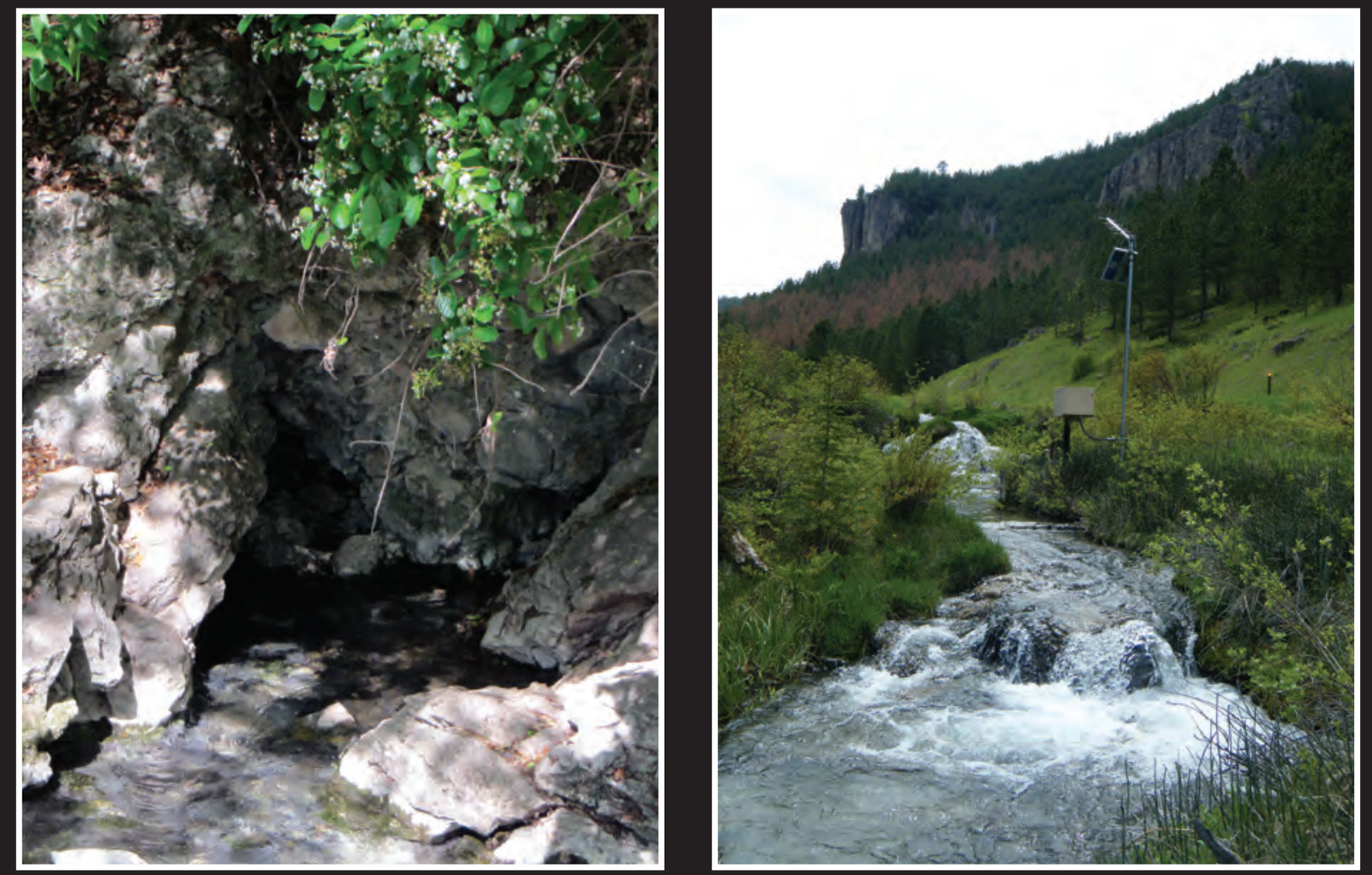

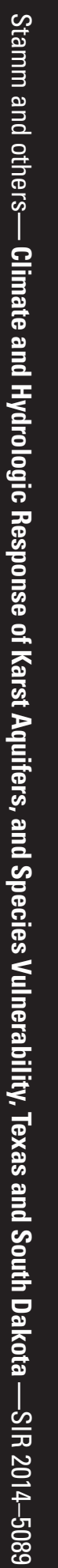

